\title{
FEDERALISM IN THE TAFT COURT ERA: CAN IT BE "REVIVED"?
}

\author{
ROBERT POST $\dagger$
}

\begin{abstract}
This Article analyzes the Supreme Court's view of federalism during the decade of the 1920s. It offers a detailed discussion of four jurisprudential areas: congressional power, dormant Commerce Clause doctrine, intergovernmental tax immunity, and judicial centralization through the enforcement of federal common law and constitutional rights. The resurgent federalism of the contemporary Court is typically characterized as "reviving" pre-New Deal principles. This Article concludes, however, that any such revival is highly implausible. It offers four reasons for this conclusion.
\end{abstract}

First, the pre-New Deal Court conceived federalism in terms of the ideal of dual sovereignty, which imagined that the federal government and the states regulated distinct and exclusive spheres of social and economic life. But because the national market had by the twentieth century become thoroughly integrated, this ideal produced doctrinal incoherence in the areas of both intergovernmental tax immunity and the dormant Commerce Clause. The application of the ideal of dual sovereignty also significantly undercut state power, because it invited the pre-New Deal Court to prohibit states from regulating the exclusively federal area of interstate commerce. For these reasons the modern Court has abandoned the ideal of dual sovereignty in its doctrine of intergovernmental tax immunity and the dormant Commerce Clause. Contemporary opinions in these areas imagine federal and state interests as intermingled and overlapping, rather than as sepa-

Copyright $\odot 2002$ by Robert Post.

i Alexander F, and May T. Morrison Professor of Law, School of Law (Boalt Hall), University of California at Berkeley. This Article was presented as the 2001 Brainerd Currie Lecture at Duke University School of Law on March 26, 2001.

Many of the sources cited within were obtained by the author from archival records. The Duke Law Joumal was thus unable to independently verify this authority. Unless otherwise noted, these sources are on file with the author. 
rated into discrete spheres. The modern view actually offers more protection for state regulations than did the ideal of dual sovereignty espoused by the pre-New Deal Court.

Second, the pre-New Deal Court understood itself as a common law court authorized to articulate the deepest experiences and values of the American people. This authority transcended the distinction between federal and state power, which is why the pre-New Deal Court never conceived itsclf as an agent of a federal government that was potentially in tension with state sovereignty. The Court never understood the centralization resulting from judicial decisionmaking as a federalism issue. The Court freely regulated intimate areas of state life through the promulgation of general common law. The pre-New Deal Court's common law authority was regarded as even more fundamental than Congress's claim to articulate the national will. The triumph of Holmesian positivism in Erie Railroad Co. v. Tompkins transformed the Court into an instrument of specifically federal law. The federalism implications of judicial decisionmaking in the areas of common law and constitutional rights were thus made manifest for the first time. The Court's authority to impose structural limitations on congressional power was also profoundly altered.

Third, the pre-New Deal Court, like the country generally, regarded the federal government as a potentially distant, bureaucratic, and oppressive institution. States were by contrast conceptualized as sites of democratic self-government. Federalism was typically conceived as the problem of "reconciling centralization with selfgovernment." Thus fedcral and state regulations, even of the same subject matter, were not regarded as equivalent. State regulation was self-chosen; federal regulation was potentially coercive. This view of the federal government was pushed to the margins of American political culture when the crisis of the New Deal legitimated the national government's authority to speak as the genuine representative of an authentic national democratic will. Combined with the demise of the Court's common law authority, this transformation of Congress's legitimacy undercut the Court's ability to second-guess Congress's vision of national priorities when reviewing the limits of congressional power.

Fourth, the pre-New Deal Court conceived structure and rights as complementary and mutually dependent concepts. The Court defined individual rights in ways designed to serve structural principles, like the integration of the national market. And it defined structural principles, like the limits of congressional power, in terms of the individ- 
ual rights affected by federal legislation. Because the Lochnerism of the pre-New Deal Court inclined it to protect freedom of contract, it sought to impose limits on congressional power that were highly sensitive to the nature of the economic transactions regulated by federal legislation. Modern constitutional thinking, by contrast, sharply distinguishes structure from rights, and it does not seek to protect the same kind of economic rights as did pre-New Deal Lochnerism.

The "revival" of pre-New Deal federalism, in short, would require the contemporary Court to restore an ideal of dual sovereignty that in important doctrinal areas is not only incoherent, but deeply antagonistic to state power; to reassert its authority as a conmon law court; to resurrect an image of Congress as a national legislature unsupported by a genuine national democratic will; and to dismantle the contemporary distinction between structure and rights so as to limit congressional power in ways designed to protect rights of substantive due process.

\section{TABLE OF CONTENTS}

Introduction

I. Federalism and the Impact of World War I: National Centralization and National Ambivalence.

II. Dual Sovereignty and the Doctrine of Intergovernmental

Tax Immunity 1526

III. Federalism and the Scope of Congressional Power ................1537

A. Congressional Power and the Commerce Clause ............1546

B. Congressional Power and the Logic of Dual Sovereignty .1558

1. Dual Sovereignty and the Form of Congressional Power.

2. Dual Sovereignty and the Substance of

Congressional Legislation 1568

C. Dual Sovereignty and the Role of the Court....................1576

IV. Federalism and National Judicial Power. .1580

A. National Judicial Power, Structure, and Individual Constitutional Rights.....................................................1580

B. Federal Common Law and Judicial Centralization ........1589 
V. Federalism and the Dormant Commerce Clause ....................1605

A. The Dormant Commerce Clause and Dual Sovereignty

B. Dual Sovereignty and the Boundary Between

Interstate and Intrastate Commerce.

C. Direct and Indirect Burdens on Interstate

Commerce

D. The Dormant Commerce Clause and Economic

Riglits

Concluding Thoughts 1634

\section{INTRODUCTION}

After decades of dormancy, federalisin lias once again become a controversial and consequential constitutional issue. Led by a Supreme Court whose "activism" is said to be directed at "reviving the structural guarantees of dual sovereignty," the current resurgence of federalism is characterized by the metaplior of resurrection. ${ }^{2}$ The pressing question seems to be whether the contemporary Court ought to resuscitate limitations on federal power that have remained quiescent simce before the New Deal.

If modern questions of federalism are to be understood as a revival of past understandings, however, it would be useful to explore the actual nature of those understandings. A good place to begin is

1. Brzonkala v. Va. Polytechnic Inst. \& State Univ., 169 F.3d 820, 893 (4th Cir. 1999) (cn banc) (Wilkinson, C.J., concurring), aff'd sub nom. United States v. Morrison, 529 U.S. 598 (2000).

2. See Jeffrey Rosen, Getting over Our Depression, N.Y. TIMES, Mar. 11, 2001, at 16 (reviewing G. EDWARD WHITE, THE CONSTITUTION AND THE NEW DEAL (2001)):

$[D]$ uring the past six years, the court has struck down all or part of morc than two dozen federal laws, on the grounds that Congress or the president had encroached on states' rights or the separation of powers. The next four years could see a redefinition of the scope of federal power through the resurrection of an aggressive role for judges in policing boundaries of national government that had been dormant since the 1930's. Whether you think this is a primcipled excrcise in constitutional restoration or a brazen display of judicial imperialism will depend on your views of the meaning of the mid-20th-century constitutional revolution that is conventionally associated with the New Deal.

See also Mark Tushnet, What Is the Supreme Court's New Federalism?, 25 OKLA. CITY U. L. REV. 927, 927 (2000) (the current Court views itself as "restorationist," seeing itself "in a position to restore the proper relation between the nation and the states" in accordance with the original constitutional vision of federahism). 
the outset of the twentieth century, when federalism was regarded by many as "the cardinal question of our constitutional system." It was even then recognized that "the balance of powers between the States and the federal government now trembles at an unstable equilibrium." That uncertain equilibrium entirely disimtegrated during the New Deal, when novel perspectives arose that radically altered hitherto traditional principles of federalism. These principles had been most comprehensively articulated in the years immediately prior to the New Deal by the Taft Court, which spanned the decade from 1921 to $1929 . .^{5}$

To study the Taft Court, therefore, is to examine the very preNew Deal federalism that the Rehnquist Court is now seemingly intent on resurrecting. It is to observe the jarring encounter between that federalism and the social and economic development of modern America. In this Article, I shall define the question of federalism as that of the constitutional distribution of power between states and the federal government, and I shall probe the strenuous efforts of the Taft Court to apply traditional understandings of federalism to the rapidly changing social realities of the early twentieth century. I hope to illuminate the nature of those understandings and to frame the question of why they collapsed so completely during the tumultuous readjustinents of the New Deal.

Traditional accounts of federalism were under particular stress throughout the decade of the 1920s. The massive centralization of World War I had destabilized older assumptions about national structure. Part I of this Article explores the confusion created by the War. Although the nation genumely appreciated the achievements made possible by federal mobilization, it also grieved for the loss of earher ideals of local self-government. The Taft Court fully participated in this national ambivalence. The Court was simultaneously cognizant of the virtues of national regulation and anxious about the loss of state authority. This ambivalence pervaded the Court's federalism jurisprudence.

3. WOODROW WILSON, CONSTITUTIONAL GOVERNMENT IN THE UNITED STATES 173 (Columbia Univ. Press 1921) (1908).

4. Id. at 191.

5. William Howard Taft was confirmed as Chief Justice on June 30,1921 . He suffered a stroke and ceased to participate in the workings of the Court in January 1930, formally resigning on February 3, 1930. For practical purposes, then, the Taft Court consists of the 1921-1928 Terms, with the addition of a short period during the $1929 \mathrm{Term}$. 
Part II discusses the difficulties that plagued traditional understandings of federalisin in the context of the Taft Court's doctrine of intergovernmental tax immunity. I shall use the phrase "dual sovereignty" to refer to these traditional understandings, because they sought to divide the country into separate and exclusive spheres of sovereignty. Dual sovereignty held that the nation and the states were each authorized to control autonomous and distinct domains of social life. The purpose of the doctrine of intergovernmental tax inmunity was to prevent federal and state governments from using their taxing powers to impinge on these distinct domains. The Taft Court sought to use the doctrine of intergovernmental tax immunity to pry apart the coinplex interdependence of state and federal governinents that World War I had made so evident. By the 1920 s, however, the nation had becoine so integrated that the Court's doctrine produced unqualified disaster.

Part III discusses the influence of dual sovereignty on the Taft Court's jurisprudence of congressional power. World War I had impressed upon the Court the undemable advantages of national control. In contexts like railroad rate regulation, the Court sustained the constitutionality of coinprehensive federal authority that effectively displaced older state regulatory institutions, thereby blurring the boundary separating distinct spheres of federal and state authority. At the same time, however, the Taft Court would in other contexts summon the logic of dual sovereignty to hmit congressional power and to safeguard an exclusive sphere of state sovereignty. The historical puzzle is why the Court balked at some forms of congressional authority, but not at others.

If the Taft Court was ambivalent about the scope of congressional authority, it was by contrast unabashedly supportive of the use of federal judicial power to sustain the national market. Although the Supreine Court had traditionally been active in this regard, the Taft Court was especially vigorous. It deployed various doctrines to achieve this end, ranging from the imposition of nationally uniform constitutional protections for property and contract, to innovative protections for foreign corporations against discrimination by state governments. The Court forcefully asserted the prerogative of the federal judiciary to articulate federal common law in cases arising under federal diversity jurisdiction. This law was highly centrahzed, es-

6. On the historical origins of dual sovereignty, see H. Jefferson Powell, The Oldest Question of Constitutional Law, 79 VA. L. REV. 633, 655-57 (1993). 
tablishing uniform legal standards that expressed the Court's perception of the prerequisites of national economic integration. It is striking that the Court never tested this judge-inade law against the logic of dual sovereignty. Part IV of this Article explores why the Court never for a moinent imagined itself as an instrument of a national government potentially threatening the integrity of distinct state spheres of sovereignty.

Part V discusses the dormant Commerce Clause, which is without doubt the most prolific, coinplex, and difficult area of the Taft Court's federalism jurisprudence. Dormant Commerce Clause doctrine focuses precisely on the intersection of state police power and the national market. The Taft Court was fundamentally confused about low it wished to conceive this relationship. On the one hand, it sought to sustain the values of dual sovereignty, carving out discrete doinains of interstate and imtrastate commerce that were meant to correspond to separate and exclusive spheres of federal and state authority. On the other hand, the Court recognized that modern economic integration lad rendered this framework of analysis hopelessly outdated and inadequate. Unguided by any clear sense of constitutional purpose, the Court's doctrme gravitated toward opaque and conclusory distinctions, like that between "direct" and "indirect" burdens on interstate commerce. The use of such doctrine facilitated highly contextual and ad hoc judginents, which frequently reflected both the nationalist bias of the Taft Court and its conservative distrust of government market regulations.

Finally, this Article concludes by exploring why the Taft Court's ideology of dual sovereignty disintegrated in the ensuing controversies of the New Deal. It presses the question of whether the contemporary Court could in any meaningful sense "revive" the federalism jurisprudence of the pre-New Deal Court.

\section{FEDERALISM AND THE IMPACT OF WORLD WAR I: NATIONAL CENTRALIZATION AND NATIONAL AMBIVALENCE}

One cannot begin to assess the Taft Court's federalism jurisprudence without appreciating the profound and pervasive influence of World War I. The "unstable equilibrium" created at the turn of the twentietl century by progressive pressure for federal reform legislation was powerfully aggravated by the war, which was, in this regard,

7. WILson, supra note 3, at 191. 
a "watershed. In 1917, the United States had to nıobilize its economy totally for the first time." wholly unprecedented intervention of the federal government in the nation's economic affairs."

By the time of the armistice the government had taken over the ocean shipping, railroad, telephone, and telegraph industries; commandeered hundreds of manufacturing plants; entered into massive economic enterprises on its own account in such varied departments as shipbuilding, wheat trading, and building construction; undertaken to lend huge sums to businesses directly or indirectly and to regulate the private issuance of securities; established official priorities for the use of transportation facilities, food, fuel, and many raw materials; fixed the prices of dozens of important commodities; intervened im hundreds of labor disputes; and conscripted millions of men for service in the armed forces.

The prosecution of the war entailed a "vast extension of centralized national authority,"11 a massive commitment to "highly centralized"12 planning, which required the country "to think and act on the scale of a nation." 13 By Noveniber 1918, the New Republic could observe that the war had produced "a great intensification of national spirit. ... We are more of a unified, self-conscious nation than ever before. Sectionahism, which not more than two years ago appeared to be a growing force in this country, has all but disappeared."14

8. Paul A.C. Koistinen, The "Industrial-Military Complex" in Historical Perspective: World War I, 41 BUS. HIST. REV. 378, 379 (1967); see also RICHARD L. WATSON, JR., THE DEVELOPMENT OF NATIONAL POWER: THE UNITED STATES, 1900-1919, at 219 (1976) (the prosecution of the war required "the most sweeping extension of national power experienced by the country up to that time").

9. Robert Higgs, CRisis and LeVIATHAN: CRITICAl EPISOdes IN THE GrowTH OF AMERICAN GOVERNMENT 123 (1987).

10. Id. For a discussion of the impact of these massive interventions on the legal sensibility of the nation, see Robert C. Post, Defending the Lifeworld: Substantive Due Process in the Taft Court Era, 78 B.U. L. REV. 1489, 1489-1505 (1998).

11. After the War-Reaction or Reconstruction, NEW REPUBLIC, Jan. 19, 1918, at 331, 332.

12. Republican Resurrection, NEW REPUBLIC, Mar. 11, 1916, at 172, 173.

13. Walter Lippinann, How to Integrate America, NEW REPUBLIC, Mar. 11, 1916, at 157, 158.

14. Nationalism and Internationalism, NEW RePUBLIC, Nov. 2, 1918, at 5, 5. "[N]ational problems and national interests are increasingly engrossing the thought of the average man. America, and America first. That is to be in the future a fundamental principle in our politics." Id.; see also Charles Hirschfeld, Nationalist Progressivism and World War I. 45 MID-AMERICA: HIST. REV. 139, 149 (1963) (describing how American society was revolutionized by increased national identification and solidarity). 
The implications of this transformation for the landscape of federalism were enormous. "In the great World War the thoughts of the entire country were turned for years to a common purpose,", ${ }^{, 15}$ recalled Attorney General Harry Daugherty:

The Government regulated our food, our fuel and our means of communication. Taxes were greatly mcreased; and because of the war Federal taxation must for years to come mean much more to the American people than ever before. It is only natural, therefore, that local government should now appear to be much less important than it was before the war and that there should be an ever-increasing tendency toward the centralization of governmental power and governmental activities in Washington. ${ }^{16}$

When during the war William Howard Taft pubhicly wondered how the Court's controversial decision in Hammer v. Dagenhart, ${ }^{17}$ which struck down the Keating-Owen Child Labor Law, could possibly have "roused public criticisin," he concluded that the "absorption of unusual governmental power at Washington under the war power of Congress makes people forget the importance of maintaining local self-government. ... [E]nthusiasts ... have no patience with constitutional restriction of Congress' power." ${ }^{19}$ Conversely, when Taft's own

15. Harry M. Daugherty, The Co-operative Duties of the States and the Federal Government, 71 U. PA. L. REV. 1,3 (1922).

16. Id. at 4; see also Horace J. Fenton, Federal Encroachments on State Rights, 22 CURRENT HIST. 613, 614 (1925):

The World War gave... tremendous emphasis [to] a strong national pride which martial and diplomatic successes have assisted not a hitle in swelling. We think in terms of the nation rather than of the States, which in the minds of many now mean little more than administrative sections of a great country.

17. 247 U.S. 251 (1918).

18. William HOWARD TAFT, Cliild-Labor Legislation, in COllected EdTORIALS, 1917-1921, at 69, 69 (James F. Vivian ed., 1990).

19. Id; see also, e.g., Raymond G. Fuller, $A$ Quest for Constitutionality, CHILD LABOR BuLl., Nov. 1918, at 207, 210:

The first child-labor laws were passed by the states because everybody used to look to the states alone for social legislation. But before this war the people were thinking nationally and were coming more and more to look to the nation for protection and the promotion of public liealth, morals and general welfare. Not only were they thinking nationally, but more things were coming to be looked upon as matters of national concern. The war has strengthened these tendencies of American thought.

At the very beginning of European hostilities, Walter Lippmann issued a prescient taunt to those who clamored for war preparedness:

What do they mean when they shout for preparedness? Are they willing to unify and socialize the railroads and the means of communication, to regulate rigorously basic industries like steel and coal mining, are they willing to control the food supply and shipping and credit, are they willing to recognize labor as a national institution?... 
subsequent decision in Bailey v. Drexel Furniture $\mathrm{Co}^{20}{ }^{20}$ striking down the child labor tax statute ${ }^{21}$ was affirmed as restoring the proper balance between federal and state governments, the decision was praised as piercing

the confusion incident to the war, with legal restraints relaxed, with the Federal Government functioning in every direction under continumg war powers, with the people accustomed during the war to look to Washington for all things as the speediest avenue of relief. It was natural for them to forget on the return of peace that their State governments were the natural channels through which their local needs were to be supplied. ${ }^{22}$

Are they ready to end the destruction of national vitality through unemployment, child labor, overwork, and poverty?

Walter Lippman, The Issues of 1916, NEW REPUBLIC, June 3, 1916, at 107, 108 (empliasis added). The force of Lippman's foresight can be seen in the fact that a month after the decision in Dagenhart, the War Labor Policies Board

adopted a resolution inaking the Secretary of Labor responsible "for the enforcement of the contract clause with reference to the employment of children by which all government contracts are to contain a clause providing that the contractor shall not directly or indirectly employ any child under the age of fourteen years, or permit any child between the ages of fourteen and sixteen to work more than eight hours in any one day, more than six days in any one week ...."

A Reprieve for Children, NEw REPUBLIC, Aug. 3,1918, at 7, 7. The New Republic observed that the Board's resolution "is only the last of a lengthening series of cases in which the executive branch of the government, responsive to prevailing public opinion and the critical needs of the nation, has found itself compelled to contravene the spirit of the law as interpreted by the Supreme Court."

The patent fact is that in matters of fundamental public policy, we are rapidly becoming a nation divided against ourselves at the fountain lieads of authority. Each executive act, however essential to the defense of the nation, that circumvents a solemn decree of the Supreine Court tends to bring not only the Supreme Court but the entire judiciary into contempt among the great masses of the people. It would secm obvious that unless there is a redefinition of authority by which the conduct of the Supreme Court is brought into harnony with the spirit of the timcs, the end of the war will find us facing domestic anarchy.

Id. at 8 . The specter of that anarcliy alarned Taft, who urged that the "conduct of the war" not become an occasion to "completely upset the balance between the federal and state governments." WILLIAM HOWARD TAFT, The Constitution in Wartime, in COLLECTED EDITORIALS, supra note 18 , at $103,105$.

20. 259 U.S. 20 (1922). Following the practice of the 1920 s, I shall sometintes refer to this case as the Child Labor Tax Case.

21. Revenue Act of 1918, Pub. L. No. 65-254, $\S \S 1200-1207,40$ Stat. 1057, 1138-40 (1919).

22. 62 CONG. REC. 7595 (1922). Although it is nnildly surprising that the liberal Brandeis jomed Taft's opinion in Bailey, see infra note 163, Stephen B. Wood interprets Brandeis's concurrence to reflect "the tremendous psychological and philosophical shock Americans (especially those attached to the Jeffersonian democratic persuasion) suffered as a result of the unprecedented centralization that was necessary to put the nation on a war footing in World War I." 
The question faced by the Court in the decade of the 1920s was how to integrate the "revolutionary changes" 23 in federal power spawned by the war into traditional understandings of federalism. ${ }^{24}$ The almost unseemly haste with which the Wilson administration disinantled the centralized regulatory apparatus of the war, ${ }^{2 s}$ together with Harding's theme of "normalcy,"26 suggest how discomforting was the prospect of any simple peacetime embrace of these transformations. ${ }^{27}$ Coolidge well expressed the national unease. While frankly acknowledging that "[o]ur generation has recently hed through times still so vivid as to seem but as yesterday, which have taught us

The immense bureaucracy, the coercive power of gathered sovereignty, and the restrictions imposed publicly and privately upon mind and expressing indelibly influenced men who were sensitive-as Brandeis and Frankfurter were-to the libertarian credo that power corrupted and paralyzed local responsibility but that a wide dispersion of pohtical and economic authority fostered democratic virtues and militated against arbitrary assaults upon individuals. There had never before been such farreaching national control, and many persons hoped it would never again be necessary.

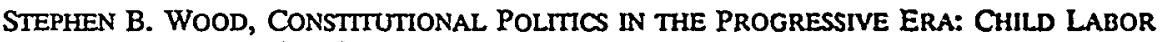
AND THE LAW 291-92 (1968).

23. After the War, supra note 11, at 331-32:

When the war is over ... the questions as to how far any one or any part of these revolutionary changes shall be permanently retained will be reconsidered.... It would, as we think, be a great mistake for the American nation to abandon any of the economic and social experiments which have been foroed on it by the exigencies of the war.

24. The Uses of an Armistice, New Republic, Nov. 16,1918 , at 59,60 ("[Reconstruction is] a change from a war to a peace structure of society. It is not a mere return to the old peace structure, which is outworn and dismantled beyond repair.").

25. Richard Hofstadter has written that Wilson "allowed his administration to close in a riot of reaction." RICHARD HOFSTADTER, THE AMERICAN POLITICAL TRADITION AND THE MEN Who MADE IT 274 (1948). See generally BURT NOGGLE, INTO THE TWENTIES: THE UNITED STATES FROM ARMISTICE TO NORMALCY (1974) (studying the transition from the Wilson presidency to the Harding presidency). By the beginning of December 1918, the Survey could observe that "[a]lready, in the short time since the armistice has been declared, there has been a noticeable lessening of that centralization of plans and of direction which is necessary to pass safely over this difficult period of change." The Carrying Fonurard of War-Time Industrial Standards, 41 SURVEY 308, 309 (1918).

26. As President Harding put it in his Inaugural Address, "[o]ur supreme task" was to resume "our onward, normal way." 61 CONG. REC. 5 (1921). "[W] must strive for normalcy to reach stability." Id.

27. If anything, this puts the point too gently. See, eg., Federalism Now Too Aggressive, AM. REV. REVIEWS, Jan. 1925, at 5:

The States in recent years have had to submit to a devastating invasion of their resources by a national Government that knows no check when the war power is invoked. No ruler or government, having once seized great and unusual splseres of authority under exceptional circumstances, is ever willing to retire to its own proper place when the emergency is passed. It is now for the citizen to decide to what extent he finds it beneficial to him to aggrandize the Government at Washington at the expense of his State Government. 
deeply to appreciate the value of union in purpose and effort," he nevertheless cautioned that the spirit of "our Federal system, distributing powers and responsibilities between the States and the National Government," imphed that "niore centrahization ought to be avoided." 28

Thoughtful assessinents of federalism throughout the 1920 s were pervasively inflected with an analogous uncertainty. On the one hand, the conduct of the war had nrade irrepressibly manifest the power and efficiency of centralized federal control, which was appreciated as necessary for survival im the dangerous world of the twentieth century. Certainly it was recognized that the war could not have been won without it. It was becoming increasmgly evident "that socially and economically the states are antiquated political areas-they are no longer social and economic units." On the other land, the "country had a surfeit of Federal administration during the war." "doctrine of state rights" was accordingly "revived and restored to the vigor of former times" during the $1920 \mathrm{~s}$. The "vast extension of the

28. Full Text of President Coolidge's Memorial Day Address at Arlington, N.Y. TIMES, May 31,1925 , at 2 [hereinafter Coolidge]. Coolidge concluded, "We must maintain a proper measure of local self-government while constantly inaking adjustments to an increasing interdependence." Id.; see also Clyde A. Beals, State Governors Challenge Federal Encroachments, 22 CURRENT HIST. 793, 793 (1925) (describing the seventeenth annual Governors' Conference, in which "President Coohidge's call for a revival of responsibility on the part of the State Governments was in every one's mind").

29. John Ely Briggs, State Rights, 10 IowA L. BuLL. 297, 308 (1925); see also Willian D. Riter, Constitutional Conceptions: A Contrast, 216 N. AM. REV. 637, 639 (1922) ("To-day there is a wide-spread feeling that the States have outgrown their usefulness. And as a necessary corollary there is an alarming tendency to insist that the Constitution be interpreted in such a way as to impose no limits on Federal activities whatever.").

30. William A. Robinson, A Constitutional Retrospect, 11 A.B.A. J. 32, 32 (1925). "Peoplo tell anecdotes about the stupidity, incompetence, or high-handedness of tax collectors. The honesty of Federal administration has been discredited by the scandalous conditions discovered in the Veterans' Bureau and the Prohibition Enforcement service." Id. at 32-33.

31. Briggs, supra note 29, at 297; see also Fenton, supra note 16, at 613 ("Many American citizens are terribly alarmed today at the prospect, as it seems to them, of the absolute extinction of State authority, government of all local affairs by bureau chiefs in Washington, the end of individual liberty and political chaos."); The Revival of Anti-Federalism, NEW REPUBLIC, Jan. 21, 1925, at 211, 212 [hereinafter Anti-Federalism]:

Since ... the passage of the Eighteenth Amendment and the experiences of the Great War, the protests against proposed increases of federal authority have become comparatively weighty and sincere.... Many intelligent and disinterested citizens are afraid that, if the process of centralizing the socializing and regulative activities of government in Washington continues, the American people will ultimately be ruled by a necessarily irresponsible federal bureaucracy which will dry up the sources of 10cal initiative and responsibility. They consider the United States too large, populous and diversified a country to be wholesomely or even safely goverued by one doininant pohtical machine. 
Federal police power"32 implicit in national prohibition, which was first introduced as a wartime measure and which liad become "associated with winning the war, ${ }^{, 33}$ remained as a standing testament to federal excess. ${ }^{34}$ It was argued that " $[t]$ he chief cause of the opposition to the Child Labor Amendment is unquestionably the reaction against the extension of Federal police control secured by the Eighteenth Amendment..335

The upshot was a messy ambivalence about issues of national authority. The Outlook, which had once been a vehicle for Theodore Roosevelt's unabashed nationalism, ${ }^{36}$ could observe that although "[t]here are few thinking men to-day who would say that, in the abstract, there should be any further centralization of power in Washington," yet "never a session of Congress passes but that some addition is inade to the bureaucracy of the National Capital." H7 Having tasted the apple of national efficiency, the nation could not easily return to the old boundaries that lad distinguished federal from state

32. Editorial, The Conference of Governors, N.Y. TIMES, July 1, 1925, at 22.

33. WALTER THOMPSON, FEDERAL CENTRALIZATION: A STUDY AND CRITICISM OF THE EXPANDING SCOPE OF CONGRESSIONAL LEGISLATION 183 (1923).

34. See Briggs, supra note 29 , at 310 :

The revolt against national prohibition has been most effective as expressed in terms of federal usurpation. A great many people who have no sympathy for intemperance and no taste for alcoholic beverages are nevertheless bitterly opposed to the Eighteenth Amendment. They regard it as a dangerous encroachment upon state rightsthe entering wedge for further imterference by the national government.

35. Edward A. Harriman, The Twilight of the States, 16 A.B.A. J. 128, 130 (1930) ("[T] he movement in favor of Federal control of matters formerly within the police power of the States reached a peak with the adoption of the Eighteenth Amendment."). There was thus a fear of "[a] Volstead child-labor law" that "would produce a legal situation similar to that respecting prohibition under the Eighteenth Amendment." Bentley W. Warren, Destroying Our "Indestructible States," 133 ATLANTIC MONTHLY 370, 374-75 (1924). In the words of John Ely Briggs:

The reaction against the increasing authority of the national government is widespread. As reflected in newspaper comment and periodical literature there seem to be two outstanding causes: first, the national control of state activities through the system of "federal aid"; and second, the character of the Eighteenth Amendment and the proposed child labor amendment.

Briggs, supra note 29, at 308-09.

36. See IRA V. BROWN, LYMAN ABBOTT 210 (1953) ("Editorials ... . left no doubt that the Outlook favored Roosevelt over Taft for the Republican nomination.... "The Roosevelt principles and The Outlook principles are the same, [Lyman] Abbot assured his friend ...." ); 3 FRANK L. MOTT, A HISTORY OF ANIERICAN MAGAZINES, 1865-1855, at 431 1-32 (1957) (noting that the Outlook "strongly favored Roosevelt editorially").

37. Coolidge, the Jeffersonian, 143 OUTLOOK 529, 530 (1926):

The piling up of board upon board, bureau upon bureau, department upon departinent in the Federal Government must come to an end, and that shortly. And, when the Federal Government once stops gobbling up the functions of the States, it will almost certainly have to regurgitate some of those it has already swallowed. 
power. "We worship Jefferson," noted one observer, "but more and more come to obey Hamilton ... because ... interests find through Federal force a potent way to carry out their plans."

This uncertainty produced anxiety and concern. Writing in 1922, for example, New York lawyer Charles W. Pierson could express the "gravest misgivings" about the "impressive phenomenon of federal encroachment upon state power." Pierson was fully aware that the "most potent" cause of this encroachinent was "internal economic development."

The invention of railways drew the different sections of the country together in a common growth, and tended to make the barriers interposed by state lines and state laws seem artificial and cumbersome. In fact, they sometimes cane to be regarded as intolerable and destructive of progress. ${ }^{41}$

Yet Pierson found these transformations profoundly distressing, despite their historical inevitability.

Are the states to be subinerged and virtually obliterated in the drift toward centralization?... The integrity of the states was a cardinal principle of our governmental scheme. Abandon that and we are adrift from the inoorings which to the minds of statesmen of past generations constituted the safety of the republic. ${ }^{42}$

It was the fate of the Taft Court to attempt to construct a jurisprudence of federalism for a country afflicted with such confusion and self-doubt. Not surprisingly, its decisions accurately reflected the ambivalent national mood.

\section{DUAL SOVEREIGNTY AND THE DOCTRINE OF INTERGOVERNMENTAL TAX IMMUNITY}

The Taft Court inherited a particular vision of federalism, which is well captured in Edward Corwin's classic description of "two mutually exclusive, reciprocally limiting fields of power, the governmental

38. See, e.g., Pleads [sic] for State Rights, N.Y. TIMES, June 19, 1923, at 3 (quoting the plen of Rep. Finis J. Garrett of Tennessee to "halt [this] mad rush toward centralizing of governmental functions and absorption by the Federal organism of governmental powers").

39. Don C. Seitz, Whence Cometh Federalism, 146 OutzooK 350, 350-51 (1927).

40. Charles W. Pierson, Our Changing CONSTITUTION 143 (1922).

41. Id. at 23.

42. Id. at 143 . 
occupants of which confront each other as equals." ${ }^{23}$ The Court concisely summarized this concept of dual sovereignty in 1905:

There are certain matters over which the National Government has absolute control, and no action of the State can interfere therewith, and there are others in which the State is supreme, and in respect to them the National Government is powerless. To preserve the even balance between these two governments and hold each in its separate sphere is the peculiar duty of all courts...."

For generations the Court had conceived the constitutional values of federalism as served by the maintenance of separate and incompatible spheres of state and federal authority. When the national "regimentation"45 accompanying World War I suddenly and unmistakably blurred the boundaries between these spheres, one response of the Taft Court was to cling all the more fiercely to its ideological inheritance. This instinct is most vividly apparent in the Taft Court's doctrine of intergovernmental tax immunity, which during the 1920s was inflated to reach "scarcely believable proportions and extensions." 46

The doctrine of intergovernmental tax immunity is unique because it presents almost purely theoretical questions of constitutional structure. It does not raise issues of laissez-faire economics or of the requirements of the national market or of the necessary protections of property. Instead it focuses cleanly and precisely on the question of how the taxation of one governmental sovereign shonld be permitted to affect the operation of another. For this reason, the Taft Court's development of the doctrine of intergovernmental tax immumity can be interpreted as expressing a vision of constitutional structure relatively undistorted by ancillary values or considerations.

Although the doctrine of intergovernmental tax immunity can in some form be traced back to the ruling of McCulloch v. Maryland, which held that Maryland could not tax the Bank of the United States, it received its first full articulation more than fifty years later

43. EdWARd CORWIN, THE COMMERCE POWER Versus STATES Rights 135 (1936). Deborah Jones Merritt writes that something like this image of federalism was "[t]he first, and oldest, of the Supreme Court's concepts of federalism." Deborah Jones Merritt, Three Faces of Federalism: Finding a Formula for the Future, 47 VAND. L REV. 1563, 1564 (1994).

44. South Carolina v. Umited States, 199 U.S. 437, 448 (1905).

45. Edward S. Corwin, The Passing of Dual Federalism, 36 U. VA. L. REv. 1, 1 (1950).

46. WIILIAM B. LOCKHART ET AL, CONSTITUTIONAL LAW: CASES-COMMENTSQUESTIONS 503 (1964).

47. 17 U.S. (4 Wheat) 316 (1819). 
in Collector v. Day, ${ }^{48}$ which held that the federal government could not tax "the means and imstrumentahities employed by [state governments] to carry into operation the powers granted" to them, and that, conversely, state governments could not tax the means and instrumentalities of the federal government. ${ }^{49}$ Day summoned an image of the "general government, and the States" as "separate and distinct sovereignties, acting separately and independently of each other, within their respective spheres." Each was "supreme" in "its appropriate sphere," 51 and mutual immumity from taxation was necessary because of "the great law of self-preservation; as any government, whose means employed in conducting its operations, if subject to the control of another and distinct government, can exist only at the mercy of that government." 52

The framework set forth by Day, which assumed that the relationship between state and federal governments was "one of tension rather than collaboration,"

48. 78 U.S. (11 Wall.) 113 (1870).

49. Id. at 127. Day differed from $M c$ Culloch because the latter had specifically reserved the question of whether the federal government could tax instrnmentahties of state governments. Marshall had strongly hinted in $\mathrm{McC}$ Culloch that federal and state governments were not symmetrically situated:

It has also been insisted, that, as the power of taxation in the general and State governments is acknowledged to be concurrent, every argument which would sustain the right of the general government to tax banks chartered by the States, will equally sustain the right of the States to tax banks chartered by the general government.

But the two cases are not on the same reason. The people of all the States have created the general government, and have conferred upon it the general power of taxation. The people of all the States, and the States themselves, are represented in Congress, and, by their representatives, exercise this power. When they tax the chartered institutions of the States, they tax their constituents; and these taxes must be uniform. But, when a State taxes the operations of the government of the United States, it acts upon institutions created, not by their own constituents, but by people over whom they claim no control. It aets upon the measures of a government created by others as well as themselves, for the benefit of others in common with themselves. The difference is that which always exists, and always must exist, between the action of the whole on a part, and the action of a part on the whole-between the laws of a government declared to be supreme, and those of a government which, when in opposition to those laws, is not supreme.

But if the full application of this argument could be admitted, it might bring into question the right of Congress to tax the State banks, and could not prove the rights of the States to tax the Bank of the United States.

McCulloch, 17 U.S. (4 Wheat.) at 435-36.

50. Day, 78 U.S. at 124.

51. Id.

52. Id. at 127.

53. Corwin, supra note 45 , at 4. 
wisdom. ${ }^{54}$ Its authority and power was such as to persuade even Holmes that states should be rigorously precluded from taxing instrumentalities of the federal government, and that this proscription ought to be enforced with greater strictness than prohibitions against state regulations of interstate commerce. As late as 1922, Holmes could observe in Gillespie v. Oklahoma ${ }^{\text {ss }}$ that

54. See, e.g., id. at 19 ("The doctrine of tax exemption was the climactic expression of the competitive theory of Federalism ...."). For a clear statement of this framework during the Taft Court era, see Missouri ex rel. Burnes Nat'l Bank v. Duncan, 265 U.S. 17, 26 (1924) (Sutherland, J., dissenting):

It is fundamental, under our dual system of government, that the Nation and the State are supreme and independent, each within its own sphere of action; and that each is exempt from the interference or control of the other in respect of its governmental powers, and the means employed in their exercise.

In Duncan, Sutherland interpreted dual sovereignty to imply an anticommandeering principle analogous to that articulated in Printz v. United States, 521 U.S. 898 (1997). Duncan concerned the validity of a federal statute requiring that national banks be authorized to serve as "executors if trust comparies competing with them have that power." 265 U.S. at 23. The Court ruled that because Missouri allowed such trust companies to act as executors, the case presented "the naked question" of "whether Congress had the power to do what it tried to do." Id. Holmes, speaking for seven Justices, held in the affirmative. Sutherland, dissenting with McReynolds, reasoned that

It is settled beyond controversy, that the right of a State to pass laws, to administer them through courts of justice, and to employ agencies for the legitimate purposes of state government cannot be taxed,... and that rule is but an application of the general and broader rule, which forbids any interference by the federal government with the governmental powers of a State. The settlement of successions to property on death is a subject within the exclusive control of the States and entirely beyond the sphere of national authority.... The duty and power of the State to provide a tribunal for the accomplishment of these ends ... it follows, cannot be abridged by federal legislation....

During the process of administration the estate, in contemplation of law, is in the custody of the court exercising probate powers, and of this court the executor or administrator is an officer....

The probate courts of a State have only such powers as the state legislature gives them. They are wholly beyond the jurisdiction of Congress, and it does not seem to me to be within the competency of that body, on any pretext, to compel such courts to appoint as executor or administrator one who the state law has declared shall not be appointed.

The particular invasion here sanctioned may not be of great moment; but it is a precedent, which, if carried to the logical extreme, would go far toward reducing the States of the Umion to the status of mere geographical subdivisions.

Id. at 27,29 .

55. 257 U.S. 501 (1922). Pituey, Clarke and Brandeis dissented without opinion. Gillespie held that the state of Oklalioma could not apply a general income tax to oil and gas revenues derived from land leased froin federally protected Indians. Holmes held for the Court that "the lessee was an instrumentakity used by the United States in carrying out duties to the Indians that it had assumed." Id. at 504. 
[t]he criterion of interference by the States with interstate commerce is one of degree. It is well understood that a certain amount of reaction upon and interference with such commerce cannot be avoided if the States are to exist and make laws. ... The rule as to instrumentalities of the United States on the other hand is absolute in form and at least stricter in substance.... "A tax upon the leases is a tax upon the power to make them, and could be used to destroy the power to make them.",56

Later in the decade, Holmes would have occasion to regret these words; ${ }^{57}$ he came to appreciate that "the criterion of interference" of state taxation on federal instrumentalities must also be conceptualized as "one of degree."

56. Id. at 505 (quoting Indian Territory Illuminating Oil Co. v. Oklahoma, 240 U.S. 522, 530 (1916) (citations omitted)).

57. Gillespie was immediately controversial. See Jaybird Mining Co. v. Weir, 271 U.S. 609, 619 (1926) (Brandeis, J., dissenting) ("I suspect that my brethren would agree with me in sustaining this tax on ore in the bins but for Gillespie.... Any language in [Gillespie] which may seem apposite to the case at bar, should be disregarded as inconsistent with the earlicr decisions."); cf. Thomas Reed Powell, The Waning of Intergovernmental Tax Immunities, 58 HARV. L. REV. 633, 641 (1945) (arguing that Gillespie should be consigned "to a merited liunbo"); Note, Constitutional Law-Taxation-Exemption of Sales Made to Federal Government from State Sales Tax, 23 ILL. L. REV. 707, 712-13 (1929):

A hiteral application of the language of the opinion in Gillespie $\nu$. United States to the ... situation [of Panhandle] might lead to the extreme result of permitting the defendant to claim exemption from state income tax upon such portion of its net income as is derived from sales made to the federal government.

58. Compare Panhandle Oil Co. v. Mississippi ex rel. Knox, 277 U.S. 218, 221 (1928) (rely ing upon Gillespie), with id. at 223 (Holmes, J., dissenting) ("[M] ost of the distinctions of the law are distinctions of degree.... The power to tax is not the power to destroy while this Court sits."). That state taxation impaired federal interests as a matter of degree had been sporadically recognized in previous Court opimions. See, e.g., Union Pac. R.R. Co. v. Peniston, 85 U.S. (18 Wall.) 5, 30-31 (1873):

But it is often a difficult question whether a tax imposed by a State does in faet invade the domain of the General government, or interfere with its operations to such an extent, or in such a manner, as to render it unwarranted. It cannot be that a State tax which remotely affects the efficient exercise of a Federal power is for that reason alone inhibited by the Constitution. To hold that would be to deny to the States all power to tax persons or property. Every tax levied by a State withdraws from the reach of Federal taxation a portion of the property from which it is taken, and to that extent diminishes the subject upon which Federal taxes may be laid. The States are, and they inust ever be, coexistent with the National government. Neither inay destroy the other. Hence the Federal Constitution must receive a practical construction. Its limitations and its implied prohibitions inust not be extended so far as to destroy the necessary powers of the States, or prevent their efficient exercise.

By the 1920 s, it could be said that

the Supreme Court has allowed states to tax the property of railroads cither created by the federal government, or employed by it; the property of telegraph companies erected under Act of Congress on military or postroads; the property of bridge compamies erected under Act of Congress across navigable rivers; and the premiums of a 
would embark on an increasingly frantic struggle to immunize state and federal instrumentalities from the effects of the other's taxation." Although this struggle was sometimes characterized as evidencing a commitment to "the logical and hiteral application of precedents," as distinct froin "practical judicial statesmanship," evidencing a formalist rather than a realist sensibility, in fact the Court's decisions expressed an escalating sensitivity to "the practical effect" of taxation. "The Taft Court was determined to delve beneath the surface of taxation scliemes to ascertain whether they actually impinged upon the distinct spheres of federal or state instrumentalities. Its intolerance of such impingements escalated as the decade progressed. In the end, however, the Taft Court's decisions would prove disastrous, because the goal of antiseptic separation toward which they aspired was wholly chimerical.

The difficulties of the Court's project are well illustrated by the notorious case of Panhandle Oil Co. v. Mississippi ex rel. Knox, ${ }^{62}$ in which the Court ruled that Mississippi could not apply a general tax on gasoline sales to the sales made by a local dealer to the United

bonding company authorized by statute to become surety on bonds required by the United States.

Note, Exemption of Federal Instrumentalities from State Taxation, 77 U. PA. L. REV. 115, 118 (1928). It could thus be concluded that the

cases seem to indicate that the Supreme Court is influenced by the closeness of the connection between the government and the alleged instrumentality claiming cxemption from taxation; and by the effect of the tax on that connection.... In some of the cases the connection is close and the effect on the government is direct, and the Court rules against taxation as a matter of law. In other cases the connection is less clear and the Court considers whether as a matter of fact the tax is an unreasonable interference with the government.

Id. at 119.

59. In the words of one commentator, the Court "materially" enlarged "the application of the doctrine, if not beyond its proper scope, certainly beyond the limits previously recognized." Note, Taxation: State Taxation of Federal Agencies and Instrumentalities, 13 MARQ. L. REV. 117, 121 (1929).

60. Note, supra note 57 , at 709.

61. Panhandle, 277 U.S. at 222 ("The validity of taxes claimed [on gasoline sales] is to be determined by the practical effect of enforcement in respect of sales to the government."); see Macallen Co. v. Massachusetts, 279 U.S. 620, 625 (1929) ("[N] either state courts nor legislatures, by giving the tax a particular name, or by using some form of words, can take away our duty to consider its nature and effect."); Nat'l Life Ins. Co. v. Umited States, 277 U.S. 508, 519 (1928) (holding that immunity cannot be evaded by any "device or form of words"); Northwestern Mut. Life Ins. Co. v. Wisconsin, 275 U.S. 136, 140 (1927) ("[1]f the challenged Act, whatever called, really imposes a direct charge upon interest derived from United States bonds, it is pro tanto void.").

62. 277 U.S. 218 (1928). Butler authored the decision. Dissenting were Stone, Holmes, McReynolds, and Brandeis. 
States "for the use of its Coast Guard Fleet in service in the Gulf of Mexico and its Veterans' Hospital at Gulfport. ${ }^{363}$ The Court held that "the validity of the taxes ... is to be determined by the practical effect of enforcement." ${ }^{, 64}$ Because the amount of the tax depended upon the quantity of gasoline sold to the United States, the Court reasoned that Mississippi had taxed the "transactions by which the United States secures the things desired for its governmental purposes." effect of the tax was "directly to retard, impede and burden the exertion of the United States of its constitutional powers to operate the fleet and hospital." 66

The notion that the doctrine of intergovernmental tax immunity precluded any state tax that increased the cost of ordinary purchases by instrumentalities of the federal government was breathtaking in its scope and implications. It aspired categorically to divide the domain of federal institutions front that of state taxation..$^{67}$ Any such ambition, however, was radically misguided, as Holines pointed out in a justly fainous dissent:

I am not aware that the President, the Members of Congress, the Judiciary or, to come nearer to the case in hand, the Coast Guard or the officials of the Veterans' Hospital, because they are instrumentahities of government and cannot function naked and unfed, hitherto having been held entitled to have their bills for food and clothing cut down so far as their butchers and tailors have been taxed on their sales; and I had not supposed that the butchers and tailors could omit from their tax returns all receipts froin the large class of custoiners to which I have referred. The question of interference with Government, I repeat, is one of reasonableness and degree and it seens to me that the interference in this case is too remote. ${ }^{68}$

63. Id. at 220.

64. Id. at 222 .

65. Id. at 221.

66. Id at 222 .

67. McReynolds (joined by Stone) dissented separately. "I am unable to think that every man who sells a gallon of gasoline to be used by the United States thereby becomes a federal instrumentality, with the privilege of claiming freedom from taxation by the state." $I d$. at 225 (McReynolds, J., dissenting).

68. Id. at 225 (Holınes, J. dissenting). Brandeis and Stone joined Holınes's opinion. Brandeis wrote Holnes that "This is fine \& I lumbly join." Louis D. Brandeis, Annotation to Circulated Draft Opinion in Panhandle Oil Co. v. Mississippi ex rel. Knox, Oliver Wendell Holmes Papers, Harvard Law School, Cambridge, Massachusetts [hereinafter Holmes Papers]. Stone wrote to his former law clerk Milton Handler that the case seemed "plain enough to me, but evidently not to others." Letter from Harlan Fiske Stone to Milton Handler (May 28, I928), Harlan Fiske Stone Papers, Library of Congress, Washington, D.C. [hereinafter Stone Papers]. 
The dissent is best known, however, for its repudiation of a position that Holmes lad earlier embraced, which is that the power to tax included the potential "to destroy." "In 1928, taking aim at Chief Justice Marshall's "often quoted proposition that the power to tax is the power to destroy," Holmes noted that

[i]n those days it was not recognized as it is today that most of the distinctions of the law are distinctions of degree. If the states had any power it was assumed that they had all power, and that the necessary alternative was to deny it altogether.... But this court which so often has defeated the attempt to tax in certain ways can defeat an attempt to discriminate or otherwise go too far without wholly abolishing the power to tax. The power to tax is not the power to destroy while this court sits. ${ }^{x}$

Because the Court could supervise the nature and extent of the burdens created by intergovernmental taxation, there was no need wholly to insulate either state or federal instrumentalities from the effects of the other's taxation. Hostile or destructive taxation could be blocked by the Court, whereas general, trivial, and nondiscriminatory taxes, like those at issue in Panhandle, could pass constitutional scrutiny.

The Taft Court, lowever, was unconvinced by Holmes's dissent. In fact the Court redoubled its efforts to disentangle the dual spheres of American sovereignty. Not only did it continue to regard the power to tax as potentially oppressive, but it also announced, in langnage that anticipates Alden v. Maine," that "for one government-

69. See supra note 56 and accompanying text.

70. Panhandle, 277 U.S. at 223 (Holmes, J., dissenting). Frankfurter immediately recognized a classic in the offing, writing Holmes that

the power to tax is not the power to destroy "while this Court sits," ought forever to reserve for the unuseum of judicial dicta Marshall's utterance. What hold words have on men-I sometimes suspect, particularly on our profession. These are really exciting opinions of yours-like sparkling wine in a dry age.

HOLMES AND FRANKFURTER: THEIR CORRESPONDENCE, 1912-1934, at 227 (Robert M. Mennel \& Christine L. Compston eds., 1996). Holmes wrote back to acknowledge the power of "phrases-they put water under the boat and float it over dangerous obstacles" Id. at 228. As early as 1923, Frankfurter had discussed with Brandeis "Marshall's dictum "power to tax, is power to destroy.' Said 'that was dreadful. Holmes always snorts at that. Marshall's dicta raised hell in all sorts of ways-taken terribly seriously."' Melvin I. Urofsky, The Brandeis-Frankfurter Conversations, 1985 SUP. Cr. REV. 299, 326.

71. 527 U.S. 706 (1999); Ann Althouse, On Dignity and Deference: The Supreme Court's New Federalism, 68 U. CIN. L. REv. 245 (2000); see also Evan H. Caminker, Judicial Solicitude for State Dignity, ANNALS AM. ACAD. POL. \& SOC. SCI., Mar. 2001, at 81, 83 (noting that the Supreme Court "gave dignitary interests center stage" in examining the role of state sovereign immunity in Alden v. Maine). 
state or national-to lay a tax upon the instrumentalities or securities of the other is derogatory to the latter's dignity, subversive of its powers, and repugnant to its paramount authority." "These constitute special and compelling reasons," the Court explained, "why courts, in scrutinizing taxing acts ... should be acute to distinguish between an exaction which in substance and reality is what it pretends to be, and a scheme to lay a tax upon a nontaxable subject by a deceptive use of words."73

Reflecting the urgency of this imperative, the Court in Macallen Co. v. Massachusetts ${ }^{74}$ reached out to eviscerate the important precedent of Flint $v$. Stone Tracy Co. ${ }^{75}$ which had held that a state could impose "excise" taxes on a corporate franchise, measuring the value of the franchise "by incoine from the property of the corporation although a part of such incoine is derived from nontaxable property." In effect, Macallen prohibited states from assessing taxes on corporations based upon the value of or income arising from corporate holdings in federal securities. The constitutionahity of such taxes, Macallen reasoned, could not be determined inerely by the label "excise tax," for when a state includes im the measure of a tax the value of nontaxable property, the "probabihty" exists that "the real purpose" of the tax is "to reach" the protected property. ${ }^{n}$ Pursuing a thoroughly skeptical and realistic agenda, the Court stressed that it was "essential to

72. Macallen Co. v. Massachusetts, 279 U.S. 620, 628 (1929).

73. Id. at 629.

74. 279 U.S. 620 (1929).

75. 220 U.S. 107 (1911).

76. Macallen, 279 U.S. at 628. In dissent, Stone, writing also for Holmes and Brandeis, queried the urgency of the Court's judgment:

For seventy years this Court has consistently adhered to the principle that either the federal or state governments may constitutionally impose an excise tax on corporations for the privilege of doing business in corporate form, and measure the tax by the property or net incoine of the corporation, including the tax-exempt securitics of the other or income derived froin them....

It would seein that only considerations of public policy of weight, which appear to be here wholly wanting, would justify overturning a primciple so long established. It has survived a great war, financed by the sale of government obligations, and it has never even been suggested that in any practical way it has impaired either the dignity or credit of the national government.

Id. at 636, 637 (Stone, J., dissentimg). Stone wrote to Professor Noel Dowling that a recent decision "in effect overruling Flint v. Stone-Tracy Co." was one of "the notable cases of the year." Letter from Harlan Fiske Stone to Noel T. Dowling (June 4, 1929), Stone Papers, supra note 68. To Milton Handler, Stone wrote that he found Macallen a "startling innovation." Letter from Harlan Fiske Stone to Milton Handler (May 29, 1929), Stone Papers, stupra note 68.

77. Macallen, 279 U.S. at 629. 
the preservation of the constitutional limitations imposed upon the taxing power of the states" that courts "look beyond the words to the real legislative purpose." If these limitations could "be evaded by the adoption of a delnsive name to characterize the tax or form of words to describe it, the destruction of the vitahty of these necessary safeguards will soon follow."

The Court's concern to police the boundary between national and state governments reached its apogee in the case of Long $v$. Rockwood, ${ }^{80}$ which, despite a devastating Holmes dissent, held that royalties from federal patents could not be taxed by states. ${ }^{81}$ Long seemed to imply that incoine froin any federally created right was immune from state taxation. This imphication was so extreme that Long was unanimously overruled ouly four years later in a case involving state taxation of royalties froin federal copyrights."

The overreaclimg of Long, the urgency of Macallen, and the obsessive scrupulousness of Panhandle, all evidence the Taft Court's increasingly anxious efforts to maintam the spheres of federal and state power as distinct and inutually exclusive. Stone put his finger on the root problem when he observed that, following Marshall, the Court "dealt with the whole question as an infrimgement of sovereignty and treated the sovereignty infringed as though it were that of a government wholly foreigu to the taxing government, and thus, I think, left out of account the necessity of making the two governments function together as part of one system." ${ }^{\text {" It }}$ was clear to Stone that the whole framework of analysis had to be fundamentally reconceived.

Stone attempted the task in 1926 in his opinion for a unanimous Court in Metcalf $v$. Mitchell, ${ }^{84}$ which concerned the question of

78. Id. at 630-31. This reasoning is discussed in Thomas Reed Powell, An Imaginary Judicial Opinion, 44 HARV. L. REV. 889, $901-904$ (1931).

79. Macallen, 279 U.S. at 631.

80. 277 U.S. 142 (1928).

81. Holmes was joined by Brandeis, Sutherland, and Stone. After the argunent of the case, Holmes wrote Frederick Pollock that "I shall try to smash" the notion "that patents can't be taxed." 2 HOLMES-POLLOCK LETTERS: THE CORRESPONDENCE OF MR. JUSTICE HOLIES AND SIR FREDERICK POLIOCK, 1874-1932, at 215 (Mark DeWolfe Howe ed., 1946) (hereinafter HOLMES-POLLOCK LETTERS].

82. Fox Film Corp. v. Doyal, 286 U.S. 123, 131 (1932).

83. Letter from Harlan Fiske Stone to Thomas Reed Powell (Jan. 30, 1931), Stone Papers, supra note 68. Corwin would later coin the term "Cooperative Federalism" to describe the vision implicit in Stone's observation. Corwin, supra note 45, at 19-21.

84. 269 U.S. 514 (1926). According to Stone's docket book, only Sutherland had roted the other way in conference. He wrote to Stone that "I felt rather strongly the other way, but I shall yield. You have written a good opinion and if we are to draw what seems to me to be a rather 
whether federal income tax could be applied to fees received by consulting engineers "professionally employed to advise states or subdivisions of states with reference to proposed water supply and sewage disposal systems." ${ }^{\text {"S5 }}$ Stone, who had been on the Court for less than a year, aspired to rethink the doctrine of intergovernmental tax immuinty from the ground up. ${ }^{86}$ Noting, on the one hand, that "those agencies through which either government immediately and directly exercises its sovereign powers, are immune froin the taxing power of the other," and, on the other hand, that "not every person who uses his property or derives a profit, in his dealings with the government, may clothe himself with immunity from taxation on the theory that either he or his property is an instrumentahty of government," ceived that "the line which separates those activities having some relation to government, which are nevertheless subject to taxation, from those which are immune" can be ascertained only by reference "to the reason upon which the rule rests, and which must be the guiding principle to control its operation. ${ }^{989}$

Stone was therefore required to articulate the fundamental "reason" for the doctrine. Denying the premise of dual sovereignty, he concluded that the doctrine's basic purpose could not be to make federal and state governments immune from the effects of the taxation of the other, because "the taxing power of either government, even when exercised in a unanner admittedly necessary and proper, unavoidably has soine effect upon the other.... Taxation by either the state or the federal governinent affects in some measure the cost of operation of the other." Instead, Stone sought to capture the essential point of the doctrine in the notion that

neither government may destroy the other nor curtail in any substantial manner the exercise of its powers. Hence the limitation

arbitrary line, perhaps this is good as any." George Sutherland, Annotation to Circulated Draft Opinion in Metcalf v. Mitchell, Stone Papers, supra note 68. Brandeis wrote to Stone, "As already stated I shall abide the view of the Conference on your statement of the point discussed by us." Louis D. Brandeis, id. Van Devanter wrote, "I quite agree," adding some excellent cditing suggestions. Willis Van Devanter, $i d$.

85. Metcalf, 269 U.S. at 518.

86. Stone later wrote to Professor Noel Dowling at Columbia that "[t]he cases are in a very great state of confusion and I doubt whether there is any way of reducing them into a semblance of order except along the lines indicated in [Metcalf]." Letter from Harlan Fiske Stone to Noel T. Dowling (Jan. 22, 1926), Stone Papers, supra note 68.

87. Metcalf, 269 U.S. at 522.

88. Id. at 522-23.

89. Id. at 523 .

90. Id. 
upon the taxing power of each, so far as it affects the other, must receive a practical construction which permits both to function with the minimum of interference each with the other; and that limitation cannot be so varied or extended as seriously to impair either the taxing power of the government imposing the tax... or the appropriate exercise of the functions of the government affected by it."

Stone's reconceptualization of the doctrine of intergovernmental tax immunity would not take root until the $1930 \mathrm{~s}^{\text {.2 }}$ For the remainder of its brief span, the Taft Court would not use the doctrine to analyze the effects of taxation on both the government taxing and the government taxed, nor would it direct attention to the degree of interference with governmental function. Instead it would remain fixated on the goal of absolutely immunizing both federal and state governments from the effects of the other's taxation. ${ }^{93}$ In dissent in Macallen, Stone pleaded for the Court to adopt the new perspective advanced in Metcalf, ${ }^{44}$ but to no avail.

\section{FEDERALISM AND THE SCOPE OF CONGRESSIONAL POWER}

The Taft Court's determination to use the doctrine of intergovernmental tax immunity to enforce a strict separation between distinct spheres of national and state anthority displays a starthing, if not unnerving, intensity. We should interpret this intensity as a response not merely to the transformations occasioned by World War I, but also to the Court's own comphicity in these transformations. World War I had demonstrated how effectively the federal government could address issues of national scope, whether or not these issues had traditionally been allocated to a distinct sphere of state sovereignty. Taft Court decisions recognized this fact by expanding the constitutional range of congressional power. By sanctioning hitherto

91. Id. at 523-24 (citations omitted).

92. For a discussion of the sea change that overtook the doctrine in that decade and subsequently, see Powell, supra note 78, at 891-905.

93. In 1930, Frankfurter wrote Stone observing that

your Court has certainly been tearing up what one had supposed were rather deeprooted foundations in the law of taxation.... [O]ur federalism is dependent on leaving sources of taxation open to both states and nation without too many artificial restrictions, and particularly restrictions as rigid and iron as constitutional adjudications involve.... I believe that the expression of your individual views upon these matters is profoundly important in the ultimate development of the Court's ideas.

Letter froin Felix Frankfurter to Harlan Fiske Stone (May 22, 1930), Stone Papers, supra note 68.

94. Macallen Co. v. Massachusetts, 279 U.S. 620, 637 (1929) (Stone, J., dissenting). 
unexercised forms of national legislative authority, the Taft Court itself participated in blurring the separate spheres of state and federal sovereignty.

In the context of congressional power, as in the context of intergovernmental tax immunity, the Taft Court had inherited the conceptual framework of dual sovereignty. The classic statement may be found in United States v. E.C. Knight Co., ${ }^{95}$ which struck down the application of the Sherman Antitrust Act to the manufacturing of sugar:

It cannot be denied that the power of a State to protect the lives, health, and property of its citizens, and to preserve good order and the public morals, "the power to govern men and things within the limits of its dominion," is a power originally and always belonging to the States, not surrendered by them to the general government, nor directly restramed by the Constitution of the United States, and essentially exclusive.... On the other hand, the power of Congress to regulate commerce among the several States is also exclusive....

It is vital that the independence of the commercial power and of the police power, and the delimitation between thein, however sometimes perplexing, should always be recognized and observed, for while the one furnishes the strongest bond of union, the other is essential to the preservation of the autonomy of the States as required by our dual form of government; and acknowledged evils, however grave and urgent they may appear to be, had better be borne, than the risk be run, in the effort to suppress them, of more serious consequences by resort to expedients of even doubtful constitutionality....

... Slight reflection will show that if the national power extends to all contracts and combinations im manufacture, agriculture, mining, and other productive industries, whose ultimate result may affect external commerce, comparatively little of business operations and affairs would be left for state control. ${ }^{96}$

E.C. Knight intimated that federal power could reach transactions otherwise within the "exclusive" jurisdiction of state "police power" if the parties involved possessed the "intention to put a restraint upon trade or commerce." Subsequent decisions like Swift \&

95. 156 U.S. 1 (1895).

96. Id. at $11,13,16$.

97. Id. at 17,19 . 
Co. v. United States $^{98}$ explicitly confirmed that federal antitrust law could regulate such transactions if performed with an "intent ... to aid in an attempt to monopolize commerce among the states." The Taft Court scrupulously maintained this boundary between state and federal authority in its interpretation of federal antitrust law.

In United Mine Workers v. Coronado Coal Co., ${ }^{100}$ for example, the Court reversed a trial court judgment holding a umion hable for violations of the Sherman Act. The Taft Court concluded that because "[c]oal mining is not imterstate commerce, and the power of Congress does not extend to its regulation as such," ernment could not penalize a union even for striking against the production of coal destined for interstate commerce, "unless the obstruction to mining is intended to restrain commerce." ${ }^{103}$ The Court enforced this limitation on national authority despite an earnest desire to punish the union. Taft concluded his opinion for the Court by noting that "the circumstances are such as to awaken regret that, in our view of the Federal jurisdiction, we cannot affirm the judgment. But it is of far higher importance that we should preserve inviolate the fundamental limitations in respect to the Federal jurisdiction."

\footnotetext{
98. 196 U.S. 375 (1905).

99. Id. at 398.

100. 259 U.S. 344 (1922).

101. Id. at 407.

102. Id. at 408:
}

In Hammer v. Dagenhart, 247 U.S. 251, 272, we said: "The making of goods and the mining of coal are not commerce, nor does the fact that these things are to be afterwards shipped, or used in interstate commerce, make their production a part thereof. Delaware, Lackawanna \& Western R.R. Co. v. Yurkonis, 238 U.S. 439." Obstruction to coal mining is not a direct obstruction to interstate commcrce in coal, although it, of course, may affect it by reducing the amount of coal to be carried in that commerce. We have had occasion to consider the principles governing the validity of congressional restraint of such indirect obstructions to interstate commerce in Swift \& Co. v. United States, 196 U.S. $375 \ldots$

103. Id. at 411 . The Court accordingly vacated a judgment against the defendant union because there "was no evidence submitted to the jury upon which they could properly find" intent "to restrain or monopolize interstate commerce." Id. at 413. For an account of the genesis of Taft's opinion in the case, see ALEXANDER M. BICKEL, THE UNPUBLISHED OPINIONS OF MR. JUSTICE BRANDEIS: THE SUPREME COURT AT WORK 77-99 (1957).

104. Coronado Coal Co., 259 U.S. at 411. Upon recciving the draft of Taft's opinion, McReynolds wrote back, "I am sorry you can't make the scoundrels pay!" James C. McReynolds, Annotation to Circulated Draft Opinion in United Mine Workers v. Coronado Coal Co., William Howard Taft Papers, Library of Congress, Washington, D.C., Reel 615 [hereinafter Taft Papers]. Day answered, "I agree, and regret that this gross outrage by the local union cannot be reached by federal authority." William R Day, id. 
Although the influence of dual sovereignty on the Taft Court's interpretation of federal antitrust legislation is manifest, ${ }^{105}$ the Court in other contexts broke new ground in authorizing congressional leg. islation. A good example is the Court's staunch and continuous support for prohibition. ${ }^{106}$ After more than eighty years, it is difficult now fully to appreciate the extent to which contemporaries regarded the Eighteenth Amendment as "the most radical political and social experiment of our day," in no small measure because of its "attempt at . . rigid uniformity." National prohibition represented "[s]uch a blow at the prerogatives of the states, such a step toward centralization," as "would have been thought impossible by the men of 1787."109

105. The Taft Court consistently hewed to the Swift line of intent, which sometimes, as in Coronado Coal Co., had hiberal consequences, see, e.g., United Leather Workers' Int'l Union v. Herkert \& Meisel Trunk Co., 265 U.S. 457, 468-70 (1924) (holding that striking workers were not subject to federal regulation, despite their detrimental effect on interstate commerce), and sometimes did not, see, e.g., Indus. Ass'n of S.F. v. United States, 268 U.S. 64, 66 (1925) (finding that if there is no intent to restrain interstate commerce, participants in an industrial conflict inay refuse to sell building materials in a single city). In the Coronado case itself, evidence was eventually adduced justifying a conviction under federal antitrust law. Coronado Coal Co. v. United Mine Workers, 268 U.S. 295, 310 (1925).

106. See, e.g., Edward B. Dunford, Prohibition in Light of Stupreme Cottrt Decisions, N.Y. TIMES, June 1, 1930, § 3, at 4; John E. Monk, Watch-Towers, Drys Eye High Court; Count Possible Retirements in Fear Successors Might Incline to Wet Views, N.Y. TIMES, July 1, 1928, 83 , at 1 ("The Supreme Court, as at present constituted, uniformly has upheld the Eighteenth Amendment and the Volstead act in all the cases brought before it.").

107. Progressivism and Prohibition, NEW REPUBLIC, Apr. 21, 1926, at 262.

108. Editorial, The Supreme Court, N.Y. TIMES, Oct. 14, 1932, at 18; see also Nicholas Murray Butler, The Constitution One Hundred and Forty Years After, 12 CONST. REv. 122, 123 (1928) ("It is the complete departure from the fundamental primciples of the Constitution, and not at all the subject matter with which it deals, that makes the Eighteenth Amendment so objectionable and so offensive to everyone who imderstands American government ....").

109. PIERSON, supra note 40 , at 43 . Taft, for example, had vigorously opposed the adoption of federal prohibition, in part because he beheved that it was a disaster for proper prineiples of federalisin:

The people and Congress made a mistake, in my judgment, in accepting the war fervor for self-restraint on the part of the people as a basis for the Eighteenth Amend. ment, and the legislation passed to enforce it. I was opposed to the policy of the Amendment, because I thought prohibition could not be enforced effectively among our numerous population of foreign origin, especially when they were living in congested centers in large cities; second, because I thought it was dealing with a matter that was parochial and unduly extending the power of the Central Government, and unposing on it a burden that it sliould be free from; and third, because prohibition, as a political issue, was certain to divert popular attention away froon material issues upon which the undivided attention and good sense of the people should be centered to reacli a right conclusion. But unfortunately the coineidence of the War, the misconception of what was going on in Europe in respect to the prohibition of intoxicating liquor, and the teinporary spirit of self-restraint and sacrifice, put the measure through, and it is now working like a ratchet wheel, so that there is not the slightest cliance, for a great many years, of repeahing the Eighteenth Amendment, and we are put in a situation where we must fight it through and must enforce it, if we can. 
Yet the Taft Court, time and again, sometimes over strong dissent, upheld the prerogative of the federal government to regulate liquor.

Lambert v. Yellowley ${ }^{110}$ is exemplary. ${ }^{11}$ In Lambert, the Court considered a challenge by a prominent physician ${ }^{112}$ to provisions of the National Prohibition Act of $1919^{113}$ closely regulating low physicians could prescribe "spirituous liquor"114 to their patients. These provisions were said to be unconstitutional because "control [of] the medical practice in the States is beyond the power of the Federal Government."115 In a 5-4 opinion, the Court, per Justice

Letter from William Howard Taft to Francis Peabody (July 12, 1923), Taft Papers, supra note 104, Reel 255; see also U.S. BREWERS' ASS'N, THE 1918 YEAR BOOK OF THE UNITED STATES BREWERS' ASSOCLATION 21-27 (1919) (cataloguing letters and articles from 1918 which reveal Taft's vigorous opposition to the prohibition amendment); William Howard Taft, Is Prohibition a Blow at Personal Liberty?, LADIES HOME J., May 1919, at 31, 78 [heremafter Taft, Prohibition]; William Howard Taft, Wise and Unwise Extension of Federal Power, 1 Cossr. REv. 67, 76-78 (1917) [hereinafter Taft, Federal Power]:

[T] he wisdoun of mamtaining the safe structural plan of our government has no weight whatever with the advocates of national prohibition .... They must have the aid of that single executive, with that large organization directly subordinate, managed from Washington, which works without regard to local influence.... The political instrument that such a vast machine and army of office-holders will constitute in the hands of a sinister manipulator of national politics, it is most discouraging to contemplate.

William Howard Taft, Foreword to LORD SHAW, THE LAW OF THE KINSMEN 11-12 (1923): With many others, I was opposed strongly to national prohibition for the reasons, first, because I had grave doubt whether it could be enforced and feared the resulting demoralization of all law, second, because I deprecated much the undue expansion of the Federal jurisdiction and disturbance of the wise balance between national and state powers in our system, and, third, because I feared that no matter how drastic the law, the question would force itself as a constant issue in politics, diverting the public mind from important issues, and in the confusion preventing a well-considered clective decision of them.

By 1923, however, Taft had concluded that there is now "nothing to be done ... except to set ourselves to the serious task of enforcing the law and to cease protesting against its enactunent and by such an attitude encouraging its violation." Id. at 12.

110. 272 U.S. 581 (1926).

111. It was said, however, that the case "excited unusual interest and comment." Note, Constitutional Law-Power of Congress to Limit the Prescription of Intoxicating Liquors, 13 VA. L. REV. 311, 312 (1927).

112. The doctor was Samuel W. Lambert, "a distinguislued New York physician." Robert Cushinan, Constitutional Law in 1926-1927, 22 AM. POL. SCI. REV. 70, 82 (1928). Dr. Lambert was the "president of the Association for the Protection of Constitutional Rights, which was organized ... by 105 physicians" to challenge federal control of the authority of doctors to prescribe liquor. Unlimited Liquor Prescription, LITERARY DIG., May 26, 1923, at 10. For a biography of Lambert, see 37 THE NATIONAL CYCLOPEDIA OF AMERICAN BIOGRAPHY 281 (1951).

113. Pub. L. No. 66-66, \& 7,41 Stat. $305,311$.

114. Lambert, 272 U.S. at 587.

115. Id. at 596 . 
Brandeis, ${ }^{116}$ upheld congressional power in extraordinarily generous terms:

When the United States exerts any of the powers conferred upon it by the Constitution, no valid objection can be based upon the fact that such exercise may be attended by sonie or all of the incidents which attend the exercise by a State of its police power.... The Eighteenth Amendnient confers upon the Federal Government the power to prohibit the sale of intoxicating liquor for beverage purposes. Under it, as under the "necessary and proper" clause of Article I, $\S 8$ of the Constitution, Congress has power to enforce prohibition "by appropriate legislation." High medical authority being in conflict as to the medicinal value of spirituous and vinous liquors taken as a beverage, it would, indeed, be strange if Congress lacked the power to determine that the necessities of the liquor problem require a limitation of permissible prescriptions, as by keeping the quantity that may be prescribed within limits which will minimize the teniptation to resort to prescriptions as pretexts for obtaining hquor for beverage uses. ${ }^{11}$

116. The Brandeis papers indicate that Taft and Van Devanter extensively modified Brandeis's opinion. Lambert v. Yellowley file, Louis D. Brandeis Papers, Harvard Law School, Cambridge, Massachusetts [hereinafter Brandeis Papers]. Taft wrote Van Devanter that "I am pcrfectly delighted that you made your addition to B's opinion. It shows up the weakness of the dissent." Letter from William Howard Taft to Willis Van Devanter (Nov. 30, 1926), Willis Van Devanter Papers, Library of Congress, Washington, D.C. [hereinafter Van Devanter Papers].

117. Lambert, 272 U.S. at 596-97. Taft, Holmes, Van Devanter, and Sanford joined Brandeis's opinion. For similar decisions, see Selzman v. United States, 268 U.S. 466, 469 (1925) (upholding the Eighteenth Amendnient with respect to denatured alcohol), and James Everard's Breweries v. Day, 265 U.S. 545, 563 (1924) (upholding the prohibition on prescriptions of intoxicating liquors for medicinal purposes). Curiously, the plaintiff in Lambert, Dr. Samuel Lambert, was a close personal acquaintance of Taft and served as a physician to Taft's relatives in the New York area. See Letter froin William Howard Taft to Mrs. Willianı A. Edwards (Nov. 17, 1922), Taft Papers, supra note 104, Reel 247 ("I am glad to think that Horace is better. The trace of albumen hasn't disappeared, but his diet has evidently done him good, and Sam Lambert has now [illegible] him to eat some eggs but no meat."); Letter from William Howard Taft to Horace D. Taft (Nov. 9, 1922), id. ("I am very glad that Sam thinks you have gained in the last eight months. It seenied to ine, when I saw you in New York, that you looked much better."); Letter fronı Horace D. Taft to Willianı Howard Taft (Nov. 2, 1922), id.; Letter from William Howard Taft to Horace D. Taft (Oct. 26, 1922), id., Reel 246. In fact, after the decision in Lambert, Taft wrote his brother that

Sam Lambert's wife was here as one of Nellie's Colonial Dames and when I saw her I told her that if she had nianaged the case, with her direct methods, because she appealed to ine, as I told you, by seizing my coat lapel and saying that I must decide for Sain, the case might have gone what she thought was the right way. I told her to tell Joe Auerback that if she had been employed as counsel, the result might have been different.

Letter from William Howard Taft to Horace D. Taft (May 24, 1927), id., Reel 292. After the Court's decision, Lambert filed a petition for rehearing, argning that the Court had in its opinion mistakenly believed that the majority of physicians were "opposed to the use of alcohol as a 
The Court reached its decision in the teeth of a strong dissent by Sutherland (joined by McReynolds, Butler, and Stone), which stressed the tension between the Court's interpretation of national authority and the traditional ideology of separate spheres:

The general design of the federal Constitution is to give to the federal government control over national and international matters, leaving to the several states the control of local affairs. Prior to the adoption of the Eighteenth Amendment, accordingly, the direct control of the manufacture, sale and use of intoxicatimg hiquors for all purposes was exclusively under the police powers of the states; and there it still remains, save insofar as it has been taken away by the words of the Amendment. These words are perfectly plain and cannot be extended beyond their import without violating the fundamental rule that the government of the United States is one of delegated powers only and that "the powers not delegated to the United States by the Constitution, nor prohibited by it to the States, are reserved to the States respectively, or to the people." The pertinent words of the Amendment are: "... the manufacture, sale, or transportation of intoxicating liquors... for beverage purposes is hereby prohibited." Plainly, Congress in submitting the Amendment, and the several states in ratifying it, meant to leave the question of the

therapeutic." Liquor As Medicine Ruling Under Fire, N.Y. TMIES, Dec. 14, 1926, at 17. Taft wrote his brother Horace:

I don't see just how Sam Lambert can try again on the question, for we intended to make an end of him, and I think we have done so. If he thinks we are going back to try over the question whether a majority of doctors are in favor or opposed to larger hberality in the matter of the use of whiskey as a medicinal agent, he is greatly mistaken. I used to think that the prohibitionists were the craziest people in the landscape, but I really think their opponents are more nearly lunaties than they.

Letter from William Howard Taft to Horace D. Taft (Jan. 16, 1927). Taft Papers, supra note 104, Reel 288. After the Court's derial of Lambert's petition, Horace replied, "I see that you have turned down Sam Lambert and I hope that now he can get some sleep." Letter from Horace D. Taft to William Howard Taft (Jan. 18, 1927), id. Lambert, however, continued to press his case, arguing for the medicinal value of hiquor "in the treatment of many diseases and nervous conditions, particularly those of the aged." Advocates Liquor as Benefit to Aged; Lambert of Medical Academy Urges Doctors to Force New Dry Law from Congress, N.Y. TIMES, Oct. 5, 1928, at 27; see also Letter from Horace D. Taft to William Howard Taft (Oct. 19, 1928), Taft Papers, supra note 104, Reel 305:

Another piece of delicious absurdity comes from a quotation by the Wets of San Lambert. Nothing is so firmly fixed in the minds of the Wets or so loudly trumpeted as that we are drinking inore than ever under prohibition. Now comes $S a n$ in an address and states that there has been a dreadful increase in diabetes, because alcohol is needed to burn up the sugar in the human system and now that people have so largely given up alcoholic drinks the increase in diabetes oocurs. The Wets rejoice over this decision by a high medical authority and are quite capable of citing in parallel columns the two arguments against prohibition, one that we are drinking inore than ever and the other that the fact that we are drinking so hittle is destroying us. 
prohibition of intoxicating liquors for other than beverage purposes to the determination of the states, where it had always been. The limiting words of the Amendment are not susceptible of any other meaming; and to extend them beyond the scope of that meaning really is to substitute words of another and different import....

... It is true that Congress has wide discretion in the choice of means to carry the granted power into effect; but the means not only must be appropriate to the end but must be such as "are not prohibited, but consist with the letter and spirit of the Constitution." McCulloch v. Maryland, [17 U.S.] 4 Wheat. 316, 412 [(1819)]. A grant of power to prohibit for specified purposes does not include the power to prohibit for other and different purposes. Congressional legislation directly prohibiting intoxicating liquor for concededly medical purposes, therefore, does not consist with the letter and spirit of the Constitution, and viewed as a means of carrying into effect the granted power is in fraud of that instrument, and especially of the Tenth Amendment.... The effect of upholding the legislation is to deprive the states of the exclusive power, which the Eighteenth Amendment has not destroyed, of controlling medical practice and transfer it in part to Congress.

118. Lambert, 272 U.S. at 597-98, 603-04 (Sutherland, J., dissenting). For Sutherland's viows of the Eighteenth Amendment, see Letter from George Sutherland to William D. Guthrie (Mar, 15, 1920), George Sutherland Papers, Library of Congress, Washington, D.C. [hereinafter Sutherland Papers]. "The truth about it is," Sutherland observed, "I do not beliovo that anybody, in either House of Congress had the shightest idea what was intended by" the Amendmont. Id. Sutherland concluded, however, that the Amendment was best interpreted as accomplishing "three things."

1. - It absolutely prohibits the manufacture, sale, transportation, exportation and importation of intoxicating liquors for beverage purposes.... The framers of the Amendment, while desiring to make an unqualified prohibition, did not desire to interfere with the internal powers of the States to deal with the subject in its local as distinguished from its national aspect. Therefore, the provision which they framed for the enforcement of the Amendment is to be construed:

2. - As authorizing Congress to enforce it by appropriate legislation, - that is, in its federal aspect, and,

3. - As authorizing the several States to enforce it by appropriate legislation, - that is, in its various local aspects.

I quite understand that the foregoing suggestion is open to the objection that it does violence to the precise language of the Amendment, but it is the only theory which I have been able to evolve that will make the Amendment at all workable, and which will prevent the destruction of the historic relations of the Federal and State Governments ....

Id. In Sutherland's view, the Eighteenth Amendinent's reference to the "concurrent power" of enforcement was internally contradictory, so that the Court would have to "construct a meaning," and in so doing 
Another example of the Taft Court's deference to congressional authority is its treatment of conditional federal grants. Such grants are now an essential component of federal-state relations, but in the 1920 s they were relatively new and regarded with deep suspicion, as "an exceedingly potent and imsidious influence, leading state officials to surrender voluntarily state prerogatives in exchange for appropriations of federal money." 119 President Coohidge himself characterized conditional federal grants as an "insidious practice which sugar-coats the dose of Federal intrusion." "The ardent States' rights advocate," said Coolidge,

sees in this practice a vicious weakening of the State system. The extreme Federalist is apt to look upon it in cynical fashion as bribing the States into subordination. The average American, believing in our dual-sovereignty system, must feel that the policy of national doles to the States is bad and may become disastrous. ${ }^{121}$

The constitutionality of conditional federal grants came before the Taft Court in the form of a challenge to the Sheppard-Towner Act, ${ }^{122}$ which established an innovative federal program authorizing annual grants to states that met certain conditions for the improvement of maternal and infant liealth. ${ }^{123}$ The Act was characterized as "a usurpation of power not granted to Congress by the Constitution-an attempted exercise of the power of local self-government reserved to the states by the 10th Amendment." ${ }^{124}$ It was said to deploy federal

[t]he most powerful extrinsic aid ... is that afforded by the general plan and purpose of the constitution as a whole, which clearly is to commit to the general government control over the inter-relations of the states and their peoples, while leaving to the states control over individuals and individual interests, and over local and internal matters of police.

Letter from George Sutherland to William D. Guthrie (Mar. 18, 1920), Sutherland Papers, supra.

119. PIERSON, supra note 40 , at 22 ; see also Briggs, supra note 29 , at $308-09$ (tracing the widespread reaction against the increasing authority of the national government to the "national control of state activities through the system of 'federal aid"').

120. Coolidge, supra note 28 , at 2.

121. Id.

122. Pub. L. No. 97-67, 42 Stat. 224.

123. For a discussion of the Act, see THEDA SKOCPOL, PROTECTING SOldiERS AND MOthers: THE POLITICAL ORIGINS OF SOCIAL POLICY IN THE UNTrEd STATES 480-524 (1992).

124. Massachusetts v. Mellon, 262 U.S. 447, 479 (1923); see also State Rights and Baby Welfare, LITERARY DrG., Apr. 8, 1922, at 37 (discussing the dispute as to whether the SheppardTowner Act was an invasion of states' rights); Those 'Dangerous' Federal Doles, LrTERARY DiG., July 18, 1925, at 12; Fears Federal Grip: Maine Governor Sees National Government Encroaching on State's Activities, N.Y. TIMES, Dec. 21, 1921, at 16; Govemors Divide Over Federal 
spending power "for purposes not national, but local to the States," and to be unconstitutional because it was "an effective means of inducing the States to yield a portion of their sovereign rights." 123 In Massachusetts $v$. Mellon, however, the Court repulsed this attack on the Act. The Court crafted standing and political question doctrines that to this day have essentially precluded judicial oversight of the federalisin implications of the national spending power.

\section{A. Congressional Power and the Commerce Clause}

In botll Lambert and Mellon the Taft Court approved innovative forms of congressional power that blurred traditional boundaries between national and state sovereignty. It interpreted congressional authority as adequate to meet national needs, regardless of the intent of the persons regulated, and regardless of whether the underlying transactions could be characterized as within the customary sphere of federal authority. But both Lambert and Mellon involved relatively specific grants of congressional power that did not threaten a potentially limitless extension of national authority. The most striking aspect of the Taft Court's jurisprudence of congressional power, therefore, concerned its generous recognition of national regulatory power under the Commerce Clause, which was a dangerously expansive basis of federal authority. The Court's reading of the congressional commerce power was propelled by its acute perception of the growing integration of the national market.

A telling example is the Taft Court's treatment of the Transportation Act of $1920 .^{126}$ After seizing control of the nation's railroads during the war, the federal government was forced to confront the question of whetlier and how to return them to private ownership after the Armistice. The problem was that even before the war the railroads were in dire financial straits; "[a] decade of [Interstate Commerce Commission] resistance to rate increases, along with the roads'

Aid, N.Y. TIMES, July 1,1925, at 1 . The Sheppard-Towner Act was routinely included on the list of federal usurpations of state power. E.g., William Cabell Bruce, Recent Strides of Federal Authority, 77 SCRIBNER's MAG. 639, 643 (1925) (arguing "that a more insidious method of tempting the states to submit to Federal encroachment ... could not well be concocted"); Ritcr, supra note 29, at 645; Warren, supra note 35, at 375; Editorial, Back to the Constitution, N.Y. TIMES, Jan. 23, 1922, at 10.

125. Mellon, 262 U.S. at 479.

126. Pub. L. No. 66-152, 41 Stat. 456. 
mismanagement and earlier overcapitalization, impeded the modernization of trackage and rolling stock."27 It would not do simply to remand the railroads to this unsatisfactory condition. The solution was the Transportation Act of 1920, which constituted "an important change im railroad regulation, from the restrained, reactive prewar style to a more interventionist pohicy."

The Act was designed not merely to protect the public, but also "to extend positive aid to the carriers that their roads might be more efficient aids to interstate commerce." 129 In essence, the Act "rewrote railroad regulatory policy and for the first time created a single, national railroad system."130 The Act authorized "sweeping," "pervasive," and "detailed" forms of "federal control,"131 whose ambitious purpose was to "maintain an adequate railway service for the people of the United States."132 The Act was premised squarely on the view that railroad transportation, which provided the structural underpinnings of the national market, was a nationwide issue that required compreliensive and proactive federal attention.

Almost as soon as he became Chief Justice, Taft inherited a "very important case" ${ }^{\text {"133 }}$ from Wisconsin that challenged the authority of the Interstate Commerce Commission (ICC) to preempt intrastate railroad rates inerely on the ground that the ICC beheved these rates too low to ensure the financial liealth of the nation's interstate railroad system. ${ }^{134}$ At issue was the capacity of state railroad commissions

127. MORTON Keller, Regulating a NeW ECONOMY: PUblic POLICY AND ECONOMIC CHANGE IN AMERICA, 1900-1933, at 50 (1990).

128. Id. at 53. It was recognized at the time that the Act was "fundamentally different from anything that had ever before existed." Daniel Willard, Transportation Act as Solution of Rnilroad Problem, 69 RAILWAY AgE 787, 787 (1920).

129. James M. Beck, Federal Power over Intrastate Railroad Rates, 71 U. PA. L. REV. 11, 12 (1922).

130. HERBERT HOVENKAMP, ENTERPRISE AND AMERICAN LAW 1836-1937, at 166 (1991).

131. The 'Return' of the Railroads, NEW REPUBLIC, Mar. 3,1920, at 6.

132. Note, Federal Control of Intrastate Railroad Rates, 35 HARV. L REV. 864,865 (1922).

133. Letter from William Howard Taft to Horace D. Taft (Dec. 24, 1921), Taft Papers, supra note 104, Reel 237.

134. R.R. Comm'n v. Chi., Burlington \& Quincy R.R. Co., 257 U.S. 563 (1922). The case differed from the earlier Shreveport Case because Slireveport had concerned ICC power to remedy discrete discrimination caused by particular intrastate rates. Houston, E. \& W. Tex. Ry. Co. v. United States, 234 U.S. 342 (1914). The Wisconsin rate case, in contrast, involved a blanket ICC order raising all intrastate rates, whether or not they "work[ed] a diserimination against interstate travelers," 257 U.S. at 580 , on the ground that a gencral increase in rates was necessary "to make the system adequate to the needs of the country by securing for it a reasonably compensatory return for all the work it does," id. at 589. See also id. at 585-86:

Intrastate rates and the income from them must play a most important part in maimtaining an adequate national railway system.... The effective operation of the 
to maintain control over local rates, a matter of huge significance. The power of the ICC under the Act was accordingly "assailed, not only by Wisconsin but also twenty other states, whose attorneys general filed briefs as amici curice."

Taft promptly authored a unanimous ${ }^{136}$ and starkly nationalist ${ }^{137}$ opinion, which rested on the premise that "[c]onumerce is a unit and

[Transportation] act will reasonably and justly require that intrastate traffic should pay a fair proportionate share of the cost of maintaining an adequate railway system.

"This at first glance seems to go beyond the doctrine of the Shreveport Case in that in effect it requires local commerce to help interstate commerce and not merely to refrain from hindering it." Thomas Reed Powell, The Supreme Court's Review of Legislation in 1921-1922, 37 POL. SCI. Q. 486, 489 (1922).

135. Edward S. Corwin, Constitutional Law in 1921-1922, 16 AM. POL. SCI. Rev. 612, 619 (1922).

136. We have in the Van Devanter papers an undated, handwritten note from Taft asking Van Devanter to review his opinion "before I circulate it. I would like your judgment on it and especially on the last part of it where I briefly discuss the validity of the act. Am I too abrupt or sweeping in my hypothetical generalizations...? ?" Note from William Howard Taft to Willis Van Devanter (n.d.), Van Devanter Papers, supra note 116. At the time there was apparently in circulation a memorandum by Brandeis proposing that the case be decided on narrower and more technical grounds, which did not explicitly embrace the goal of ellsuring the financial health of the railroads. See Memorandum by Mr. Justice Brandeis (Sept. 24, 1921), Taft Papers, supra note 104, Reel 617. Van Devanter wrote back to Taft disapproving Brandeis's memorandum because it entailed "too much straining to keep a large conveyance in a narrow path." Letter from Willis Van Devanter to William Howard Taft (n.d.), id., Reel 249. "There is also an entire failure to recognize ... other new provisions which are designed to secure a fair revenuc to the carriers so that they may appropriately discharge their functions and be of real service to commerce and the public." $1 d$. By contrast, Van Devanter "thoroughly" agreed with Taft's "strong opinion," suggesting only that it could be "strengthened by a short statement at an appropriate place of how closely interstate and intrastate commerce are intertwined." $1 d$.

There also exists an undated letter from McReynolds to Taft stating that MoRcynolds did not "want to fail in iny obligation of frankness with you," and informing Taft that "I do not like yr. [sic] opinion." Letter from James C. McReynolds to William Howard Taft (n.d.), Taft Papers, supra note 104, Reel 249. McReynolds thought the opinion hard "to follow and . . . almost sure to produce confusion and add to our difficulties. The subject is of tremendous importance and should be put in the clearest possible way with no non-essential matter." 1ll. Taft's opinion issued on February 27, 1922. As of February 11, 1922, however, Taft was still worrying to Van Devanter that there was still "no word froin Brandeis or McReynolds.... They are forging thunderbolts, I suppose." Letter from Williain Howard Taft to Willis Van Devanter (Feb. 11, 1922), Van Devanter Papers, supra note 116. Eventually Taft acquired a unatrimous court on the ground, as he later wrote to his brother, that the ICC has power

to require state authorities to keep up their intrastate rates so as to contribute a fair share to the cost of running the railroad system. The agricultural bloc will not like the decision and there will probably be soine effort to amend the law, and I think it may be successful, but the law is a good one, and I hope any attempt to amend it may be defeated. We had a unanimous judgment in that case, which gives it a good deal of weight. I worked hard on the case and wrote and rewrote the opinion, and finally got it into fair shape.

Letter from William Howard Taft to Horace D. Taft (Feb. 28, 1922), Taft Papers, supra notc 104, Reel 239. Almost a year later, Brandeis complained to Frankfurter that more ICC cases ought to be assigned to him, 
does not regard state lines. ${ }^{\text {"138 }}$ The Court held that Congress had authority to enact the "new departure" of the Transportation Act of 1920 , because plenary federal control was necessary "to mamtain an adequate railway service for the people of the United States." immediately recognized that the "practical effect" of the Wisconsin rate case was virtually to sweep "state regulatory powers out of existeuce," at least "to the extent necessary to protect interstate carriers in the enjoyment of such revenues as the federal commission finds necessary to then in the public interest."1100 In a private letter to Taft, Van Devanter argued that national authority should be justified as necessary to safeguard the structural nitegration of the national market. "It would tend to commend the new enactment and the decision to the public mind," he wrote,

if, instead of indicating that the chief purpose of the new enactment is to put the carriers on their feet and to benefit them, it were also indicated that this is a means to an end and that the real end is to bring about efficient transportation highways and instrumentalities whereby the present and the increasing needs of the public will be met and satisfied, whereby the means will be at hand for readily

like [the] Wisconsin Rate Cases ... but first White and then Taft took it. Both asked me to talk with them about the cases. White's opinion was so bad I had it go overthen Taft took it, \& though he knew practically nothing about it he felt he ought to write it. He was very mice in the suggestions he took from me.

Urofsky, supra note 70, at 322.

137. Early in his career as a federal circuit judge, Taft clearly perceived that "[t]he railroads have become as necessary to life and health and comfort of the people of this country as are the arteries on the human body." Thomas v. Cincinnati, N.O. \& T.P. Ry. Co., 62 F. 803, 821 (C.C.S.D. Ohio 1894). In 1917, Taft had argued that the best method to improve the health of the railway system was by imcorporating the "railways under federal law and taking them out from under the nagging supervision of state commission supervision." WILLIAM HOWARD TAFT, Our Railway Situation, in COLLECTED EDITORIALS, supra note 18, at 20. Taft believed that the poor condition of the railroads was due to "the hostile blundering, greed, and jealousy" of state legislatures," and he advocated "the complete taking over of the interstate comineree business of the country into the regulation of the Interstate Commerce Commission." Taft, Federal Power, supra note 109, at 72-73. He fully anticipated that such a solution would "cause a great deal of local opposition by the enormous inachinery that has now been created for the intra-state regulation.... The state [railroad] commissioners have already organized with a view to protection of their jurisdiction." Id. at 72.

138. R.R. Comm'n, 257 U.S. at 588.

139. Id. at 585. Taft's opinion rested on the "far-reaching" conclusion "that the transportation systems of the country are not divided by the boundaries of the states but are nation-wide institutions to be dealt with in the interest of the country as a whole." Parker McCollester, Regulation of Intrastate Commerce Under the Commerce Clause, 31 YALE. LJ. 870, 878 (1922).

140. Editorial, States' Rights and Railroad Rates, WALL ST. J., Mar. 1, 1922, at 1. The Wall Street Journal cousidered the decision "one of the most inportant that the Supreme Court has rendered in recent years." Suprente Court Upholds Federal Rate-Making Power, WALL ST. J., Feb. 28, 1922, at 6. 
transporting the products of the farms, mines and forests to the centers of consumption and use in this country and to the seaboard, of carrying the products of mills, factories and industrial plans from the place of fabrication to the place of use, and so on and so on. ${ }^{141}$

Throughout the 1920s, the Taft Court would pursue a relentlessly nationahist agenda for the railroads, supporting the purpose of the Transportation Act "affirmatively to build up a system of railways prepared to handle promptly all the interstate traffic of the country" by putting

the railroad systems of the country more completely than ever under the fostering guardianship and control of the [ICC], which is to supervise their issue of securities, their car supply and distribution, their joint use of terminals, their construction of new lines, their abandonment of old limes, and by a proper division of joint rates, and by fixing adequate rates for interstate commerce, and in case of discrimination, for intrastate commerce, to secure a fair return upon the properties of the carriers engaged. ${ }^{142}$

\section{The "power of the states over traffic charges" was correspondingly reduced "to a shadow." 143}

141. Letter from Willis Van Devanter to William Howard Taft (n.d.), Taft Papers, supra note 104, Reel 249. Van Devanter remarked that he regarded

the opinion as a vital one, as of more importance than we now realize and as calculated to be a great factor in adjusting our present unbalanced and ill regulatcd transportation system to the imcreasing needs of the country and in ultimately placing it on a footing where it can serve all sections and all patrons at a ninimum of cost, inconverience and delay.... [W] plined, I apprehend that the rates will become less than anyone now would vcnture to predict.

Id.

142. Dayton-Goose Creek Ry. Co. v. United States, 263 U.S. 456, 478 (1924).

143. Note, The Waning Power of the States over Railroads: Curtailment of State Regulatory Activities by the Transportation Act, 37 HARV. L. REv. 888, 890 (1924); see, e.g., Chi., Milwaukee \& St. Paul Ry. Co. v. Pub. Utils. Comm'n, 274 U.S. 344, 350-52 (1927) (holding that a state commission, without any evidentiary foundation, improperly based its decision to reduce intrastate railroad rates on a decision by the ICC to lower interstate rates it found to be too high); N.Y. Cent. R.R. Co. v. N.Y. \& Pa. Co., 271 U.S. 124, 125-26 (1926) (deciding that state authorities could not grant reparations to a railroad when a federal statute forbade the reduction of railroad rates for six months after the end of federal controls unless approved by the ICC); R.R. Comm'n v. E. Tex. R.R. Co., 264 U.S. 79, 84, 90 (1924) (determining that attempts by the state to prohibit a failed railroad from disniantling its salvageable property because the railrond still had four and a half years of state imcorporation left were inpermissible under the applicable statute); Nashville, Chattanooga \& St. Louis Ry. v. Tennessee, 262 U.S. 318, 320, 323 (1923) (permitting the ICC to authorize a general nicrease in railway shipping rates, while denying the Railroad and Public Utilities Commission of Tennessee permission to decrease the rates for carriers of materials to build public roads). Brandeis, however, was intermittently conccrned to search for procedural and political accommodations that inight ease the teusion between para- 
Although state regulation was permitted in the insignificant interstices of the rail system, ${ }^{1+4}$ state railroad commissions were even rendered powerless to prevent ICC-sanctioned abandonments of intrastate traffic along "physically detached" lines entirely within a state, so long as the lines were "operated in both intrastate and inter-

mount federal power and local state interests. See, eg., Ark. R.R. Comm'n v. Chi, Rock Island, \& Pac. R.R. Co., 274 U.S. 597, 599, 603 (1927):

The Railroad concedes that States have the exclusive right to fix intrastate rates, subject to the limitation that such rates must not unduly discriminate against interstate commerce; that a mere difference in rate does not constitute an undue discrimination; that the question whether discrimination exists is one for the Interstate Commerce Commission; that to justify federal interference there must be substantial disparity resulting in real discrimination; and that the extent of the alleged discrimination must be found in the federal commission's order. It contends that the Interstate Commerce Commission found that the existing intrastate class and commodity tariff discriminated unjustly against interstate commerce; that it ordered the removal of the discrimination; and that the Railroad had, therefore, the right and the duty to substitute a new non-discriminating tariff. The answer of the state commission is a denial that the federal commission made such finding or order....

The intention to interfere with the state function of regulating intrastate rates is not to be presumed. Where there is a serious doubt whether an order of the Interstate Commerce Commission extends to intrastate rates, the doubt should be resolved in favor of the state power. If, as the Railroad believed, the federal commission intended to include the intrastate Arkansas rates within its order, it should have taken action, through appropriate application, to remove the doubt by securing an expression by that commission of the intention so to do.

Taft commented on a draft of Brandeis's opinion in Chicago, Rock Island, \& Pacific Railroal Co. that "[w]e are teaching" three-judge courts "a little sense of propriety as 10 dcaling with state courts." William Howard Taft, Annotation to Circulated Draft Opinion in Arkansas Railroad Commission v. Chicago, Rock Island, \& Pacific Railroad Co., Brandeis Papers, supra note 116. For further discussion of Brandeis's efforts to reconcile national and state power, see also infra note 146.

144. See, eg., Mo. Pac. R.R. v. Boone, 270 U.S. 466 (1926) (allowing states some latitude to determine railroad rates and fares); W. \& Atl. R.R. v. Ga. Pub. Scrv. Comm'n, 267 U.S. 493 (1925) (giving states the right to require railroads to furnish switching service for shippers); Norfolk \& W. Ry. Co. v. Pub. Serv. Comm'n, 265 U.S. 70 (1924) (permitting states to require railroad carriers to provide the necessary facilities to allow shippers to remove freight carried on the railroad). For an example of the Court earnestly wrestling with the question of whether a state-ordered gradecrossing was too expeusive, see Lehigh Valley R.R. Co. v. Bd. of Pub. Util. Comm'rs, 278 U.S. 24, 35 (1928):

The care of grade crossings is peculiarly within the police power of the States, Railroad Comm'n v. Southern Pacific Co., 264 U.S. 331, 341; and if it is seriously contended that the cost of this grade crossing is sueh as to interfere with or impair economical management of the railroad, this should be made clear. It was certainly not intended by the Transportation Act to take from the States, or to thrust upon the Interstate Commerce Commission, investigation imto parochial inatters fike this, unless, by reason of their effect on economical management and service, their general bearing is clear. Railroad Commission v. Southern Pacific Co., 264 U.S. 331. The latter case makes a distinction between the local character of the usual climination of grade crossings and the vital character froin the standpoint of finance of the investment of large sums in the erection of a Union Station. 
state commerce as a part of the system by means of connections with other railroads." ${ }^{145}$ The Court announced that federal power was justified because the "[e]fficient performance" of either interstate or intrastate commerce "is dependent upon the efficient performance of the transportation system as a whole. ${ }^{.146}$

145. Colorado v. United States, 271 U.S. 153, 159-60 (1926).

146. Id. at 164 . The Court's opinion was authored by Brandeis, who relegated state railroad commissions to the essentially political remedies of consultation and petition:

As every projected abandonment of any part of a railroad engaged in both interstate and intrastate commerce nuay conceivably involve a conflict between state and national interests, the consent of the Commission must be obtained by the railroad in every case. To ensure due consideration of the local interests, Congress provided that a copy of every application must be promptly filed with the Governor of the State directly affected, that notice of the application nutust be published in some local nowspaper, and that the appropriate state authorities should have "the right to make before the Commission such representations as they may deem just and proper for preserving the rights and interests of their people and the States, respectively, involved in such proceedings." In practice, representatives of state regulatory bodies sit, sometimes, with the representatives of the Commission at hearings upon the application for a certificate. Occasionally, the Commission leaves the preliminary enquiry to the state body. And always consideration is given by the Commission to the reprosentations of the state authorities.

Id. at 167. Brandeis elsewhere appealed to the notion that "nice adjustments" would be requircd to reconcile federal and state regulatory power over railroads. See, e.g., Lawrence v. St. LouisS.F. Ry. Co., 274 U.S. 588, 594-95 (1927):

[T] he fact is important that the controversy concerns the respective powers of the Nation and of the States over railroads engaged in interstate commerce. Such railroads are subject to regulation by both the State and the United States. The dolinitation of the respective powers of the two governments requires often nice adjustments. The federal power is paramount. But public interest deinands that, whenever possible, conflict between the two authorities and irritation be avoided. To this end it is important that the federal power be not exerted unnecessarily, hastily, or harshly. It is important also that the deinands of coinity and courtesy, as well as of the law, be doferred to. It was said in Western \& Atlantic R. R. v. Georgia Public Service Commission, 267 U.S. 493, 496, that a law of a State may be valid which prohibits an important change in local transportation conditions without application to the state commission, although the ultimate authority to determine whether the change could or should be nuade may rest with the federal commission. And it was there said that the "action of the Coinpany in discontinuing the service without a petition" to the state body was "arbitrary and defiant." Compare Henderson Water Co. v. Corporation Commission, 269 U.S. 278. To require that the regulating body of the State be advised of a proposed change seriously affecting transportation conditions is not such an obvious interference with interstate commerce that on application for a preliminary imjunction the Act should hightly be assunied to bo beyond the power of the State.

See also St. Louis-S.F. Ry. Co. v. Ala. Pub. Serv. Comm'n, 279 U.S. 560 (1929) (holding that an niterstate railroad must first comply with the terms of an Alabama statute before it could chal-

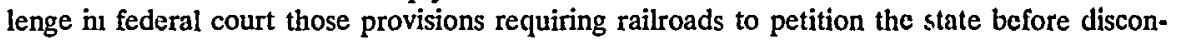
tinuing any railroad service within the state). 
The ferocious nationalism of the Court's treatment of railroads, ${ }^{157}$ a nationalism that exceeded the narrow bounds of the Transportation Act, ${ }^{148}$ no doubt im part reflected the specific wartime experience of

147. See, e.g., United States v. Ill. Cent. R.R. Co., 263 U.S. 515, 525 (1924) (upholding the ICC's decisions on the ground that the interests of individual carriers must yield to the public need); St. Louis-S.F. Ry. Co. v. Pub. Serv. Comm'n, 261 U.S. 369, 372 (1923) (cautioning that any exercise of state authority which directly regulated interstate commerce was repugnant to the Constitution); The New England Divisions Case, 261 U.S. 184, 189-90 (1923) (highlighting Congress's unequivocal purpose in passing the Transportation Act of 1920 to preserve the financial integrity of national railway transportation); Pa. R.R. Co. v. U.S. R.R. Labor Bd., 261 U.S. 72, 79-80 (1923) (enphasizing that Congress has deemed it of high public importance to prevent labor disputes froin interrupting interstate commeroe). In Alabama \& Vicksburg Railway Co. v. Jackson \& Eastern Railway Co., 271 U.S. 244 (1926), the Court, in an opinion by Brandeis, held that state courts were without power to authorize a railroad to cxereise eminent domain for the purpose of creating a junction with another railroad, even if a state court had held that "the proposed connection was a proper one" and that "the authority granted by the state law to secure junctions did not interfere with interstate commerce to an appreciable degree, if at all." Id. at 247. Brandeis conceded that the Court had earlier permitted such state determinations in Wisconsin, Minnesota \& Pacific Railroad Co. v. Jacobson, 179 U.S. 287 (1900), but noted that "[s]ince then the authority of the Interstate Commerce Commission has been greatly enlarged and the power of the States over interstate carriers correspondingly restricted." Ala. \& Vicksburg Ry. Co., 271 U.S. at 248.

The only limitation set by Transportation Act, 1920, upon the broad powers conferred upon the Commission over the construction, extension and abandonment of the lines of carriers in interstate commerce, is that introduced as paragraph 22 of $\$ 1$, which excludes froin its jurisdiction "spur, industrial, team, switching or side tracks, located wholly within one State, or of street, suburban, or imterurban electric railways, which are not operated as a part or parts of a general steam railroad system of transportation." It is clear that the connection here in question is not a track of this character.

Id. at 249. The Court accordingly held that the jurisdiction of the 1CC was "exclusive." Ill. at 250. Responding to Brandeis's draft opinion, Taft wrote, "I concur. After a while you will get into the minds of state courts that the I.C.C. really exercises some authority." William Howard Taft, Annotation to Circulated Draft Opinion in Alabama \& Vicksburg Railway. Co. v. Jackson \& Eastern Railway Co., Brandeis Papers, supra note 116.

148. See, e.g., Midland Valley R.R. v. Barkley, 276 U.S. 482, 487 (1928) (declaring that, where Congress chose to regulate the distribution of coal cars, it thereby abrogated state rules in this field); Davis v. Wechsler, 263 U.S. 22, 24 (1923) (emphasizing that state courts may never allow local rules to defeat a federal right); Am. Ry. Express v. Levec, 263 U.S. 19, 21 (1923) (holding that a local rule regarding the burden of proof contravened federal law and was therefore invalid). Particularly inuportant were a line of cases, developed by Brandeis, which prohibited under the dormant Commerce Clause state courts from assuming jurisdiction over tort suits against interstate railroads when the cause of action did not arise within the forum state, when the defendant did not own or operate a railroad within the form state, and when the plaintiff was also a nonresident of the forum state. See Davis v. Farmers Co-Operative Equity Co., 262 U.S. 312, 317 (1923):

[O]rderly, effective administration of justice clearly does not require that a foreign carrier shall subinit to a suit in a State in which the cause of action did not arise, in which the transaction giving rise to it was not entered upon, in which the carrier neither owns nor operates a railroad, and in which the plaintiff does not reside. The public and the carriers are alike interested in maintaining adequate, uninterrupted transportation service at reasonable cost. This common interest is emphasized by Transportation Act, 1920, which authorizes rate increases necessary to ensure to car- 
riers efficiently operated a fair return on property devoted to the public use. See Railroad Commission of Wisconsin v. Chicago, Burlington \& Quincy R.R. Co., 257 U.S. 563; New England Divisions Case, 261 U.S. 184. Avoidance of waste, in interstate transportation, as well as maintenance of service, has become a direct concern of the public. With these ends the Minnesota statute, as here applied, unduly interferes. By requiring from interstate carriers general submission to suit, it unreasonably obstructs, and unduly burdens, interstate commerce.

See also Mich. Cent. R.R. Co. v. Mix, 278 U.S. 492, 495 (1929) (holding that a plaintiff could not subject a nonresident corporation to suit in a state where she had acquired residence after the accident had occurred); Atchison, Topeka \& Santa Fe Ry. Co. v. Wells, 265 U.S. 101, 103 (1924) (declaring invalid a Texas statute which permitted a nonresident to prosecute an out-of-state railroad corporation for an accident that occurred in another state). But see Hoffman va Missouri ex rel. Foraker, 274 U.S. 21, 22-23 (1927) (holding that, if a railroad company is sued where it owns, operates, and carries out its business, then it must comply); Chicago \& Nortlwestern Ry. Co. v. Alvin R. Durham Co., 271 U.S. 251, 258 (1924) (holding that the liability of a garnishee is fixed by state, not federal, law); Missouri ex rel. St. Louis, Brownsville \& Mcx. Ry. Co. v. Taylor, 266 U.S. 200, 207 (1924) (ruling that, where a railway carrier has a usual place of business in a state and the alleged negligence occurred there, it is amenable to suit in that state); EDWARd A. Purcell, JR., Litigation and INequality: Federal Diversity JURISDICTION IN INDUSTRIAL AMERICA, 1870-1958, at 193-96 (1992) (discussing Justice Brandcis's support of devices like the Commerce Clause venue doctrine because they allowed federal courts to regulate nationwide forum use based on practical considerations); Bernard C. Gavit, Jurisdiction over Causes of Action Against Interstate Carriers, 3 IND. L.J. 130, 137 (1927) (concluding that federal legislation may be needed to govern the venue of actions against interstate carriers).

The Taft Court also frequently interpreted federal statutes regulating railroads as preempting and displacing state law. In Napier v. Atlantic Coast Line Railroad Co., 272 U.S، 605 (1926), for example, Brandeis held for a unamimous Court that the Boiler Inspection Act, Pub. L. No. 61-383, ch. 103, 36 Stat. 913 (1911), had "occupied the field of regulating locomotive equipment used on a highway of interstate commerce, so as to preclude state legislation." Napier, 272 U.S. at 607. Even though federal regulators had not ruled under the Act that interstate railroads had to obtaim "a particular type of fire box door or a cab curtain," icl. at 609, Brandeis nevertheless upheld a federal court imjunction prohibiting enforcement of state statutes requiring these safety devices, even assuming that "there [was] no physical conflict betwcen the devices required by the State and those specifically prescribed by Congress or the Interstate Commerce Commission," and that the required state deviccs actually "promote[d] safety," $i d_{\text {. at }}$ 610-611. "[R] equirements by the States are precluded, however commendable or however different their purpose.... If the protection now afforded by the Commission's rules is deemed inadequate, application for rehef must be made to it." Id. at 613. One local paper complaincd that the decision

seeins to us going a bit too far, and is just another example of the startling and overmastering incursion of Federal power in this land. If we inust depend upon the Congress to regulate the equipment of the B. \& $O$. yards in Grafton, we have come to a dangerous place in American law and its administration.

Editorial, A Real Danger, Grafton (West Virginia) SENTINel, Dec. 2, 1926, at 4. Brandeis, however, wrote to Frankfurter the day after the decision:

In [Napier] I have endeavored to make clear, as a matter of statutory construction, the "occupying the field" doctrine. I think the states could be taught, by a similar $\mathrm{ABC}$ article that, if they wish to preserve their police power, they should, through the "state block" in Congress, see to it in every class of Congressional legislation that the state rights which they desire to preserve be expressly provided for in the acts.

"HALF BROTHER, HALF SON": THE LETTERS OF LOUIS D. BRANDEIS TO FELIX FRANKFURTER 263 (Melvin I. Urofsky \& David W. Levy eds., 1991) [hereinafter BRANDEIS- 
federal control over the country's railway system. ${ }^{\text {1.9 }}$ But the essential point is that this experience had brought home to the Court the thought that "[i]n solving the problem of maintaining the efficiency of an interstate commerce railway system which serves both the States and the Nation, Congress is dealing with a unit in which state and interstate operations are often mextricably commingled."150 The Court saw interstate and intrastate railroad transportation as an interdependent system, fused into a single "umit." It was this perception of national integration that precluded the possibility of carving railroad transportation into distinct and exclusive state and federal spheres of sovereignty.

An analogous apprehension of national integration is evident in several Taft Court opinions that address other aspects of the national market. A good example is Stafford $v$. Wallace, ${ }^{151}$ which upheld the Packers and Stockyards Act of 1921. Exphicitly drawing on the "close

FRANKFURTER LETTERS]; see also Chesapeake \& Ohio Ry. Co. v. Stapleton, 279 U.S. 587, 593 (1929) (declaring that, where the field is relations between an interstate carrier and its interstate employees, it is exclusively a federal question); Mo. Pac. R.R. Co. v. Porter, 273 U.S. 341, 346 (1927) (holding that, where Congress has entered a field of regulation, state laws have no application); Chi., Milwaukee \& St. Paul Ry. Co. v. Coogan, 271 U.S. 472, 474 (1926) (stating that Congress preempted state law on employers' liability to employees in interstate transportation by rail when it passed the Federal Employers' Liability Act).

149. Many of the Court's opinions include direct references to the period of federal control. See, e.g., United States v. Reading Co., 270 U.S. 320, 330 (1926) (holding the federal government tiable for charges it erroneously collected from railway carriers under the Federal Control Act); Marion \& Rye Valley Ry. Co. v. United States, 270 U.S. 280, 282 (1926) (stating that no compensation was due where the taking of a railroad under the Federal Control Act was not implemented); Davis v. Wechsler, 263 U.S. 22, 24 (1923) (holding that state courts may not defeat federal rights by applying local rules); Wabash Ry. Co. v. Elliotl, 261 U.S. 457, 463 (1923) (ruling that no liability can attach for personal injury where a railway company is under federal control); Davis v. L.N. Dantzler Lumber Co., 261 U.S. 280, 289 (1923) (holding that a railroad under federal control could not be subject to garnishment in state court); N.C. R.R. Co. v. Lee, 260 U.S. 16, 17 (1922) (holding that the federal government was operating a North Carolina railway not as a lessee but by right of eminent domain); see also Marvin B. Rosenberry, Development of the Federal Idea, 218 N. AM. REV. 145, 158 (1923):

During the World War, the Federal Government took over the operation of the railway and telegraph systems as a war measure. It is already apparent that this step is to have a far-reaching effect upon the transportation systems of the country. The advantages of unified control, direct routing and free exchange of equipment are so manifest .... The decision of the Urited States Supreme Court in Railroad Commission vs. C. B. \& Q. Ry. Co.... indicates quite clearly that every transportation agency in the country is likely to be drawn into the Federal system, with the power and authority of the agents of the Federal Government vastly extended. Already the power of the States to regulate intra-state transportation is greatly limited.

150. Dayton-Goose Creek Ry. Co. v. United States, 263 U.S. 456, 485 (1924).

151. 258 U.S. 495 (1922). McReynolds dissented without opinion; Day did not participate in the case. 
analogy" of the Transportation Act of $1920,{ }^{152}$ the Court, speaking through Taft, concluded that "it was one of the chief purposes of the Constitution to bring under national protection and control" the "ever flowing" "streams of commerce" that connect "one part of the country to another." 153 Although Stafford is sometimes seen as merely an extension of the "current of commerce" approach of Swift \& Co. v. United States, ${ }^{154} \mathrm{~m}$ fact it marked a significant departure from Swift. Swift turned on the imtent of particular persons to restrain and monopolize interstate commerce. Stafford, by contrast, concerned the facial constitutionahty of a statute and did not involve the application of legislation to particular persons and transactions. ${ }^{155}$

152. Id. at 522-23. The Court specifically cited Railroad Commission v. Chicago, Burlinglon \& Quincy Railroad Co., 257 U.S. 563 (1922), for the proposition that "intrastate transactions that affect prejudicially interstate commerce" could be regulated by Congress. Id. at 523 .

153. Stafford, 258 U.S. at 518-19. Taft sent a draft of his opinion to Van Devanter and Clarke for review, "because we are very clear in our judgment, and I would like the benefit of your criticism before I send it on to other members of the Court who are more doubtful." Letter from William Howard Taft to Willis Vau Devanter (Apr. 20, 1922), Van Devanter Papers, stupra note 116; Letter froin Williain Howard Taft to John Hessin Clarke (Apr. 20, 1922), Taft Papers, supra note 104, Reel 241 . When Taft finally circulated his draft, Brandeis replied, "This is very strongly put and has converted ine." Louis D. Brandeis, Annotation to Circulated Draft Opin. ion in Stafford v. Wallace, id., Reel 615. Holmes responded, "Admirable and big." Oliver Wendell Holmes, id. Hohnes thought the opinion "expressed the movement of interstate com. inerce in a large aud rather inasterly way." HOLMES-POLLOCK LETTERS, stupra note 81, at 96; see also HOLMES AND FRANKFURTER: THEIR CORRESPONDENCE, supra note 70, at 140 ("I think the C.J.'s opinion as to commission inerchants and dealers in stock yards is fine. It has a sort of march, like the inoveinent of interstate commerce that it describes."); 1 HOLMES-LASKI LETTERS: THE CORRESPONDENCE OF MR. JUSTICE HOLMES AND HAROLD J. LASK1, 19161935, at 423 (Mark DeWolfe Howe ed., 1953) [heremafter HOLMES-LASK1 LETTERS]:

Taft continues to give me great satisfaction as C.J. He delivered a decision last Monday on the power of Congress to deal with commission merchants and dealers in the Stock Yards that had a kind of big movement in it parallel to the interstate trade he sought to portray. Also he is anniable and comfortable.

Clarke had writteu to Taft about an early draft of the opinion that

You are exceedingly happy I think in describing the movement involved as in sub. stance a single one from the producing farmers in the west to the consuming and expecting cities in the East. That is what it really is and it will be an addition to the law to have it clearly stated \& recognized in practice. This [illegible] character of the inovement subordmates separate incidents which seem local to the inain purpose or intent.

Letter froin John Hessin Clarke to William Howard Taft (n.d.), Taft Papers, supra note 104, Reel 249.

154. 196 U.S. 375, 398-99 (1905); see Earl L. Shoup, The Life and Times of William Howard Taft by Henry F. Pringle, 26 WASH. U. L.Q. 142, 146 (1940) (book review).

155. Clarke was quite clearly troubled by this difference. He wrote to Taft that

I really doubt the soundness of the expression ... that the Act of Congress can supply the equivalent of intent in the conduct of the parties themselves which led to the conclusion in the Swift case. Must not the intent be found in the conduct dealt with? That binds it together so that the courts will not dissect it and affirm or condemn its separate elements but will deal with the transaction as a comprehensive whole. The fact is 
Stafford squarely addressed the constitutional authority of Congress to regulate transactions heretofore understood to reside in the exclusive domain of state police power. It held that "[t]he reasonable fear by Congress" that a course of conduct "usually lawful and affecting only intrastate commerce when considered alone, will probably and more or less constantly be used in conspiracies against interstate commerce or constitute a direct and undue burden on it," could serve "the same purpose as the imtent charged in the Swift indictment to bring acts of a similar character imto the current of interstate commerce for federal restraint.,"156 Forging a highly nationalist perspective, ${ }^{17}$ Taft stressed the deference owed to Congress in determining whether intrastate transactions should be characterized as burdening imterstate commerce:

Whatever amounts to more or less constant practice, and threatens to obstruct or unduly to burden the freedom of interstate commerce is within the regulatory power of Congress under the commerce clause, and it is primarily for Congress to consider and decide the fact of the danger and meet it. This court will certainly not substitute its judgment for that of Congress in such a matter unless the relation of the subject to interstate commerce and its effect upon it are clearly non-existent. ${ }^{158}$

there's something of finessing to be done in this case and you are so much more capable of that kind of thinking than I am that I am sure I couldn't be of service if I should try by writing a volume.

Letter froin John Hessin Clarke to Williaun Howard Taft (n.d.), Taft Papers, supra note 104, Reel 249 (emphasis added).

156. Stafford, 258 U.S. at $520-21$.

157. It has been said that Taft's opinions staking out liberal interpretations of congressional power under the Commerce Clause mark "his most successful and influential work as Chiel Justice." Stanley I. Kutler, Chief Justice Taft, National Regulation, and the Commerce Powver, $51 \mathrm{~J}$. AM. HIST. 651, 651 (1965); see also Alpheus T. Mason, William Howard Tafi, 1857-1930, 334 ILL. L. REV. 884, 886 (1940) (stating that Taft's inost notable contributions to constitutional law are in his interstate commerce cases). Taft repeatedly expressed his admiration for John Marshall, "the greatest Judge that America or the World has produced," WILLIAM HOWARD TAFT, POPULAR GOVERNMENT: ITS ESSENCE, ITS PERMANENCE AND ITS PERILS 131 (1913) [hereinafter TAFT, POPULAR GOVERNMENT], because Marshall set the course of the Court toward a "liberal construction of the Constitution in conferring powers upon the National Government" and against "the scliool of Jefferson" that would have "emphasize[d] unduly the sovereignty of the States." Id. at 133-37; see also William Howard Taft, Address Before the National Civic Federation at the Belasco Theatre, Washington D.C. (Jan. 17, 1910), in 1 PREsIDENTIAL ADDRESSES AND STATE PAPERS 550 (1910) [hereinafter Taft, Address] (attributing the reason we have a strong nation and a centralized government to the wisdom and vision of John Marsliall); William Howard Taft, Criticisms of the Federal Judiciary, 29 AN. L. REV. 641, 645 (1895).

158. Stafford, 258 U.S. at 521 . A month later, Taft summarized the holdings of Stafford and the Wisconsin rate case this way: 
In essence, Stafford ceded to Congress constitutional latitude to determine when interstate and intrastate commerce were so intermimgled as to be regarded as a "unit." with the basic thrust of dual sovereignty in at least two respects. First, it authorized congressional regulation of specific spheres of social life previously reserved for the "exclusive" regulation of the states. Second, it effectively authorized Congress to determine when such regulation was justified. Stafford advanced these innovations in order to assure the adequacy of federal power to safeguard a national market characterized by "modern conditions," 160 in which local and national transactions were thoroughly integrated. This was a significant departure from the sensibility of E.C. Knight.

\section{B. Congressional Power and the Logic of Dual Sovereignty}

Although the Taft Court expanded the reach of Congress's commerce power, it by no neans abandoned the logic of dual sovereignty. As we have already seen in our discussion of the Court's antitrust jurisprudence, ${ }^{161}$ the principles of dual sovereignty remained influential. In fact in his very first Term Taft authored a highly

It is clear ... that if Congress deems certain recurring practices, though not really part of imterstate commerce, likely to obstruct, restrain or burden it, it has the power to subject thein to national supervision and restraint.

United Mine Workers v. Coronado Coal Co., 259 U.S. 344, 408 (1922).

159. Several years later, in Atlantic Coast Line Railroad Co. v. Standard Oil Co., 275 U.S. 257 (1927), which concerned the question of whether shipinents of oil should be charged at interstate or intrastate rates, the Court was quite exphicit that the "streain of commerce" nietaphor of Stafford should not be taken as a literal definition of the scope of interstate cominerce. Instead, the Court explained, Stafford

held that a reasonable fear upon the part of Congress, that acts usually affeeting only intrastate commerce when occurring alone, would probably and more or less constantly be performed in aid of conspiracies against interstate commerce, or constitute a direct and undue obstruction and restraint of it, would serve to bring such acts within lawful Federal statutory restraimt.

Id. at 272. Thus Stafford "can not be cited to show what is interstate and what is intrastate commerce im a controversy over rates to determine whether they come normally within the regulation of Federal or State authority." Id. at 273; see United Leather Workers Int'l Union v. Herkert \& Meisel Trunk Co., 265 U.S. 457, 469 (1924) (noting that Stafford does not establish "that a strike against the manufacturer of commodities intended to be shipped in interstate commerce is a conspiracy against that commerce" and that Stafford held that Congress can regulate what it finds to be "abusive practices ... usually only within state police cognizance" that threaten to "obstruct or unduly to burden" interstate commerce). Stafford was thus an opinion addressed to congressional authority to define the boundaries of its own power.

160. 258 U.S. at 518.

161. See supra notes $97-104$ and accompanying text. 
controversial opinion in the case of Bailey v. Drexel Furniture Co. ${ }^{162}$ that forcefully articulated these principles. The decision struck down the child labor tax statute ${ }^{163}$ which Congress had enacted to reinstate the prohibitions of the Keating-Oweu Child Labor Law invalidated in Hammer v. Dagenhart. ${ }^{164}$ The child labor tax statute imposed an excise

162. 259 U.S. 20 (1922). For a summary of press reactions, sec The Child-Labor Quashed, 73 LITERARY DIG., May 27, 1922, at 11.

163. Revenue Act of 1918 , Pub. L. No. $65-254$, $\S \S 1200-1207,40$ Stat. $1057,1138-40$ (1919). Taft's opinion was joined by all of the Justices except Clarkc, who dissented without opinion. Clarke would later observe to Woodrow Wilson that the case was "unfortunately" ... considered and decided when one of my sisters was dying and I could not write a dissenting opinion. I am sure a dissent based on the decisions from the oleomargarine to the Narcotic Drug Cases could have been made very convincing." Letter from John Hessin Clarkc to Woodrow Wilson (Sept. 9, 1922), Woodrow Wilson Papers, Mudd Library, Princeton University, Princeton, Ncw Jersey, Reel 122 [hereinafter Wilson Papers]. By contrast, Brandeis had written to Taft that Bailey was "a very good opinion," "clear and forceful," and that Taft had "done all that can be done to distinguish the earlier cases." Louis D. Brandeis, Annotation to Circulated Draft Opinion in Bailey" v. Drexel Furniture Co., Taft Papers, supra note 104, Reel 614. Brandeis wrote to Frankfurter that

The N[ew] R[epublic], The Survey \& like periodicals should not be permitted to misunderstand yesterday's decision on The Child Labor and Board of Trade cases, \& sloould be made to see that holding these Acts void is wholly unlike holding invalid the ordinary welfare legislation.

That is - that we here deal

(1) With distribution of functions between State \& Fedcral Governments

(2) With the attempt at dishonest use of the taxing powers.

Letter from Louis Brandeis to Felix Frankfurter (May 16, 1922), in BRANDEIS-FraNkFURTER LETTERS, supra note 148, at 100-01. Brandeis's condemnation of the "dishonest use of the taxing powers" should be contrasted to his pre-ivar recommendation that Congress use the pretext of its taxing power to regulate state banks and insurance companics. See LoUIS D. BRANDEIS, OTHER PEOPLE'S MONEY AND HOW THE BANKERS USE 1T 60-61 (1933) ("While Congress has not been granted power to regulate directly statc banks, and trust or life insurance companies... except in respect to interstate commerce, it may do so indirealy by virtuc either of its control of the mail privilege or through the taxing power."). (I am grateful to Edward Purcell for this reference.) Brandeis's mention of the "Board of Trade cases" refers to the fact that Bailey was decided on the same day as Hill v. Wallace, 259 U.S. 44 (1922), which struck down a section of the Futures Trading Act of August 24, 1921, ch. 86, 42 Stat. 187. See infra notes 17077 and accompanying text. For a discussion of Brandeis's vote in Bailey, see WOOD, supra note 22 , at $292-93$.

164. 247 U.S. 251 (1918). The Keating-Owen Law had prohibited the products of child labor from being shipped in interstate commerce. Taft opposed the Keating-Owen Law, arguing that "the use by Congress of the power of interstate commerce as a club to control the states, in the character of the police ineasures that they shall adopt in their own internal affairs, is a dcparture from its previous course that may well give great concern." Taft, Federal Power, supra note 109, at 75. Taft reasoned that although Congress ought to be able to regulate interstate commerce "for the purpose of promoting or limiting commerce as a vehicle to proper objects," it should not be permitted to regulate interstate commerce "for the purpose of putting the states under duress to adopt a police policy in matters over which they have by the Constitution complete control." Id. at 76. Although the Court in Dagenhart did not accept Taft's invitation to delve into the motives of Congress, Taft nevertheless applauded the decision. See WILLIAM HowARD TAFT, Child-Labor Legislation, in COLLECTED EDrTORIALS, supra note 18, at $69-70$ ("In mat- 
tax of ten percent on most employers who used child labor. The Court reasoned that because the regulation of such employers was "reserved" to the "States ... by the Tenth Amendment," the use of federal taxing power to usurp this authority would "break down all constitutional limitation of the powers of Congress and completely wipe out the sovereignty of the States."165

Bailey sparked immediate and fierce opposition, not only prompting calls for a constitutional amendment authorizing federal regulation of child labor, ${ }^{166}$ but also for a constitutional amendment to

ters imtrusted to the states by the Constitution, we must look to the states for proper laws and their effective enforcement. To do otherwise is to confess our national system a failure."); $c f$. TAFT, POPULAR GOVERNMENT, supra note 157, at 142-43:

Child labor in the State of the shipment has no legitimate or germane relation to the interstate commerce of which the goods thus made are to form a part, to its character or to its effect. Such an attempt of Congress to use its power of regulating such commerce to suppress the use of child labor in the State of shipment would be a clear usurpation of that State's rights.

Taft, Address, supra note 157, at 552 (arguing that the federal government cannot carry out all reform and that the states also carry a heavy responsibility); Robert C. Post, Chief Justice Wil. liam Howard Taft and the Concept of Federalism, 9 CONST. COMMENT. 199, 205-08 (1992) (discussing the tension between Taft's expansive view of federal power and his impulse to restrict federal regulation of some interstate activities). After Dagenhart, the Senate sought to revive the Keating-Owen prohibitions "as a war measure," A New Campaign Against Child Labor, 120 OUTLOOK 518, 518 (1918), but the Armistice caused the Act's supporters instead to formulate a federal law that taxed the use of child labor. The full story is told in Mark E. Herrmann, Note, Looking Down from the Hill: Factors Determining the Success of Congressional Efforts to Reverse Supreme Court Interpretations of the Constitution, 33 WM. \& MARY L. REV. 543, 547-564 (1992) (reviewing Congress's four attempts to craft federal child labor regulations), and in WOOD, supra note 22 (recounting the struggle to establish national child labor standards during the Progressive Era).

165. Child Labor Tax Case, 259 U.S. 20, 38 (1922). After the decision, James M. Beck, the Solicitor General who had defended the child labor tax law, and who was in his personal beliefs a strong defender of states' rights, see JAMES M. BECK, THE VANISHING RIGHTS OF THE STATES 14 (1926), wrote Taft to confess that

none who heard you deliver the opimion may have welcomed the decision more than I. Had the Court adhered tenaciously to the views of the late Chief Justice White in McCray v. United States, our form of Government would have sustained a serious injury.

Letter froin James M. Beck to William Howard Taft (May 16, 1922), Taft Papers, supra note 104, Reel 242. Taft replied that "I had an impression that your soul was not wrapped up in the Child Labor cases." Letter froin William Howard Taft to James M. Beck (May 17, 1922), id. Taft later reinarked that he "hoped that the judgment supported by the opinion of eight Judges would have some effect to stop the tendency of Congress to seek to give to the Federal Government that which under the Constitution really belongs to the States." Letter from William Howard Taft to Henry St. George Tucker (Sept. 27, 1922), id., Reel 245.

166. Sanuel Gompers, Editorial, Let Us Save the Children, 29 AM. FEDERATIONIST 413, 413-14 (1922) ("The Supreme Court deals with childhood exactly as it would deal with pig iron .... [A] constitutional amendment is needed to complete the work quickly. The Supreme Court can not reach and destroy a constitutional amendment."); Will Fight to Save Children from Toil: Federation of Labor Plans an Active Campaign for a Constitutional Amendment, N.Y. 
strip the Supreme Court of the power to declare congressional statutes unconstitutional. ${ }^{167}$ The decision was defended, however, by those who opposed the transformation of "our Federal system ... into a centralized governmental machine, with the States of little more significance than counties are now." ${ }^{\text {"165 }}$ Taft took the occasion in

TIMES, May 26, 1922, at 20 (reporting that the American Federation of Labor planned to make an amendment to prevent child labor its top election issue). Taft himself opposed the effort to enact a constitutional amendment authorizing federal regulation of child labor:

I don't know how you feel about the child labor amendment, but the more I have thought of it, the more convinced I have been that it would be a mistake to pass it. I think the southern States are getting into better shape with reference to child labor laws, and that the two centers of activity in favor of adopting the amendment are the labor unions and those good people who have no hesitation in changing the Constitution and shifting all the burdens of executing laws to the National Government whenever there is any doubt as to their enforcement, and whenever they happen to be particularly interested in enforcement. I think the centralization that hes been going on has been greatly detrimental to our constitutional structure ....

Letter froun William Howard Taft to Robert A. Taft (Dec. 22, 1924), Taft Papers, supra note 104, Reel 270 (emphasis added).

167. Is the Supreme Court Too Supreme?, LITERARY DIG., July 1, 1922, at 21 (compiling media reaction to protests that the Supreme Court should not have the power to deciare any law of Congress unconstitutional); La Follette Lashes Federal Judiciary, N.Y. TINIES, June 1S, 1922 , at 1 (reporting on Senator Robert M. La Follette's "nullification proposal," which would allow Congress to nullify any Supreune Court decision overturning congressional legislation); Robert M. La Follette, Supreme Court Ruler of Nation: Highest Tribunal Has Usurped Power to Nullify Laws, LA FOLLETTE'S MAG., June 1922, at 83 (discussing the need for a constitutional amendment in hight of the Supreme Court's actions); $c f$. Resolutions of the Grand Lodge of the Brotherhood of Railroad Trainmen (June 23, 1922), Taft Papers, supra note 104, Reel 243 ("Resolved, That this Third Trieunial Convention of the Brotherhood of Railroad Trainmen go on record in favor of having the Constitution of the Urited States so nmended that the positions of the judges of the Supreme Court and other Federal courts shall be elective instead of appointive ....").

168. Fabian Franklin, Why the Supreme Court Rejected the Child-Labor Law, 108 INDEPENDENT 507, 508 (1922).

That that system is worth preserving is not a dictate of mere conservatism; nor is it recommended solely by the sentiment which attaches to the tradition of State individuality, or aversion to unlimited centralized control in a vast and varied country like ours. For the initiative of the separate States has been a fruitful source of our social and governmental progress....

If, however, anything like the traditional autonoiny of our States in their home affairs is to be preserved, it will not do to look to the Supreme Court to save it from destruction.... If the people, or the Congress which the people choose as their representative, don't care a fig for the fundamental principles of the Constitution, ways will be found a-plenty to undermine those principles.... When the Prohibition amendment was adopted by Congress, many Representatives and Senators were perfectly aware of its monstrons inpropriety as part of our Federal Constitution, but few had the courage and unanliness to vote against it.... Yet it is to the couragcous assertion of fundamental principles that those of us inust look forward who still believe that the historic principles of American government are worth preserving. In the meanwhile, we unust be thankful to the Supreme Court not only for maintaining those principles when the Constitution warrants its interposition, but also for directing the nation's at- 
Bailey eloquently to remind the country that attempts to unduly expand congressional power, even to achieve good ends, could undermine the essential constitutional structure of the nation:

It is the high duty and function of this court in cases regularly brought to its bar to decline to recognize or enforce seeming laws of Congress, dealing with subjects not entrusted to Congress but left or committed by the supreme law of the land to the control of the States. We can not avoid the duty even though it require us to refuse to give effect to legislation designed to promote the highest good. The good sought in unconstitutional legislation is an insidious feature because it leads citizens and legislators of good purpose to promote it without thought of the serious breach it will make in the ark of our covenant or the harm which will come from breaking down recognized standards. In the inaintenance of local selfgovernment, on the one hand, and the national power, on the other, our country has been able to endure and prosper for near a century and a half. ${ }^{169}$

The question is how this passionate rhetoric of dual sovereignty can be reconciled with decisions like Stafford or the Wisconsin rate case. Two lines of explanation suggest themselves. The first emphasizes the form of congressional power, the second the substance.

1. Dual Sovereignty and the Form of Congressional Power. The first explanation is made visible by Bailey's companion case, Hill $v$. Wallace. ${ }^{170}$ Decided on the same day as Bailey, Hill struck down the Future Trading Act, ${ }^{171}$ which essentially used federal taxing power to impose a detailed regulatory scheme on boards of trade. Because "[t]he manifest purpose of the tax" was to "compel boards of trade to comply with regulations" of "a concern or business wholly within the police power of the State,"172 the Court concluded that, as in Bailey, the Act could "not be sustained as an exercise of the taxing power of Congress conferred by $\S 8$, Article I." ${ }^{, 73}$ The Court, in an opinion by

tention to their vital importance, as Chief Justice Taft has done upon the present occasion.

Id.

169. Child Labor Tax Case, 259 U.S. at 37.

170. 259 U.S. 44 (1922).

171. Pub. L. No. 67-66, 42 Stat. 187 (1921).

172. Hill, 259 U.S. at 66-67.

173. Id. at 68. In Trusler v. Crooks, 269 U.S. 475 (1926), the Court later struck down other provisions of the Future Trading Act on the same grounds as Hill. Id. at 482. 
Taft, also held that the Act could not be "sustained under the commerce clause of the Constitution"174 because there was "not a word in the act from which it can be gathered that it is confined in its operation to interstate commerce. ${ }^{\text {,175 }}$

The transactions upon which the tax is to be imposed... are sales made between members of the Board of Trade in the City of Chicago for future dehivery of grain, which will be settled by the process of offsetting purchases or by a delivery of warehouse receipts of graim stored in Chicago. Looked at in this aspect and without any limitation of the application of the tax to interstate commerce, or to that which the Congress may deem from evidence before it to be an obstruction to interstate commerce, we do not find it possible to sustain the validity of the regulations as they are set forth in this act. A reading of the act makes it quite clear that Congress sought to use the taxing power to give validity to the act. It did not have the exercise of its power under the commerce clause in mind and so did not introduce into the act the limitations which certainly would accompany and mark an exercise of the power under the latter clause. ${ }^{176}$

174. Hill, 259 U.S. at 68.

175. Id.

176. Id. at 68-69. Brandeis concurred separately to say that, while he agreed that the Act was unconstitutional, he doubted whether "plaintiffs are in a position to require the court to pass upon the constitutional question in this case." Id. at 72 (Brandeis, J., concurring). In the Brandeis papers, there is an early draft of this opinion which is cast as a dissent. Hill $v$. Wallace file, Brandeis Papers, supra note 116. We have extant virtually identical letters sent by Taft to Van Devanter and Brandeis, describing that he had reached in his opinion "a different conclusion from that which was voted at conference." Letter from William Howard Taft to Louis D. Brandeis (May 12, 1922), Taft Papers, supra note 104, Reel 241; Letter from William Howard Taft to Willis Van Devanter (May 12, 1922), Van Devanter Papers, supra note 116. To Brandeis, Taft wrote:

[W] voted first that there was equitable jurisdiction by a vote of 7 to 1 , you voting "No", and Justice Holmes being doubtful. On the question whether it could be sustained as a taxing act, the vote stood 7 to 1 , Justice McKenna casting the negative vote, and you not voting. Later we took a vote as to whether the act could be sustained as a regulation of interstate commerce. At first, by a vote of 5 to 4 , it was held that it could not be sustained. Later there was a change, and by a vote of 5 to 3 , you not voting, its validity as a regulation of interstate commerce was sustained. On a close examination of the case, the law and the record, I have reached the conclusion stated in this opinion, namely that we have jurisdiction, that the law is invalid as a taxing law, and that it can not be sustained as a valid regulation of interstate commerce.

Letter from Williaun Howard Taft to Louis D. Brandeis (May 12, 1922), Taft Papers, supra note 104, Reel 241. That same day Brandeis wrote back to Taft that:

Your argument that the law cannot be sustained either as a taxing act or as a regulation of interstate commerce is strong and convincing. I still feel grave doubt whether there is equity jurisdiction ... and am not yet certain what I ought to do. Probably I should concur \& state my doubt as to cause of action etc. 
This language rather broadly intimated that Congress could constitutionally reimpose the very regulations at issue in Hill if only they were properly justified as protections of interstate commerce. ${ }^{17}$ In less than three weeks Congress took the hint, and a bill was introduced in the House "for the prevention and removal of obstructions and burdens upon interstate commerce in grain by regulating transactions on grain future exchanges." ${ }^{\prime 178}$ By the end of the summer Congress had enacted the Grain Futures Act, ${ }^{179}$ which imposed rules "substantially identical" to those of the Future Trading Act, ${ }^{180}$ but which purported

Letter from Louis Brandeis to William Howard Taft (May 12, 1922), id. The question of whether Hill created a precedent for suits restraining the collection of taxes, in violation of 26 U.S.C. \& 7421, would cause embarrassment for the Court the following year in Grahom v. Du Pont, 262 U.S. 234, 257-58 (1923). We have a letter from Taft to Brandeis, discussing the difficulties he faced in drafting Graham in hight of the Court's decision in Hill:

Your suggestion that the tax in Hill vs. Wallace was in effect a penalty, because prohibitive and intended to stop, appeals to inc, and I shall try and add soinething to the opinion of that sort so as to reheve us from embarrassment in the future. In other words, I might add something like this:

Perhaps it would be better to mclude Hill vs. Wallace in the class of cases represented by Lipke vs. Lederer, [259 U.S. 557 (1922)], in that the tax imposed was really in the nature of a penalty to enforce a regulation than a tax in the proper sense.

Do you think that would be sufficient and give us a chance in the future to avoid the use of Hill vs. Wallace as an uncomfortable precedent?

Letter froin William Howard Taft to Louis D. Brandeis (May 18, 1923), Taft Papers, stupra note 104, Reel 253.

177. In fact the Court stated that because "sales for future delivery on the Board of Trade are not in and of themselves imterstate commerce," they

can not come within the regulatory power of Congress as such, unless they are regarded by Congress, from the evidence before it, as directly interfering with interstate commerce so as to be an obstruction or a burden thereon.... It was upon this principle that, in Stafford $v$. Wallace ... we held it to be withm the power of Congross to regulate business in the stockyards of the country, and include therein the regnlation of commission men and of traders there, although they had to do only with sales completed and ended within the yards, because Congress had concluded that through exorbitant charges, dishonest practices and collusion they were likely, unless regulated, to impose a direct burden on the interstate commerce passing through.

Hill, 259 U.S. at 69 . This language pointed rather directly to the intent and purpose of Congress as the measure of constitutional power.

178. 62 CONG. REC. 7987 (1922) (statement of Rep. Jasper Tincher upon introducing H.R. 11843).

179. Pub. L. No. $67-331$, ch. 369 , 42 Stat. 998 (1922).

180. Note, Two Attempts to Regulate the Grain Trade: Findings of Fact by Congress, 37 HARV. L. REV. 136, 138 (1923) "“Congress quickly grasped the inferential suggestion that a similar statute might be upheld if based on the cominerce clause, and passed the Grain Futures Act."); see also Grain Futures Act Is Upheld, L.A. TIMES, Apr. 17, 1923, at 22:

Promptly Congress met the issue by re-enacting substantially all the regulatory features of the law, but based its new exercise of authority on its control over interstate commerce, declaring that trading in grain futures, unless properly regulated by the Federal government, could be made a restraint upon interstate shipmonts of grain. 
to rest on Congress's commerce power. The Grain Futures Act was upheld in Board of Trade v. Olsen, ${ }^{181}$ in which Taft, writing for the Court, ${ }^{182}$ explained that the Act contained "the very features the absence of which we held in ... soinewhat carefully framed language... prevented our sustaining the Future Trading Act." ${ }^{\text {"s }}$ Taft stressed

181. 262 U.S. 1 (1923). McReynolds and Sutherland dissented without opinion. Butler's docket book indicates that at conference Holmes had voted to strike down the Act, while McKenna was uncertain about his view of the question. On the day of the decision, Taft wrote to his brother that:

I deliver an inportant opinion this morning sustaining the validity of an act of Congress putting the Chicago Grain Board under federal control and compelling them to admit ... representatives of cooperative farmers' associations on payment of regular dues and coinpliance with rules. I delivered a similar opinion in the matter of the Chicago Stockyards Act last year. I have carried the Court in both cases against considerable oppositiou not apparent in the vote.... If there ever was real interstate and foreign commerce it is that which is transacted on these two boards. It affects and dominates the consumers of the world in food products. It is just what our ancestors were seeking to lave Congress regulate. Whether the legislation will do any good is another question but it does this good that the farmers lave their oun secretary of agriculture to supervise these two markets which they have always denounced as the chief sources of their woe.

Letter from William Howard Taft to Horace D. Taft (Apr. 16, 1923), Taft Papers, supra note 104, Reel 252. On that same day, Taft wrote his son that

To-day I decide one of the most important cases that I have had to dispose of, and that is the constitutionality of the Chicago Board of Trade case. I decided the stock yards case last year, and now this comes up this year, and 1 think I have carved out a view of interstate commerce which is useful for the purpose of bringing within Congressional control the real centers of our interstate and forcign commerce. How valuable in results that control by Congress may be we can not guarantee-that is not our business-but we shall have put the power where in substance and real effect under the Constitution it ought to be.

Letter from William Howard Taft to Robert A. Taft (Apr. 16, 1923), id. The dccision was regarded by the press as "a nationally inportant case" that represented "a staggering victory" for "the farm bloc." The Supreme Court Fences the Pit, LITERARY DIG., May 5, 1923, at 16 (quoting the Norfolk Virginian-Pilot).

182. Taft first circulated his opinion privately to Van Devanter and to Brandeis. In the Van Devanter papers, there is a note from Taft stating: "I send this opinion in the Board of Trade case for your overhauling without mercy. I know that you are busy but you are 100 good natured for your own good.... I have not circulated it. I have sent it to Brandeis, J." Letter from William Howard Taft to Willis Van Devanter (Apr. 4, 1923), Van Devanter Papers, supra note 116.

183. Olsen, 262 U.S. at 32. Taft, as he had in Stafford, paid elaborate liomage to Holmes's opinion in Swift:

[Stafford] was but the necessary consequence of the conclusions reached in the case of Swift \& Co. v. United States, 196 U.S. 375. That case was a milestone in the interpretation of the commerce clause of the Constitution. It recognized the great changes and developnent in the business of this vast country and drew again the dividing line between interstate and intrastate commerce where the Constitution intended it to be. It refused to permit local incidents of great interstate movement, which taken alone were intrastate, to cliaracterize the movement as such. The Swift Case inerely fitted the commerce clause to the real and practical essence of modern business growth. It applies to the case before us just as it did in Stafford $v$. Wallace. 
that in the Grain Futures Act Congress purported "to regulate interstate commerce and sales of grain for future dehvery on boards of trade because it [found] that by manipulation they have become a constantly recurring burden and obstruction to that commerce."184

In the act we are considering, Congress has expressly declared that transactions and prices of grain in dealing in futures are susceptible to speculation, manipulation and control which are detrimental to the producer and consumer and persons handling grain in interstate commerce and render regulation imperative for the protection of such commerce and the national public interest therein.

It is clear fron the citations, in the statement of the case, of evidence before committees of investigation as to nranipulations of the futures market and their effect, that we would be unwarranted in rejecting the finding of Congress as unreasonable, and that in our inquiry as to the vahidity of this legislation we must accept the view that such nianipulation does work to the detriment of producers, consuners, shippers and legitinuate dealers in interstate commerce in grain and that it is a real abuse. ${ }^{185}$

Olsen upheld the very regulations Hill had struck down as invading the regulatory domain of the states. This strongly suggests that the Court in Hill was less concerned with reserving a distinct economic sphere for the exclusive regulation of the states than it was focused on the form of power exercised by Congress. An important theme in Bailey had been the notion that if national taxing authority became an unrestrained platform for regulation, there would be virtually no limit to federal power. ${ }^{186}$ The contrast between $\mathrm{Hill}$ and $\mathrm{Ol}$ -

Id. at 35. Actually, however, as in Stafford, the problem facing the Court in Olsen concerned the facial coustitutionahity of a rule, as distinct from the constitutionality of particular applications of a rule. Olsen was thus about quite different issues from those that concerned the Court in Swift, see supra notes 154-58 and accompanying text, and was therefore in spirit and rationale much closer to Railroad Commission v. Chicago, Burlington \& Quincy Railroad Co., 257 U.S. 563 (1922). It is possible, therefore, that Taft's focus on Swift was a deliberate effort to capturc Holnes's vote, which in conference had been against the Act's constitutionality. See supra note 181.

184. Olsen, 262 U.S. at 32.

185. Id. at 37-38.

186. See, e.g., 259 U.S. at 37-38:

Out of a proper respect for the acts of a co-ordinate branch of the Government, this court has gone far to sustain taxing acts as such, even though there has been ground for suspecting from the weight of the tax it was intended to destroy its subject. But, in the act before us, the presumption of vahidity cannot prevail, because the proof of the contrary is found on the very face of its provisions. Grant the vahdity of this law, and all that Congress would need to do, hereafter, in seeking to take over to its control 
sen indicates that the Court was determined to ensure that federal taxing authority did not becoine a blank check for federal legislation. ${ }^{187}$ That is why the very regulations struck down in Hill could be

any one of the great number of subjects of public interest, jurisdiction of which the States have never parted with, and which are reserved to them by the Tenth Amendment, would be to enact a detailed measure of complete regulation of the subject and enforce it by a so-called tax upon departures from it. To give such magic to the word "tax" would be to break down all constitutional limitation of the powers of Congress and completely wipe out the sovereignty of the States.

If the potentially limitless scope of the taxing power rendered it particularly susceptible to possible abuse, and hence in need of constitutionally restrictive interpretation, the more narrow scope of relatively specific grants of power, like the Eighteenth Amendment or the Spending Clause, rendered them correspondingly less dangerous to the principles of dual sovereignty. This may explain why the Court felt free to interpret them as gencrously authorizing congressional power.

187. Later in the decade, however, the Taft Court would begin to back off the severity of its holding in Bailey. At first it dropped dark hints about the constitutionality of Congress's use of its taxing power to regulate narcotics in the Harrison Act, Pub. L. No. 63-233, 38 Stat. 785 (1914). See, e.g., Umited States v. Dauglicrty, 269 U.S. 360, 362-63 (1926):

The constitutionality of the Anti-Narcotic Act, touching which this Court so sharply divided in United States y. Doremus, 249 U.S. 86, was not raised below and has not been again considered. The doctrine approved in Hammer v. Dagenhart, 247 U.S. 251; Child Labor Tax Case, 259 U.S. 20; Hill v. Wallace, 259 U.S. 44, 67; and Linder v. United States, 268 U.S. 5, may necessitate a revicw of that question if hereafter properly presented.

Linder v. United States, 268 U.S. 5,17 (1925):

Congress cannot, under the pretext of executing delegated power, pass laws for the accomplishment of objects not entrusted to the Federal Government. And we accept as established doctrine that any provision of an act of Congress ostensibly enacted under power granted by the Constitution, not naturally and reasonably adapted to the effective exercise of such power, but solely to the achievement of something plainly within power reserved to the states, is invalid and cannot be cnforced.

When actually faced with the issue, however, the Court, in a 6-3 decision authored by Taft, upheld the Harrison Act as a proper revenue mcasure. Nigro v. United States, 276 U.S. 332, 334 (1928); see also Alston v. United States, 274 U.S. 289, 294 (1927) (holding that the first section of the Harrison Act was a valid exercise of the taxation power). When Federal District Judge George M. Bourquin accused "a couple of Supreme Court judges" of getting "cold feet" when the Court deelined to declare the Harrison Act unconstitutional, Federal Judge Again Scores Narcotic Law, S.F. CHRONICLE, Oct. 6, 1928, at 3, Taft dashed off a note to Van Devanter. "Bourquim seems to be something of an ass." Letter from William Howard Taft to Willis Van Devanter (Oct. 22, 1928), Taft Papers, supra note 104, Reel 305. Van Devanter added, "I concur." Id. It is probable that although Brandeis joined the Court's decision in Nigro, he disapproved of the policy of the Act:

Charles Warren, who is much concerned by drugs (He had the narcotic cases under him while in the Dept.), thinks the Act has been practically futile; and that conditions have grown infinitely worse since. Cannot someone be found who will really enquire into the results of the Federal police legislation (othcr than liquor) \& exhibit the balance sheet? I am disposed to think that it does grave harm to a great degree otherwise than in centralization. i.a. in misleading the community into the belief that the fed. Govt (or any government) can lielp, imstead of turning folk back to themselves for the remedy in self-mastery.

BRANDEIS-FRANKFURTER LETTERS, supra note 148, at 198-99. 
upheld when they were reconceptualized as an exercise of the cominerce power, which was intrinsically narrower and more restrictive than the power to tax.

Olsen displayed the same appreciation of the integrated nature of the national inarket as did Stafford. It required that Congress justify its regulations as efforts to protect that market, and it was willing to grant substantial deference to Congress on this question. ${ }^{188}$ The Court was willing to cede Congress ample room to protect an interstate commerce that it imagined as a "great interstate movement," "current" that "flows... from the West to the East, and from one State to another," the nation. ${ }^{191}$ But the contrast between Hill and Olsen also suggests that the Court was concerned about the form of congressional legislation, so as to ensure that the attention of federal lawmakers was properly focused on the actual requirements of interstate cominerce. $^{192}$

\section{Dual Sovereignty and the Substance of Congressional Legis-} lation. Concerns about the form of congressional legislation, however,

188. In the last years of his life Taft stressed "the all-inclusiveness of the regulation of intcrstate commerce entrusted to Congress." Letter from William Howard Taft to Harlan Fiske Stone (Aug. 31, 1928), Taft Papers, supra note 104, Reel 304.

In Gibbons v. Ogden, and in other cases following it, the breadth and scope of the Congressional power can hardly be made greater. The power of Congress in this respect is described as exactly what it would be in a government without states, and to include all that the legislature of such a government could do in regulating coinuncrce and navigation, except a violation of the Fifth Amendment.

Id. This interpretation of federal commerce power, however, is incoinpatible with Taft's consistent support for the Court's decision in Hammer v. Dagenhart. See supra note 164. In the 1920s, Hammer stood for the proposition that the Court could examine the purposes of congrcssional regulation of interstate commerce to determine whether they were pretextual; i.c., whether Congress had tried to achieve ends not otherwise within its authority. See supra note 187 . Such scrutiny of congressional purpose is flatly inconsistent with conceptualizing congressional cominerce power as the equivalent of plenary state pohice power, limited only by the subject matter of "commerce and navigation."

189. Olsen, 262 U.S. at 35.

190. Stafford v. Wallace, 258 U.S. 495, 516 (1922).

191. For an example of popular linkage of federal power over railroads and federal power over integrated aspects of national economic life, like grain, see Editorial, Overlapping Regullt. tions, N.Y. TIMES, June 12, 1922, at 14; see also SARAH H. GORDON, PASSAGE TO UNION: HOW THE RAILROADS TRANSFORMED AMERICAN LIFE, 1829-1929, at 347-48 (1996) ("By 1900 tho social order that had einerged in the U1rited States was overwhelmingly based on the principle of national commercial exchange.... [T] he railroads held a promment position in defining the social order, a position threatened ouly by the introduction of an even better systein of transportation.").

192. See supra note 177 and accompanying text. 
cannot offer an adequate explanation of Bailey. This is because the Court in Hammer v. Dagenhart had already struck down Congress's efforts to reach child labor by focusing on the form of interstate commerce. ${ }^{193}$ In the specific context of Bailey, therefore, the Court's effort to maintain the structural constraints of dual sovereignty inust also be understood as reflecting substantive disapproval of congressional atteinpts to regulate relationships of einployment, ${ }^{194}$ regardless of whether Congress intended such regulation to protect an integrated national market. ${ }^{195}$

Bailey and Dagenhart reproduce the traditional distinction between commerce and manufacturing that the Taft Court had inherited from its predecessors and that it continued carefully to uphold in the context of federal antitrust law. ${ }^{196}$ The question is why the Taft Court so forcefully sought to maintain this distinction in the context of child labor regulation, when it was unravehing analogous distinctions in the context of railroad rates, stockyards, and boards of trade. If the Court in Stafford or Olsen could acknowledge the systematic interdependence of local and national transactions, why not also in Bailey? The explanation lies in the confluence of two factors. The first concerns the perspective on federal power that was pervasive during the Taft Court era; the second concerns the specific kinds of rights that were at issue in Bailey.

It was common in the years preceding the New Deal to conceptualize federalism as a problem of "reconciling centralization with self-government." The "bureaucratic hypertrophy"198 of a "re-

193. See supra note 164 and accompanying text.

194. Writing after Carter v. Carter Coal Co., 298 U.S. 238 (1936), which most explicitly exemplified this disapproval, Edward Corwin observed that

just as the primary purpose before the Civil War of the doctrine of powers exclusively' reserved to the States was the protection of the relationship between master and slave from interference by the National Goverament, so its primary purpose nowadays is to protect similarly the relationship of employer and cmployee, except in the case of interstate carriers.

CORWIN, supra note 43, at 208-09.

195. Federal regulation of child labor was defended precisely on the ground that

The country has become an economic unit; production in one state is intimately affected by costs and conditions of production in another state. The country is becoming increasingly a social and political unit. Its citizens every where in the urion must suffer from a continuing injury to its citizens in any part of the union.

Medill McCormick, Child Labor Must Go, 29 AM. FEDERATIONIST 644, 644 (1922).

196. See supra notes $100-03$ and accompanying text.

197. Briggs, supra note 29 , at 311 .

198. Bruce, supra note 124 , at 644 . 
mote ... government"199 was typically contrasted to "the true ideals of liberty and Democracy" exemplified in the "local self-government" of the states. ${ }^{200}$ The very scope and diversity of the country was said to imply "that no one central authority can supervise the daily lives of a hundred million people, scattered over half a continent, without becoming top-heavy" with "the burden of federal bureaucracy." was accordingly great apprehension of Congress's potential to evolve into "a centralized governmental machine." ${ }^{202}$ Henry Wade Rogers, dean of the Yale Law School, well summarized this perspective when he inveighed agamst federal centralization in the pages of the North American Review:

The writers on political institutions have pointed out many times the advantages of local government over centralized government. They have taught us that local self-government develops an energetic citizenship, and centralization an enervated one; ... that under local self-government officials exist for the benefit of the people, and that under centralization the people exist for the benefit of the officials; that local self-government provides for the political education of the people, and that centralization, based upon the principle that everything is to be done for the people rather than by the people, creates a spirit of dependence which dwarfs the intellectual and moral faculties and incapacitates for citizenship;... that under local self-government every individual has a part to perform and a duty to discharge in public affairs, while under a centralized government one's affairs are managed by others. ${ }^{203}$

199. Warren, supra note 35, at 377 .

200. Albert C. Ritchie, Give Us Democracy: A Plea for Freedom from Federal Transgression in the Domain of the State, 230 N. AM. REV. 400, 400, 402 (1930). Even so shrewd an observer as Woodrow Wilson could advance this hine of analysis, as when he argued

that centralization is not vitalization. Moralization is by hife, not by statute; by the interior impulse and experience of communities, not by fostering legislation which is merely the abstraction of an experience which may belong to a nation as a whole or to many parts of it without having yet touched the thought of the rest anywhere to the quick.

WILSON, supra note 3, at 197. "Deliberate adding to the powers of the federal government by sheer judicial authority," Wilson concluded, would "certainly mean ... by degrees to do away with our boasted systein of self-government." Id. at 195-96. For an analogous inodern affirmation of the value of local self-government, see Barry Friedman, Valuing Federalism, 82 MINN. L. REV. 317, 389-97 (1997).

201. PIERSON, supra note 40, at 144; see also Anti-Federalism, supra note 31, at 212 (discussing the perceived negative effects of an expanding federal government).

202. Franklin, supra note 168, at 508.

203. Henry Wade Rogers, The Constitution and the New Federalism, 188 N. AM. REV. 321, 334-35 (1908) (emphasis added). Of course progressives who viewed as "absurd" those who 
Taft's opinion in Bailey gestures toward this account of federalism when it contrasts "national power" to "the maintenance of local self government. ${ }^{\text {,204 }}$

It followed from this understanding of federalism that congressional statutes were intrinsically more dangerous than state legislation. Even if the substance of federal and state regulation was otherwise identical, the former constituted a more powerful threat to constitutional values than the latter. Whereas state law was seen as exemplifying the value of self-government, federal control was regarded as inclined to slide toward the oppression of an alien and distant bureaucracy. This distinction was of particular importance when Congress sought to regulate forms of behavior the Taft Court understood as of great constitutional significance.

professed "to see the approaching extinction of the American democracy in what they call the drift toward centralization," argued that "a measure of Federal centralization" merely bestowed "on the Federal government powers necessary to the fulfillment of its legitimate responsibilities," in the exercise of which the national government served as an authentic instrument of popular will. HERBERT CROLY, THE PROMISE OF AMERICAN LIFE 277-79 (The Bclknap Press of Harvard Press 1965) (1909). Taking aim at "[t]he majority of Americans" who "still shrink from removing the legal obstacles to the organization of an all-powerful national government, because they have no confidence in the ability of popular opinion to cmploy discreetly or to control sufficiently such a formidable engine of poitical authority," progressives issued a powerful challenge:

A nation without sufficient self-confidence to organize and operate a government capable of being flexibly adapted to the serious practical emergencies of its own carecr, is trying to dispense with the spiritual foundation of all thoroughgoing democracy.... And as a consequence of proving false to the spirit of democracy ... its legal machinery will break down unless it is moulded and informed by the democratic principle of ultimate popular control of all the machinery and instruments of government.

Government According to Law, NEW REPUBLIC, Nov. 6, 1915, at 4, 4, 5 .

204. 259 U.S. at 37. It is noteworthy, moreover, that the opinion describes the child labor tax law as "a penalty to coerce people of a State to act as Congress wishes them to act in respect of a matter completely the business of the state government under the Federal Constitution." Id. at 39 (emphasis added). For an example of Taft explicitly appealing to this account of the potentially oppressive and managerial nature of federal power, sec Taft, Federal Power, supra note 109 , at 78 ("No one who has been familiar with the working of the conservation system in the West can be unacquainted with the difficulty that has arisen from Washington management of matters that are really of a local nature."); id. at 77 (Prohibition would require a "perfect army" of federal officials ... to carry out such a law in the states a majority of whose people do not approve it. This horde of federal employees, policemen, and deteetives, will be managed directly from Washington."); id. at 78 (quoted in supra note 109). In 1912, as president, Taft had argued that whereas "the Federal Government touches the citizen only at intervals," the

State and is municipal divisions are with him always, and the opportunity for improving general conditions by limitations of a police and hygiemic cliaracter and the betterment and proper control of all the public utilities which go to serve general and individual comfort, are all within the proper office of the State legislature.

Address of President Taft to the General Court of the Legislature of Massachusetts, Mareh 18, 1912, Taft Papers, supra note 104, Reel 569. For a discussion of Taft's various vicws on federalism, see generally Post, supra note 164. 
It has been shrewdly and accurately observed that the Court's expansive support for federal commerce power articulated in the railroad cases, and in decisions like Stafford and Olsen, was advanced within the context of statutes that regulated what in the 1920s was called property "affected with a public interest." erty affected with a pubhic interest included the rates of public utilities and of railroads. In the 1920s, property affected with a public interest was sharply contrasted to ordinary property, because the former, unlike the latter, could be subject to "intimate public regulation"206 without raising due process concerns under the Fiftl or Fourteenth Amendments. Whereas ordinary property received strict constitutional protection "on the supposition that individual liberty and selfdetermination could not exist without scrupulous respect for titles to property and a free hand for individuals in acquiring it and using it,"207 property affected with a public interest had lost this presumptive iminunity from state regulation ${ }^{208}$ precisely because it was conceived as so implicated in forms of systemic interdependence as to have lost unuch of its constitutional value. ${ }^{209}$ Property affected with a public interest was so subject to government management that it could no longer function as a significant vehicle for either "individual liberty" or "self-determmation.",110

205. See BARRY CUSHMAN, RETHINKING THE NEW DEAL COURT: THE STRUCTURE OF A CONSTITUTIONAL REVOLUTION 141-53 (1998) [hereinafter CUSHMAN, RETHINKING] (discussing the evolution of the Commerce Clause doctrine); Barry Cushman, Formallsm and Realism in Commerce Clause Jurisprudence, 67 U. CHI. L. REV. 1089, 1128-29 (2000) [hereinafter Cushman, Formalism] (describing the interplay on the New Deal Court between Commerce Clause jurisprudence and due process limitations on the federal government). On the Taft Court's jurisprudence of property affected with a public interest, see Post, supra note 10, at 1505-29.

206. Chas. Wolff Packing Co. v. Court of Indus. Relations, 262 U.S. 522,539 (1923).

207. Anti-Federalism, supra note 31 , at 213.

208. On the presumptive immunity of ordinary property, see infra note 299 and accompanying text.

209. I do not mean to imply, however, that property affected with a public interest was entirely without constitutional significance. See, e.g., United Rys. \& Elec. Co. v. West, 280 U.S. 234, 249 (1930):

[T] he fundamental principle to be observed is that the property of a public utility, although devoted to the public service and impressed with a public interest, is still private property; and neither the corpus of that property nor the use thereof constitutionally can be taken for a compulsory price which falls below the measure of just compensation.

The point is rather that property affected with a public interest was so "impressed with a public interest," and hence so detached from individual autonomy, that it could be routinely regulated by the government in ways that ordinary property could not.

210. For a discussion, see Post, supra note 10, at 1529-45. 
National regulation of ordinary property was for this reason more likely to trigger concerns about oppressive federal poiver than was national regulation of property affected with a public interest. Far more fundamental constitutional values were at stake in the control of the former than of the latter. In understanding Bailey, therefore, it is necessary to recall that the Taft Court understood "freedoin in the inaking of contracts of personal employment, by which labor and other services are exchanged for money or otlier forms of property" to be "an elementary part of the rights of personal liberty and private property, not to be struck down directly or arbitrarily interfered with." ${ }^{211}$

The child labor tax statute stuck down in Bailey regulated precisely such ordinary contracts of personal employment. Although the Court had held im 1913 that prohibitions of child labor did not violate the Fourteenth Amendinent, ${ }^{212}$ such prohibitions nevertheless implicated the same issues of individual liberty as those raised by any government restrictions of ordinary property or contracts of einployment. The child labor tax statute was in this respect analogous to other federal statutes that used federal Commerce Clause power to regulate everyday commercial transactions in ways that were not prohibited by the Due Process Clause.

Because federal regulations of such transactions posed distinct dangers of bureaucratic oppression not present in otherwise identical state regulations, the Taft Court typically sought carefully to cabin congressional restrictions on ordinary commercial transactions by appealing to principles of federalism. Without particular controversy or fanfare, the Court scrupulously policed the constitutional scope of federal jurisdiction im the application of the Sherman Antitrust Act, ${ }^{213}$

211. Prudential Ins. Co. v. Cheek, 259 U.S. 530, 536 (1922).

212. Sturges \& Burn Mfg. Co. v. Beauchamp, 231 U.S. 320, 325-26 (1913).

213. Ch. 647, 26 Stat. 209 (1890); see, e.g., Ramsay Co. v. Associated Billposters, 260 U.S. 501, 511 (1923) (distinguishing between business practices that "directly affect[ local business only" and "those designed and probably adequate materially to interfere with the free flow of commerce among the States and with Canada"); Fed. Baseball Club v. Nat"l League of Pror! Baseball Clubs, 259 U.S. 200, 208 (1922) (holding that, although players travel to different states for games, professional baseball is not interstate commerce because exhibitions of baseball are "purely state affairs"); supra notes 95-104 and accompanying text. In Moore v. New York Corton Exchange, 270 U.S. 593 (1926), the Court refused to apply federal antitrust laws to a commodities exchange, declaring that

The New York exchange is engaged in a local business. Transactions between its members are purely local in their inception and in their exccution.... If interstate shipments are actually made, it is not because of any contractual obligation to that ef- 
the Federal Employers' Liability Act, ${ }^{214}$ or the Federal Trade Commission Act. ${ }^{215}$ In such cases, the Court was concerned to enforce the logic of dual sovereignty in ways that are notably absent from decisions like Stafford or Olsen. Evidently federal laws potentially impinging upon the individual autonomy inherent in ordinary commercial transactions or contracts of employment aroused the Court's anxiety in ways that federal regulations of property affected with a public interest did not.

It is clear, noreover, that when the Taft Court confronted federal legislation unambiguously aimed at sustaining, rather than regulating, ordinary property, it was not tempted to deploy a vision of dual sovereignty to limit federal authority, even if congressional legislation was doctrinally indistinguishable fronı the Keating-Owen Child Labor Law invalidated in Dagenhart. In 1925, for example, the Court in Brooks v. United States ${ }^{216}$ unanimously upheld the National

fect... The most that can be said is that the agreements are likely to give rise to interstate shipments. This is not enough.

Id. at 604; see United States v. N.Y. Coffee \& Sugar Exch., 263 U.S. 611, 621 (1924) (holding that the Court, unlike Congress, cannot legislatively determine that intrastate transactions could systematically burden interstate commerce and hence become properly subject to federal jurisdiction).

214. Pub. L. No. 60-100, 35 Stat. 65 (1908); see, e.g., Balt. \& Ohio Southwestern R.R. Co. v. Burtch, 263 U.S. 540, 543 (1924) (holding that there must be incontrovertible evidence of interstate shipment before the Federal Employers' Liability Act would apply); Indus. Accident Comm'n v. Davis, 259 U.S. 182, 187-88 (1922) (holdimg that an employee who was injured while making a repair on an interstate train was not covered by the Federal Employers' Liability Act because the train was stationary at the time of the accident); Shanks v. Del., Lackawanna \& W. R.R. Co., 239 U.S. 556, 557 (1916) (same); The Second Employers' Liabihity Cases, 223 U.S. 1, 48-49 (1912):

Congress, in the exertion of its power over interstate commerce, may regulate the relations of common carriers by railroad and their employés, while both are engaged in such commerce, subject always to the limitations prescribed in the Constitution, and to the qualification that the particulars in which those relations are regulated must have a real or substantial connection with the interstate commerce in which the carriers and their employés are engaged.

Cf. The Employers' Liability Cases, 207 U.S. 463, 504 (1908) (holding the original Employer's Liability Act unconstitutional as beyond federal power). Although the Federal Employers' Liability Act sought to regulate railways, it regulated an aspect of the railroad business that was not ordinarily considered property affected with a public interest-namely, the employment relationship.

215. Pub. L. No. 63-203, 38 Stat. 717 (1914); see, e.g., FTC v. Pac. States Paper Trade Ass'n, 273 U.S. 52, 66 (1927) ("[A]s the contracts between the wholesaler and the retailer constitute a part of commerce among the States, the elimination of competition as to price by the application of the uniform prices fixed by the local association was properly forbidden by the order of the commission.").

216. 267 U.S. 432 (1925). 
Motor Vehicle Theft Act (NMVTA), ${ }^{217}$ which prohibited the knowing transportation in interstate commerce of stolen cars. Taft, who wrote the opinion, was a strong supporter of Dagenhart. ${ }^{218}$ Yet when in Brooks he sought to distinguish Dagenhart, the best he could do was to argue that the Keating-Owen Child Labor Law was "a congressional attempt to regulate labor in the State of origin, by an embargo on its external trade," banning from interstate commerce goods that "were harmless, and could be properly transported without injuring any person who either bought or used them."219 But a similar characterization could be apphed to the NMVTA, which was a congressional effort to regulate theft in the state of origim by banning from interstate commerce vehicles that were harmless in themselves.

What really seems to have distinguished Brooks from Dagenhart is that the latter concerned legislation regulating an ordinary contract of employment, whereas the fonner involved legislation unambiguously seeking to protect "the property rights of those whose machines against their will are taken into other jurisdictions." 2020 The NMVTA, as distinct froin the Keating-Owen Child Labor Law, was an effort to use national power to combat what all regarded as an "immorality" endangering ordinary property. Even though it was a federal effort to regulate local crime, which was ordinarily conceived as within the distinct police power of the states, the NMVTA did not trigger the Court's instinct to preserve an exclusive sphere of state sovereignty. ${ }^{22}$

217. Pub. L. No. 66-70, 41 Stat. 324 (1919).

218. See supra note 164.

219. Brooks, 267 U.S. at 438.

220. Id at 439; see Post, supra note 164, at 220 (discussing Chief Justice Taft's distinction between Congress's authority to regulate stolen cars in interstate commerce and its inability to regulate child labor).

221. Brooks, 267 U.S. at 436-37.

222. Indeed, the Court announced:

Congress can certainly regulate interstate commerce to the extent of forbidding and punishing the use of such commerce as an agency to promote immorality, dishonesty or the spread of any evil or harm to the people of other States froun the State of origin. In doing this it is unerely exercising the police power, for the benefit of the public, within the field of interstate commerce.

Id. The NMVTA, however, was not ineant to prevent "the spread of any evil or harm to the people of other States from the State of origin," but instead, like Dagenlian, to prevent harms within the state of origin. Id. at 436. And, of course, the child labor regulations at issue in Dagenhart were certainly an exercise of "the police power, for the benefit of the public, within the field of interstate commerce." Id at 436-37. The gross inaccuracy of Taft's characterizations are telling, because they graphically illustrate the Court's difficulty in distinguishing Dagenhart in a manner that did not turn on the substantive rights affected by the regulations at issue. 
Although Brooks did not cite cases like Stafford or Olsen for support, it did self-consciously align itself with a well-developed line of precedents upholding "the authority of Congress to keep the channels of interstate commerce free from immoral and injurious uses., ${ }^{, 23}$ These precedents took pains to stress that such federal regulation could only extend to "illicit articles" 224 that were not included in "the liberty protected by the Constitution,"225 for "surely it will not be said to be a part of anyone's liberty, as recognized by the supreme law of the land, that he shall be allowed to introduce into commerce among the States an element that will be confessedly injurious to the public morals."226 Thus, if Stafford and Olsen could uphold congressional authority in part because constitutional values associated with liberty of contract were not implicated by the regulation of property affected with a public interest, so the cases cited by Brooks explicitly stood for the proposition that these values were also not implicated by the regulation of confessedly immoral conduct, like theft.

\section{Dual Sovereignty and the Role of the Court}

There is, lowever, an important distinction between the precedents cited by Brooks and decisions like Stafford or Olsen. In upholding the Transportation Act of 1920, or federal regulations of stockyards or boards of grain, the Taft Court portrayed Congress as empowered to speak for a specifically national interest, the protection of interstate commerce. But in the precedents cited by Brooks, the Court imagined Congress as instead speaking for common values that

223. Caminetti v. United States, 242 U.S. 470, 491 (1917); see also Brooks, 267 U.S. at 437 (listing cases in which the Court upheld interstate regulations that prohibited various types of immorality).

224. Hipolite Egg Co. v. United States, 220 U.S. 45, 57 (1911).

225. The Lottery Case, 188 U.S. 321, 356 (1903).

226. Id. at 357. Taft explained the theoretical connection between immorality and the rights protected by substantive due process in the following way:

Reasonable restraint of personal liberty of action for the coinmon welfare is rcally a matter of degree. It is to be settled by the general and dominant opinion of all the people in a community of common purpose, common ideals and the common enjoyment of the blessings of liberty and justice. This crystallizes into a kind of moral code based on the vicious effect of practices sufficiently serious to affect the welfare of the community.

Our courts recognize this crystallization of public sentiment. When it is manifested in constitutional amendment and statute, they enforce it as part of the law of the land. They loold that it is not a forbidden restriction of personal liberty, but it is only the curtailment of complete freedoin of action that is necessary in the interest of society.

Taft, Prohibition, supra note 109, at 78. 
were shared by both federal and state governments. Thus, in Hoke \& Economides $v$. United States, ${ }^{27}$ which upheld the White-Slave Traffic Act ${ }^{23}$ that prohibited the transportation of women across state lines for "immoral purposes,"

Our dual form of government has its perplexities, State and Nation having different spheres of jurisdiction... but it must be kept in mind that we are one people; and the powers reserved to the States and those conferred on the Nation are adapted to be exercised, whether independently or concurrently, to proinote the general welfare, inaterial and moral. ${ }^{230}$

This image of an overarching unity, spanning state and federal governments, ultimately functioned to underwrite judicial support for federal legislation that imght otherwise be thought to efface the boundary between state and federal power.

It is striking that in neither Bailey nor Dagenhart does the Court imagine Congress as speaking for "one people" sharing a common "welfare, material and moral." The issue of child labor was no doubt a poor context in which to portray Congress as speaking for "one people," because the issue was so manifestly controversial. In fact, the Keating-Owen Child Labor Law was defended in Dagenhart precisely on the ground that it prevented "unfair competition" from states that did not themselves prohibit child labor..$^{231}$ Although progressives struggled to meet this difficulty by characterizing Congress as transcending local interests and authentically expressing a democratic will that was distinctly national, ${ }^{232}$ the Taft Court refused to equate the national voice of popular sovereignty with the articulation of "public morals."

The question, therefore, is the nature of the Court's authority im articulating the "public morals" that circumscribed congressional enactments. Although both Congress and the Court were equally anns

227. 227 U.S. 308 (1913).

228. Pub. L. No. 61-277, 36 Stat. 825 (1910).

229. The title of the Act was "An Act To further regulate interstate and foreign commeree by prohibiting the transportation therein for immoral purposes of women and girls, and for other purposes." Id.

230. Hoke \& Economides, 227 U.S. at 322.

231. Hammer v. Dagenhart, 247 U.S. 251, 273 (1918).

232. See supra note 203. 
of the national government, the Court distinguished its own authority from that of Congress. The Court was suspicious of Congress's potential to endanger "the ark of our covenant"233 by overflowing the boundaries of its limited powers and becoming, in the words of Harlan Stone, "a political organization not unlike that of the Roman Empire" that was "truly imperial in character." ${ }^{\text {"23 }}$ But the Court

233. The Child Labor Tax Case, 259 U.S. 20, 37 (1922).

234. In 1924, as attorney general under President Coolidge, Stone attacked presidential candidate Robert La Follette's proposed constitutional amendment allowing Congress to override Supreme Court decisions striking down federal legislation as unconstitutional. See supra note 167 and accompanying text; infra note 298 . The very first argument Stone advanced was that the La Follette amendment would undermine the values of federalism:

"When, therefore, we provide by constitutional amendmont that Congress may enact a law which the Supreme Court has declared to be unconstitutional ... we are lodging in Congress the power and authority to wipe out every vestige of State sovereignty and all the reserved powers of the States. With that provision in force, we would cease to be a national federation of States with sovereign powers vested in the Federal Government for purposes of conducting foreign relations, and those internal and external relations which pertain to a central, natural [sic] government. We would have created a political organization not unlike that of the Roman Empire where the Central Government, at first republican and later imperial in form, drew to itsclf the actual regulation and control, in minutest detail of every function of local government within the empire and its dependencies. It was this concentration of power in Rome over a vast territory differing widely in its local habits, customs and economic interests which prepared the way for the ultimate breakdown of the Roman governmental and administrative system and led to the ultimate separation of the empire into independent territorial sovereignties, whose Governments were better adapted to their local, economic and political needs than a Central Government at Rome could ever have been. It is hardly conceivable that the voters in the several States of the United States would ever take a step which would so completely renounce the rights of citizenship in the States and so wholly subject the States to domination of Congress, truly imperial in character."

William H. Crawford, La Follette Plan Called a Menace: Harlan Fiske Stone Says Attacks Are on the Constitution, Not the Supreme Court, N.Y. TIMES, Oct. 2, 1924, at A4 (quoting Stone). Stone argued that witliout the Court's jurisdiction to decide constitutional questions of federalism, it

"would prove to be practically impossible ... to establish a stable dual form of government, State and national. Every time that a State encroaches upon Congress, or Congress encroaches upon the State, the Supreme Court has power to deterinine where the right of the matter lies. In fact, the Supreme Court was the first real example in history, so far as I am aware, of the establishment of a judicial body to deter-" mine legal or constitutional rights as between independent sovereignties where they come into conflict."

Id. A few days later, Stone sent the New York Times article to Taft, commenting that "[t]he enclosed was given out on the spur of the moment and there was no opportunity for proof read. ing." Letter from Harlan Fiske Stone to William Howard Taft (Oct. 7, 1924). Taft Papers, supra note 104, Reel 268. The following month Claarles Evans Hughes made a similar attack on La Follette's proposed amendment, arguing that

"the essential local authority of the States, the very existence of State government depends upon the maintenance of the provisions of the Constitution. ... If one docs not wish a Government with constitutional limitations; if one does not wish to maintam the States with their local autonomy and thus obviate an over-centralized Gov- 
trusted its own competence to differentiate congressional enactments that authentically expressed common values from those that violated the logic of dual sovereignty by unduly expanding specifically national interests. Thus the Court was prepared to allow Congress to close interstate commerce to stolen cars or "outlaws of commerce" like adulterated food, ${ }^{235}$ but not to the products of child labor. It was prepared to permit Congress to deploy its taxing power to regulate the use of narcotic drugs, ${ }^{236}$ but not to forbid the use of child labor.

At stake in these distinctions was the contrast between specifically national imterests and interests deemed constitutionally to be shared by both federal and state governments. The Court reserved for itself the authority to discern these deeper and more universal interests. The Court thereby assigned to itself an authority that seemed weirdly to transcend the logic of dual sovereignty, because it collapsed the distinction between state and national spheres of power.

By refusing to defer to Congress's judgment concerning national priorities, the Court conceived itself as vindicating its role as a constitutional court protecting the values of federalism. What is hard for us to grasp, however, is that the Court apparently conceptualized this role as imphicating a form of authority that was more fundamental than the representation of merely national interests, for which Congress also purported to speak. Today we understand constitutional interpretation as an exphication of specifically national values. But when the Taft Court interpreted the Constitution in light of the "public morals" of the country, it was summoning not merely its role as a national constitutional court, but also its status as a common law tribunal. As we shall see in Part IV, the Court refused to assign the common law to either state or national spheres of sovereignty, and it understood the function of the common law to be that of identifying and conserving traditional mores. The common law was believed to distill all the fundamental values of the American people, and not merely the discrete values associated with the distinct enterprise of nationhood. Although today we sharply distinguish between constitutional and common law courts, in the 1920s these two forms of

ermment which would increase our political difficultics a thousandfold... then he should follow Senator La Follette."

Hughes Here Sees Coolidge Victory; Assails His Foes, N.Y. TMME, Nov. 2, 1924, at A17 (quoting Hughes).

235. Hipolite Egg Co. v. United States, 220 U.S. 45, 58 (1911).

236. See supra note 187. 
judicial power were conceptually and jurisprudentially interconnected. Each contributed to the Taft Court's construction of American federalism.

\section{FEDERALISM AND NATIONAL JUdiCial POWER}

Contemporary constitutional theory differentiates questions of structure from questions of individual rights. ${ }^{237}$ Cases like Dagenhart, Bailey, Stafford, and Brooks, however, suggest that the pre-New Deal Court connected issues of congressional power to issues of individual rights im complex and subtle ways. Just as due process concepts like "public morals" or "property affected with a public interest" importantly influenced the structural limitations which the Court was prepared to inpose upon congressional power, so the Taft Court selfconsciously defined and created individual rights precisely in order to protect and sustain the integration of the national market. The Court pursued this policy not only in its role as a federal constitutional tribunal, but also in its role as a traditional common law court. The Taft Court in fact fused these two distinct forms of judicial authority to becoine itself a uniquely significant factor in the distribution of power between the nation and the states.

\section{A. National Judicial Power, Structure, and Individual Constitutional Rights}

Ever since its inception, the doctrime of substantive due process had been exphicitly deployed by the Court to protect the structural integrity of the national market. Allgeyer v. Louisiana, ${ }^{228}$ which is sometimes said to have initiated the doctrime, actually concerns a Louisiana statute that forbade Louisiana citizens from entering into contracts of insurance outside the state with foreign insurance companies that had not complied with Louisiana laws. ${ }^{239}$ Although All-

237. See, e.g., JesSE H. CHOPER, JUdicial Review AND THE NA'TIONAL POLITICAL PROCESS: A FUNCTIONAL CONSIDERATION OF THE ROLE OF THE SUPREME COURT 1-2 (1980) (distinguishing between constitutional questions of rights and constitutional questions of structure). I do not mean to imply, of course, that the structural decisions of the contemporary Court are somehow uninfluenced by its views of individual rights. For a discussion of such influence, see generally Robert C. Post \& Reva B. Siegel, Equal Protection by Law: Federal Antidiscrimination Legislation After Morrison and Kimel, 110 YALE L.J. 441 (2000).

238. 165 U.S. 578 (1897).

239. "We have then a contract which it is conceded was made outside and beyond the limits of the jurisdiction of the State of Louisiana, being made and to be performed within the State of New York, where the premiums were to be paid and losses, if any, adjusted." Id. at 588. 
geyer speaks generally about the "hiberty" protected by the Due Process Clause of the Fourteenth Amendment, ${ }^{2+0}$ it also specifically upholds the right of Louisiana to prohibit such contracts if they are made within the state. ${ }^{241}$

In the privilege of pursuing an ordinary calling or trade and of acquiring, holding and selling property must be embraced the right to inake all proper contracts in relation thereto, and although it may be conceded that this right to contract in relation to persons or property or to do business within the jurisdiction of the State may be regulated and sometimes prohibited when the contracts or business conflict with the pohicy of the State as contained in its statutes, yet the power does not and cannot extend to prohibiting a citizen from inaking contracts of the nature involved in this case outside of the limits and jurisdiction of the State, and which are also to be performed outside of such jurisdiction; nor can the State legally prohibit its citizens from doing such an act as writing this letter of notification, even though the property which is the subject of the insurance may at the time when such insurance attaches be within the limits of the State. The mere fact that a citizen may be within the limits of a particular State does not prevent his making a contract outside its limits while he himself remains within it. $^{242}$

The actual holding of Allgeyer, then, is that a state can regulate insurance contracts made and performed within its jurisdiction, but not those made and performed outside its jurisdiction. The underlying pohicy of the case is thus focused less on the abstract protection of liberty of contract, than on protecting the access of citizens to the na-

240. Id. at 589:

The liberty mentioned in that amendment means not only the right of the citizen to be free from the mere physical restraint of his person, as by incarceration, but the term is deemed to embrace the right of the citizen to be free in the enjoyment of all his faculties; to be free to use them in all lawful ways; to live and work where he will; to earn his livelihood by any lawful calling; to pursue any livelihood or avocation, and for that purpose to enter into all contracts which may be proper, necessary and essential to his carrying out to a successful conclusion the purposes above mentioned.

241. Id. at 590-91:

Has not a citizen of a State, under the provisions of the Federal Constitution above mentioned, a right to contract outside of the State for insurance on his property-a right of which state legislation cannot deprive him? We are not alluding to acts done within the State by an insurance company or its agents doing business therein, which are in violation of the state statutes. Sucl acts come within the principle of the Hooper case [155 U.S. 648 (1895)], and would be controlled by it. When we speak of the liberty to contract for insurance or to do an act to effectuate such a contract already existing, we refer to and lave in mind the facts of this case, where the contract was made outside the State, and as such was a valid and proper contract.

242 Id. at $591-92$ 
tional market. The Court might ordinarily be thought to pursue such a policy through decisions grounded in the dormant Commerce Clause, but the Court had previously held that "[ $t]$ he busmess of insurance is not commerce. ${ }^{, 243}$ It therefore used substantive due process doctrine to serve this end.

The Taft Court freely deployed the doctrine of substantive due process in order to safeguard the structural integrity of the national market. Even Holmes would build on Allgeyer to hold that Arkansas could not impose a five percent tax on premiums paid by Arkansas residents to out-of-state imsurance companies not authorized to do business in Arkansas. ${ }^{244}$ Holmes read Allgeyer to stand for the proposition that although "the State may regulate the activities of foreign corporations within the State," it "carmot regulate or interfere with what they do outside."245 In Compañia General de Tabacos de Filipinas v. Collector of Internal Revenue, ${ }^{246}$ the Taft Court struck down a Philippine statute imposing a tax on extrajurisdictional contracts with foreign imsurance comparies not hicensed to do business in the Philippines. ${ }^{247}$ It read Allgeyer to stand for the proposition that a state "may

243. Hooper v. California, 155 U.S. 648, 655 (1895); see also Paul v. Virginia, 75 U.S. (8 Wall.) 168,183 (1868) ("Issuing a policy of insurance is not a transaction of commerce."). In Allgeyer, therefore, the Court started from the premise that

[t]lhere is no doubt of the power of the State to prohibit foreign insurance companies from doing business within its limits. The State can impose such conditions as it pleases upon the doing of any business by those companies within its borders, and unless the conditions be complied with the prohibition inay be absolute. The cases upon this subject are cited in the opinion of the court in Hooper v. California .... .

165 U.S. at 583.

244. St. Louis Cotton Compress Co. v. Arkansas, 260 U.S. 346, 348-49 (1922).

245. Id. at 349.

246. 275 U.S. 87 (1927).

247. Id. at 98. Taft authored the Court's opinion. We have extant a letter from Van Devanter to Taft, arguing that even "[g]ranted that the property as such was taxable while in the Phile ippines, that affords no ground for saying that the Philippine government may tax transactions and business done outside the jurisdictional limits of that government." Letter from Willis Van Devanter to William Howard Taft (Nov. 11, 1927), Taft Papers, supra note 104, Reel 296. One can discern a good deal about the internal dynamics of the Taft Court from Taft's return note to Van Devanter on November 16:

I send you herewith my opinion .... I wish you would look this over and let me know what you think about the solution here suggested. I am sending this to Pierce and to Mac, and I am sending it also to Stone, because you know he voted with us, before I circulate it.

Letter from William Howard Taft to Willis Van Devanter (Nov. 16, 1927), id. On that sante day, Taft wrote McReynolds that "Brandeis and Holmes liave been talking with Stone, and I don't know whether he will stay put or not." Letter from William Howard Taft to James C. McRey. nolds (Nov. 16, 1927), id. Holmes dissented in the case, joined by Brandeis. The dissent is nota- 
not compel any one within its jurisdiction to pay tribute to it for contracts or money paid to secure the benefit of contracts made and to be performed outside of the state. ${ }^{24+8}$

The nationalism imphicit in these cases is not that of congressional power. It would not be until 1944 that the Supreme Court would overrule almost seventy years of doctrine to hold that Congress could regulate imsurance as part of its authority to control interstate commerce. ${ }^{249}$ Instead the Court self-consciously employed federal judicial power to define imdividual constitutional rights to serve the distinctively structural value of preventing the balkanization of the national market.

The "increasimgly nationahistic outlook that marked the Supreme Court in the 1920 s"20 $^{\text {"20 }}$ was dramatically visible in its efforts to ensure that national corporations would retain access to federal courts and hence to a uniform federal law. The point is well illustrated by the case of Terral v. Burke Construction Co. ${ }^{251}$ In 1921 it was common practice for states legislatively to restrict the access of foreign corporations to federal courts. ${ }^{22}$ The roots of the practice went back to a strongly pro-states' rights decision im 1868 holding that states had a virtually free hand in regulating foreign corporations. ${ }^{253}$ Because it

ble for its famous aperçu that "Taxes are what we pay for civilized society, including the chance to insure." Compañia Gen, 275 U.S. at 100 (Holmes, J., dissenting).

248. Compañia Gen., 275 U.S. at 94-95. "To say that this tax results in some prohibition of foreign business and so is invalid, amounts to saying that no tax on foreign contracts is legal. So the case seems necessarily to decide that a tax on acts outside the state is unconstitutional." Note, Taxation-May a State Levy a Tax on Acts Done Outside the State?, 26 MICH. L. REV. 803, 804 (1928); see also Note, State Regulation of Foreign Made Contracts Under the Fourteenth Amendment, 41 HARV. L. REv. 390, 393 (1928) ("The doctrine of the Allgeyer case inust, therefore, rest on the idea that the due process clause incorporated the common law notion that a state's jurisdiction extends no further than its borders."). For a general discussion of the cases, see generally Nathan Greene, The Allgeyer Case as a Constitutional Embrasure of Territoriality, 2 ST. JOHN'S L. REv. 22 (1927); Thomas Reed Powell, The Supreme Court and State Police Power, 1922-1930 (pt. 5), 18 VA. L. REv. 131, 150-57 (1931).

249. United States v. South-Eastern Underwriters Ass'n, 322 U.S. 533, 553 (1944). On the special circumstances of the imsurance industry in the 1920s, see PURCELL, supra note 148, at 205-13.

250. PURCELL, supra note 148, at 192.

251. 257 U.S. 529 (1922).

252. About half of the states imposed such restrictions. PURCELL, supra note 148, at 205.

253. Paul v. Virginia, 75 U.S. (8 Wall.) 168, 181 (1868):

Now a grant of corporate existence is a grant of special privileges to the corporators, enabling them to act for certain designated purposes as a single individual, and cxempting them (unless otherwise specially provided) from individual liability. The corporation being the mere creation of local law, can lave no legal existence beyond the limits of the sovereignty where created.... The recognition of its existence even by other States, and the enforcement of its contracts inade therein, depend purely upon 
believed that states could exclude foreign corporations altogether, the Court liad originally approved statutes allowing foreign corporations to engage in business in a state only upon condition that they refrain from suing in federal court or from removing cases to federal courts. ${ }^{234}$ But the Court soon had second thoughts, and the result was a stream of waffling precedents that could not "be reconciled.",2ss Terral finally and forcefully overruled prior precedents to establish the unambiguous principle "that a State may not, in imposing conditions upon the privilege of a foreign corporation's doing business in the State, exact from it a waiver of the exercise of its constitutional right to resort to the federal courts. ${ }^{2256}$ Writing for the Court, Taft announced:

\begin{abstract}
the comity of those States-a comity which is never extended where the existence of the corporation or the exercise of its powers are prejudicial to their interests or repugnant to their pohicy. Having no absolute right of recognition in other States, but depending for such recognition and the enforcement of its contracts upon their assent, it follows, as a matter of course, that such assent may be granted upon such terms and conditions as those States may think proper to impose. They nuay exclude the foreign corporation entirely; they may restrict its business to particular localities, or they may exact such security for the performance of its contracts with their citizens as in their judgment will best promote the public interest. The whole matter rests in their discretion.
\end{abstract}

254. Doyle v. Cont'l Ins. Co., 94 U.S. 535, 542 (1876).

255. Terral, 257 U.S. at 532.

256. Id. Edward Purcell writes that after Terral, "[f]or the first time since the corporate system developed in the $1870 \mathrm{~s} . .$. insurers had unrestricted and unproblematic access to federal courts across the nation. They wasted no time in taking advantage of the opportunity." PURCELL, supra note 148, at 205. Former congressman George K. Denton wrote Taft that "by reason of the recent holding of the United States Supreme Court that forcign corporations may remove causes into the Federal Court even though they are not engaged in Interstate Commerce," he expected "that almost all imsurance cases where the amount involved is more that [sic] $\$ 3000$ will be removed by one party or the other and this is true I think of corporation cases generally." Letter froun George K. Denton to Wilhiam Howard Taft (Dec. 27, 1922), Taft Papers, supra note 104, Reel 248 . He predicted that federal dockets would soon be clogged.

Terral was understood to revive the doctrine of "unconstitutional conditions," which the Court had initially developed to regulate state prohibitions on forcign corporations. For a discussion of the doctrine, see GERARD CARL HENDERSON, THE POSITION OF FOREION CORPORATIONS IN AMERICAN CONSTTTUTIONAL LAW 132-47 (1918). Like the conteniporary Court, however, the Taft Court experienced great difficulties in cstablishing a clear or consistent account of this doctrine. Compare Packard v. Banton, 264 U.S. 140, 144 (1924) ("The streets belong to the public and are primarily for the use of the public in the ordimary way. Their use for the purposes of gain is special and extraordinary and, generally at least, may be prohibited or conditioned as the legislature deems proper."), with Frost \& Frost Trucking Co. v. R.R. Comm'n, 271 U.S. 583, 593-94 (1926):

It would be a palpable incongruity to strike down an act of state legislation which ... seeks to strip the citizen of rights guaranteed by the federal Constitution, but to uphold an act by which the same result is accomplished umder the guise of a surrender of a right in exchange for a valuable privilege which the state threatens otherwise to withhold.... [The state] may not impose conditions which require the relinquishment of constitutional rights. 
The principle does not depend for its application on the character of the business the corporation does, whether state or interstate, although that has been suggested as a distinction in some cases. It rests on the ground that the Federal Constitution confers upon citizens of one State the right to resort to federal courts in another, that state action, whether legislative or executive, necessarily calculated to curtail the free exercise of the right thus secured is void because the sovereign power of a State in excluding foreign corporations, as in the exercise of all others of its sovereign powers, is subject to the limitations of the supreme fundamental law. ${ }^{257}$

257. Terral, 257 U.S. at 532-33. In Kline v. Burke Construction Co., 260 U.S. 226 (1922), the Court corrected Taft's enthusiastic implication that the right to resort to federal courts, whether by filing a cause of action or by removal, was a constitutional right. Instead, the Court said, it was not a right "derived from the Constitution of the United States, unless in a very indirect sense. Certainly it is not a right granted by the Constitution." Id. at 233. The Constitution merely authorized Congress to create or withdraw access to lower federal courts. "The Constitution simply gives to the inferior courts the capacity to take jurisdiction in the enumerated cases, but it requires an act of Congress to confer it" Id. at 234; see also PURCELL, supra note 148, at 207.

Terrals forceful effort to protect federal diversity jurisdiction was typical of the Taft Court. In the Term after Terral, for example, in Lee v. Chesapeake \& Ohio Railisay Co., 260 U.S. 653 (1923), the Court reached out to overturn another precedent, Ex parte Wisner, 203 U.S. 449 (1906), which had held that cases brought in a state court jurisdiction in which neither party resided could not be removed to federal district courts under diversity jurisdiction, because venue would have been improper as an original matter. Wisner, 203 U.S. at 460-61. For a discussion of Lee and Wisner, see PURCELL, supra note 148, at 191-93. Wisner had caused endless difficulties. See, eg., In re Moore, 209 U.S. 490, 507 (1908) (noting that the IYisner holding did not apply where the parties consented to the jurisdiction of a federal district court); Note, Removal of Causes When Neither Party Is a Resident of the State in Which Suit is Brought, 71 U. PA. L. REV. 242, 246 (1923) (arguing that "[t]he Wisner case and those Federal cases following it have confused general jurisdiction with venue, and caunot be supported on reason"). Aggressively reaching out definitively to settle "a much disputed question," Current Decision, Lee v. Chesapeake \& Ohio Ry. Co., 260 U.S. 653 (1923), 32 YALE LJ. 747, 747 (1923), the Court in Lee unanimously determined to pronounce Wisner "essentially unsound and definitely to overnule it," 260 U.S. at 660 . Shortly after Lee was announced, Van Devanter, who authored the opinion, wrote a friend to explain the import of the decision:

Of recent years there has been very great difficulty about the jurisdiction of District Courts on removals from state courts, and the matter reaclied a stage of intolerable uncertainty and diverging opinions. Some of the District Courts were remanding cases which others retained. Removals were made froin state courts such as Washington and Montana to the District Courts in New Jersey and Maryland. A District Court in New York declined to remand a cause which had been removed into it from a state court in Vermont. Some of the District Judges said the matter was very plainly settled one way and others asserted with equal confidence that it was settled the other way. Some were frank enough to tell the truth and say that the whole matter was in great confusion. All of this was due to two very unfortunate decisions in our court. The first was the Wisner, in 203 U.S., and the second was the Moore case, in 209 U.S. There were later decisions following both in an indulgent way and attempting to explain them, although logically that was impossible. The Wisner case was dead wrong, but was consisteut with itself. The Moore case was a miscrable straddle and not really in accord with anything. It tried to correct the Wisner case and did so in a degree, but 
The Taft Court built energetically on the precedent of Terral ${ }^{238}$ to erect judicial barriers against the balkanization of the national market. The Court evidenced great concern to prevent local discrimination against foreign corporations. In Fidelity \& Deposit Co. v. Tafoya, ${ }^{259}$ Holmes held that although a "State has the power and constitutional right arbitrarily to exclude" a foreign corporation, it could not do so "as part of a scheine to accomplish a forbidden result." 260

Thus the right to exclude a foreign corporation cannot be used to prevent it from resorting to a federal court, Terral v. Burke Construction Co., 257 U.S. 529; or to tax it upon property that by estabhished principles the State has no power to tax, Western Union Telegraph Co. v. Kansas ...; or to interfere with interstate commerce, Sioux Remedy Co. v. Cope .... A State cannot regulate the conduct of a foreign railroad corporation in another jurisdiction, even though the Company has tracks and does business in the State making the attempt. New York, Lake Erie \& Western R. R. Co. v. Pennsylvania $\ldots$. $^{26}$

Tafoya struck down a New Mexico statute that forbade foreign insurance companies from paying nonresidents of New Mexico "for the obtaining, placing or writing of any policy ... of insurance covering risks" within the state. ${ }^{262}$

it did not strike it down. I wrote a couple of opinions this term which I believe have untangled the subject and substituted order for chaos.

Letter from Willis Van Devanter to A.C. Campbell (Mar. 6, 1923), Van Devanter Papers, supra note 116. John Clarke, retired from the Court at the time of Lee, wrote to Van Devanter after the decision that it was

in your best vein and does what should have been done years ago. It was one of those unfortunate straddles which some men persuade themselves are very astute \& which others let pass rather than oppose. You clean it up nicely \& make me more confident even than your letter did that all is well.

Letter from John H. Clarke to Willis Van Devanter (Mar. 2, 1923), id.

258. On the contemporary importance of Terral, see Frost \& Frost Trucking Co. v. R.R. Comm'n, 271 U.S. 583, 594-95 (1926) (discussing the effects of Terral on previous Court decisions).

259. 270 U.S. 426 (1926).

260. Id. at 434; see also Pahnetto Fire Ins. Co. v. Connecticut, 272 U.S. 295, 304 (1926) (citing Tafoya for the principle that the state may not use the power to exclude to accomplish an unconstitutional result).

261. Tafoya, 270 U.S. at 434-35.

262. Id. at 433,436 . New Mexico sought to justify the law as a prophylactic

to prevent the use of dummy agents in the State. It was suggested that agents were paid by commissions at well known conventional rates, and that the statute meant to forbid the dividing of these commissions, and in that way to prevent the work being 
In Hanover Fire Insurance Co. v. Harding, ${ }^{23}$ the Court acknowledged "that foreign corporations can not do business in a State except by the consent of the State; that the State inay exclude them arbitrarily or impose such conditions as it will upon their engaging in business within its jurisdiction," yet it also held that "a number of decisions of recent years" ${ }^{364}$ had demonstrated important limitations on this power:

[T] he State may not exact as a condition of the corporation's engaging in business within its limits that its rights secured to it by the Constitution of the United States may be infringed. This is illustrated ... in cases in which a provision of a state law revoking the license of a foreign corporation for exercising its constitutional right to remove suits brought against thein from the state courts to the federal courts, has been held void, Terral v. Burke Construction Company, 257 U.S. 529; in cases in which the State has vainly attenipted to subject foreign corporations to a payment of a tax which is a tax not only on the property of the corporation in the State but also on its property without the State, in violation of the due process clause of the Fourteenth Amendment,... St. Louis Cotton Compress Company v. Arkansas, 260 U.S. 346; and finally in cases of a

done and paid for elsewhere, while nominal agents in New Mexico were paid small sums for the use of their names. In short, it is said the purpose was to secure responsible men to represent the Company on the spot.

Id. at 435. In the original draft of his opinion, Holmes had continued after this passage: "We are far from saying that such a purpose was not legitimate or that the State might not use all its powers to accomplish it." Fidelity \& Deposit Co. v. Tafoya file, Holmes Papers, supra note 68. Butler, however, objected to the sentence.

I think the State without power to forbid payment for work done outside to secure business within, and that the Company and its "agents" in New Mexico may make their own arrangements as to compensation. At any rate, the statements and implications imdicating the contrary seem unnecessary. Is it not enough to take the statute at what it says \& condemn it?

Id. Van Devanter agreed with Butler: "I am not prepared to go so far. An agent who does only half the work cannot be entitled to full commission by mere legislative edict-at least I should not want to say... that now." Id. Taft also chimed in: "I suggest that it is not wise for us to decide in this case more than we have to decide. I hesitate to intimate what our views might be on a statute differently drawn. It might return to plague us." Id. Taft also wrote separately to Sutherland to report that:

Van Devanter is disposed to criticise the language ... that I have marked ... as intimating an opinion as to what we unight think of the statute if it made another provision. I agree with him that it is wiser not to give our opinion on another act than the one we have before us.

Letter from William Howard Taft to George Sutherland (Jan. 13, 1926), Sutherland Papers, sthpra note 118 . Holmes eventually removed the sentence.

263. 272 U.S. 494 (1926).

264. Id. at 507. 
class to which it is contended the present case belongs, where a tax or license law operates to deny to the foreign corporation the equal protection of the laws,... Air Way Corporation v. Day, 266 U.S. $71^{265}$

The Court in Harding struck down as violative of equal protection a discriminatory tax on foreign corporations. ${ }^{266}$ In Power Manufacturing Co. v. Saunders, ${ }^{267}$ the Court struck down as inconsistent with equal protection an Arkansas statute that required suits against domestic corporations to be brought "in a county where it has a place of business or in which its chief officer resides," but which allowed suits against foreign corporations to be brought "in any county in the State." ${ }^{268}$ Arkansas defended the statute on the ground that foreign corporations "impliedly assented to the venue provisions," but the Court rejected this argument, citing Taft Court precedents to the effect "that a foreign corporation by seeking and obtaining permission to do business in a State does not thereby become obligated to comply with or estopped from objecting to any provision in the state statutes which is in conflict with the Constitution of the United States."269

265. Id. at 507-08.

266. The opinion was unanimous. Brandeis wrote Taft,

I hope you will consent to delete so much of [your opinion] as finds discrimination in the immunity of foreign casualty corporations from the tax. I think this is not shown to be an arbitrary classification.... You have threaded your way skillfully through a labyrinth beset with dangers; and I should be sorry to have to withhold assent to your opinion.

Letter from Louis D. Brandeis to William Howard Taft (Nov. 2, 1926), Taft Papers, supra note 104, Reel 279.

267. 274 U.S. 490 (1927); see also Ky. Fin. Corp. v. Paramo1mt Auto Exch. Corp., 262 U.S. 544,551 (1923) (invalidating a statute for denying equal protection to the plaintiff corporation).

268. 274 U.S. at 491-92. The decision was characterized as "the culmination of a scries of cases extending the safeguard of the equal protection clause to foreign corporations." Recent Case, Power Mfg. Co. v. Saunders, 274 U.S. 409 (1927), 41 HARV. L. REv. 95, 95 (1927).

269. Saunders, 274 U.S. at 496-97. The Court cited Harding and Frost \& Frost Trucking Co. v. Railroad Commission, 271 U.S. 583 (1926). Id. at 497. In dissent, Holmes, joined by Brandeis, refused to extend the logic of Tafoya to the question of equal protection:

In order to enter into most of the relations of hife people have to give up some of their Constitutional rights. If a man makes a contract he gives up the Constitutional right that previously he had to be free from the hamper that he puts upon himself. Soune rights, no doubt, a person is not allowed to renounce, but very many he may. So we must go further than merely to point to the Fourteenth Amendment. I sce nothing in it to prevent a foreign corporation agreeing with the State that it will be subject to the general law of torts and will submit to a transitory action wherever it may be sued.... While we adhere to the rule that a State may exclude foreign corporations altogether it seems to me a inistake to apply the inequality clause of the Fourteenth Amendment with meticulous micety. The Amendment has been held not to overthrow ancient practices even when hard to reconcile with justice. I think there are stronger grounds 
The elite bar in Arkansas applauded the decision, because in their view the venue statute liad kept "foreign capital out of Arkansas."2070

\section{B. Federal Common Law and Judicial Centralization}

Central to the Taft Court's understanding of the national market was the doctrine of Swift $v$. Tyson, ${ }^{271}$ which declared that, in diversity cases, federal courts could decide cases by reference to federal coinmon law, or "general law, not based on any legislation of the State or local law or usage."272 Because nationwide corporations could generally imvoke federal diversity jurisdiction, federal common law estab-

for not reducing the power of the States to attach conditions to a consent that they have a right to refuse, when there is no attempt to use the conditions to invade forbidden fields.

Id at 497-98 (Holmes, J., dissenting). Van Devanter, who authored Saunders, was appalled by Holmes's dissent. He sent a copy of the opinion to his close friend Walter Sanborm, chief judge of the Eighth Circuit, commenting "I particularly ask you to look at the dissenting opinion. I hardly know what would be left if it were the prevailing opinion." Letter from Willis Van Devanter to Walter H. Sanborn (June 4, 1927), Van Devanter Papers, supra note 116. Sanbom answered,

I am very glad that you and your associates who agree with you in this opinion and others like it control the Supreme Court of the United States. If instead of Justices Sutherland, Butler and Stone there had been placed upon the Supreme Court gentlemen whose minds naturally run in accord with the views of the dissenters in this case, it seems to ine that the personal rights and property rights of the citizens and corporations of the United States would have been without protection.

Letter froin Walter H. Sanborn to Willis Van Devanter (June 15, 1927), id.

270. Letter from George B. Rose to Willis Van Devanter (June 8, 1927), Van Devanter Papers, supra note 116. Rose, a noted legal author, wrote Van Devanter to praise Saunders:

The decision ... is not only right in principle; but it is one of the greatest blessings that ever came to our State. Petty lawyers interested in damage suits against foreign corporations have kept this infamous statute upon the books and have harrassed [sic] such corporations by bringing suits in the most remote counties, and often in counties where the cards had been stacked against the defendant; and nothing has done so much to keep foreign capital out of Arkansas. It is the honest people of the State who will be the greatest beneficiaries of this epoch-making decision; but no doubt its benefits will be felt in inany other jurisdictions.

Id. Van Devanter was so pleased with the Rose letter that he sent an excerpt of it to Taft. Letter from Willis Van Devanter to Williain Howard Taft (June 13, 1927), Van Devanter Papers, supra note 116.

271. 41 U.S. (16 Pet.) 1 (1842).

272. Salem Trust Co. v. Mfrs.' Fin. Co., 264 U.S. 182, 191 (1924). Although there were a few narrow exceptions, federal courts generally viewed themselves as bound by state statutes and state interpretations of such statutes. Risty v. Chi., Rock Island, \& Pac. Ry. Co., 270 U.S. 378, 387 (1926); Edward Hines Yellow Pine Trs. v. Martin, 268 U.S. 458, 462, 464 (1925); Mason v. United States, 260 U.S. 545, 557 (1923). 
hished a distinct, and generally pro-business ${ }^{273}$ law that could serve as the instrument of "a uniform policy toward interstate business." 274 The nationalisin of this vision was quite explicit. As Taft remarked in 1922:

Another test of the trained self-restraint of the American people is the constitutional and statutory provisions enabling non-residents to avoid the assumed local prejudice of state courts against them by trying their controversies with home people in Federal Courts. ... It is not too much to say, however, that few factors in the rapid growth of the newer parts of the country have been more effective than the knowledge by those whose confidence and capital were needed to build up that new country that the Constitution and the laws of the nation furnished a national court wholly impartial between citizens of all the states in which their contracts and property rights, though they were non-residents, could be adjudged and protected. Such courts have in an imdirect but most strikingly effective way united the sections of the country in a common effort to develop our great resources.

273. Tony A. Freyer, The Federal Courts, Localism, and the National Economy, 1865-1900, 53 BUS. HIST. REV. 343, 355 (1979) ("II]t was fairly well acknowledged that federal courts favored national business-which was usually corporate business.").

274. Id. at 362. "The virtues of the Swift v. Tyson idea as a device for achieving national uniformity," reınarked Grant Gilmore, "are obvious." GRANT GILMORE, THE AGES OF AMERICAN LAW 34 (1977). As the American Bar Association opimed in 1882, federal common law was the law "not of one state, but of all the states; not of a section, but of the entire people; not of local interests, but of the general welfare. It is the only homogeneous law we have." Special Comm., Am. Bar Ass'n, Minority Report on the Relief of the United States Courts, in REPORT OF THE FIFTH ANNUAL MEETING OF THE AMERICAN BAR ASSOCIATION 378 (1883); see also TONY FREYER, HARMONY \& DISSONANCE: THE SWIFT \& ERIE CASES IN AMERICAN FEDERALISM 81-82 (1981) (discussing the report's support for Swift). In 1932 Judge John J. Parker could passionately assert that "[n]o power exercised under the Constitution has, in my judgment, had greater influence in welding these United States into a single nation" than federal diversity jurisdiction. John J. Parker, The Federal Jurisdiction and Recent Attacks Upon 1t, 18 A.B.A. J. 433, 437 (1932). "[N]othing has done inore to foster interstate commerce and communication and the uninterrupted flow of capital for investment into the various parts of the Union; and nothing has been so potent in sustaining the public credit and the sanctity of private contracts." Il. Diversity jurisdiction, Parker argued, created a "uniformity of decision throughout the United States in inatters of general law." Id. at 438.

275. Williain Howard Taft, At the Cradle of Its Greatness, Address at the Rededication of the Old Supreme Court Building in Philadelphia (May 2, 1922), in 8 A.B.A. J. 333, 335 (1922). "[N]o single element in our governmental system has done so much to secure capital for the le. gitimate development of enterprises throughout the West and South," Taft declared, "as the existence of federal courts there, with a jurisdiction to hear diverse citizenship cases." William Howard Taft, Possible and Needed Reforms in Administration of Jistice in Federal Courts, 8 A.B.A. J. 601, 604 (1922). Taft had been expressing this same view since 1895. See, e.g., William Howard Taft, Criticisms of the Federal Judiciary, Address Before the American Bar Association (Aug. 28, 1895), in 29 AM. L. REV. 641, 658-59 (1895) (discussing the importance of diversity jurisdiction to the developinent of new states). Brandeis quite explicitly disagreed with 
Federal common law was driven by the perceived needs of national structure. As one opponent of federal diversity jurisdiction argued in Congress, federal common law constituted the "centralization of power in the Federal Government" and the "obliteration of State lines." 276 Just as the Taft Court was willing to countenance national uniformity imposed by Congress in the Transportation Act of 1920, or the Packers and Stockyards Act of 1921, or the Grain Futures Act, so it was itself willing to contribute to such uniformity througl the medium of judicial decisionmaking. But whereas Bailey and the Court's decisions interpreting federal antitrust law suggest that federal control of ordinary property or freedom of contract would sometimes arouse the Court's anxiety to preserve a separate and exclusive sphere of state police power, applying federal common law to ordinary commercial transactions did not seem to trigger any of the structural reservations that dual sovereignty might be thought to suggest.

If one regards federalisin as addressed merely to the quantitative distribution of power between state and federal governments, this distinction is puzzling. General federal common law offered a uniform and substantive set of national rules that potentially displaced ordi-

Taft's position. In August of 1924, he said to Frankfurter that "claims as to what investors will do, what will or won't frighten [them] off" were grossly exaggerated. Urolsky, supra note 70, at 331. The "truth" is, Brandeis asserted, that "pressure of money \& pressure of its manipulation (bankers) lead to imvestment \& no causal connection between decisions \& legislation \& refusal to invest." Id. Frankfurter later published an article reasserting Brandeis's position:

[I]t is urged that eastern investments in the west and south are exposed in state tribunals to the risks of unfaimess toward non-resident capital. This is an old claim, and has the monentum of constant repetition. But, surely, the argument is theoretical. Bankers, and still less investors, do not contemplate litigation for default when they inake loans. What rate they get depends mainly on the money market and the credit of borrowers.

Felix Frankfurter, Distribution of Judicial Power Between United States and State Courts, 13 CORNELL L.Q. 499, 521 (1928). Tony Freyer, however, argues that "the federal courts" were in fact "instrumental in overcoming local resistance to national business during the late nineteenth century." Freyer, supra note 273 , at 344.

276. 10 CONG. REC. 1278 (1880) (statement of Rep. Richard V. Townshend); see also FREYER, supra note 274, at 79-80 (reproducing some of Townshend's remarks). Read in full, Townshend's observations invoke the classic themes of federalism:

What does all this mean? It is easily to be seen that it means centralization of power in the Federal Government. It means a distrust of the capacity of the people for selfgovernment .... It means a strong government. It means an obliteration of State lines and the degradation of the State judiciary.

10 CONG. REC 1278 (1880) (statement of Rep. Richard W. Townshend). Harry Scheiber characterizes the development of federal common law as a "centralizing doctrinc of major import." Harry N. Scheiber, Federalism and the American Economic Order, 1789-1910, 10 LAW \& SOC"Y REv. 56, 102 (1975). On the scope of federal cominon law, see Erie R.R. Co. v. Tompkins, 304 U.S. 64, 75-76 (1938) (discussing the diverse topies addressed within "gencral law"). 
nary state judicial decisionmaking. Evidently, however, national common law stood in a different relationship to local self-government than did congressional legislation. In contrast to the potentially bureaucratic and oppressive nature of federal legislation, ${ }^{277}$ the dominant view in the 1920 s regarded state and federal common law as "springing from custom" that embodied "the experience of free men." 278 Taft put it in 1905, whereas "under the civil law the state seems a separate entity, different from the people who constitute it, ... at the common law the theory is that the state is ... a great partnership in which [the individual] has a voice.",279

It was this profound (and to modern eyes baffling) identification of the common law with "the people" that ultimately justified the Court's confidence in its own authority correctly to discern the "pubhic inorals" of the country, even in defiance of a contrary congressional judgment. This authority empowered the Court to discern core American values that transcended structural divisions between national and local spheres of power. ${ }^{280}$ Prominent among such values were "those privileges long recognized at common law as essential to the orderly pursuit of happiness by free men."281 From this perspective, the enforcement of common law rights was prerequisite for individual hberty, as well as for the very practice of local selfgovernment. ${ }^{282}$ That is why the Court seems never to have conceived itself as an arm of a national sovereignty that was distinct from and

277. See supra notes 197-204 and accompanying text.

278. Charles Evans Hughes, American Lawyers Welcomed in Historic Westminster Hall, Response on Behalf of the American Bar Association (July 21, 1924), in 10 A.B.A. J. 567, 569 (1924).

279. William Howard Taft, The Administration of Criminal Law, 15 YALE L.J. 1, 2 (1905). Taft understood the common law to fuse persons and the state into a "partnership" because he saw the common law as a form of "customary law handed down from one generation to another," and therefore as growing out of the people themselves. William Howard Taft, The Selection and Tenure of Judges, in REPORT OF THE THIRTY-SIXTH ANNUAL MEETING OF THE AMERICAN BAR ASSOCIATION 419-20 (1913).

280. See supra notes 231-32 and accompanying text.

281. Meyer v. Nebraska, 262 U.S. 390, 399 (1923). These privileges, the Court observed, aro the distinguishing marks of American democracy:

In order to submerge the individual and develop ideal citizens, Sparta assembled the males at seven into barracks and intrusted [sic] their subsequent education and training to official guardians. Although such measures have been deliberately approved by men of great gemus, their ideas touching the relation between individual and State were wholly different from those upon which our institutions rest.

Id. at 402.

282. Post, supra note 10 , at $1537-39$. 
potentially competitive with the states. ${ }^{253}$ Instead the Court imagined itself as the fountainhead of the very rights that gave vibrancy and meaning to the life of free men and thereby to the institutions of local self-government.

Debates over the legitimacy of federal common law were quite common in the early twentieth century. We tend now to read these debates as concerned primarily with the question of whether federal courts had power to make law. But underlying this question was the deeper issue of whether federal courts had the authority to speak for a pervasive national ethos that transcended structural distinctions between state and national sovereignty. Although federal courts ultimately would renounce this authority after Erie Railroad Co. v. Tompkins, ${ }^{284}$ the Taft Court still cherished it, viewing it as an essential aspect even of its function as a constitutional tribunal.

This fusion of common and constitutional law was typical of the Court's federalism jurisprudence in the 1920s. It is visible in the decade's most controversial application of federal common law, the case of Black \& White Taxicab \& Transfer Co. v. Brown \& Yellow Taxicab

283. The Taft Court's jurisprudence of judicial comity is an execption to this generalization. The Taft Court persistently evinced great sensitivity to the fact that "[i]n this country, in which in every state we have courts of concurrent jurisdiction under the federal and state authority, it is of the highest importance that conflict of juristiction should be avoided. It can only be avoided by forbearance and comity...." Harkin v. Brundage, 276 U.S. 36, 55 (1928); see also, e.g., Rhea v. Smith, 274 U.S. 434, 441-45 (1927) (reconciling the applicability of state and federal statutes concerning liens upon real estate); Fenner v. Boykin, 271 U.S. 240, $243-48$ (1926) (declining to apply Ex Parte Young to enjoin a state court proceeding); Harrigan v. Bergdoll, 270 U.S. 560, 564-65 (1926) (enforcing a state statute of limitations); Cent. Union Tel. Co. v. Edwardsville, 269 U.S. 190, 195 (1925) (upholding a state-law procedural waiver of the plaintiff's federal constitutional claims); United States ex rel. Kennedy v. Tyler, 269 U.S. 13, 19 (1925) (vindicating New York's judicial power over Native American lands); Kline v. Burke Constr. Co., 260 U.S. 226 (1922). The Taft Court sought to maintain a delicate balance between national supremacy and respect for state courts. In Davis v. Corona Coal Co., 265 U.S. 219 (1924), for example, the Court, per Justice Holmes, refused to accept a state law procedural defense to the assertion of a federal claim. Holmes observed that "[p]erhaps it was not quite fully remembered that the laws of the United States are a part of the lex fori of a state." Id. at 222. Taft wrote Holmes in response to this opimion that "I don't inind a little lecture to state courts that they are still within the Urited States." William Howard Taft, Annotation to Circulated Draft Opinion in Davis v. Corona Coal Co., Holmes Papers, supra note 68. In Lion Bonding \& Surety Co. v. Karatz, 262 U.S. 77 (1923), by contrast, the Court, per Justice Brandeis, scolded a lower federal court for seeking to divest a state court of jurisdiction in the context of a reccivership. "Lower federal courts," Brandeis wrote, "are not superior to state courts." Id. at 90 . Taft wrote Brandeis about this sentence that it "would seem to state the obvious, but whatever many District \& Circuit Judges would assent in this regard, the fact is that in their hearts they feel otherwise. The opinion will do a world of good." William Howard Taft, Annotation to Circulated Draft Opinion in Lion Bonding \& Surety Co. v. Karatz, Brandeis Papers, supra note 116. Brandeis was quite clear that "questions of jurisdiction are really questions of power between States and Nations [sic]." Urofsky, supra note 70, at 313.

284. 304 U.S. 64 (1938). 
\& Transfer $C 0^{285}$ The facts of the case were particularly embarrassing. The Brown \& Yellow Taxicab Company had entered into a contract with the Louisville \& Nashville Railroad Company for the exclusive privilege of servicing the road's depot at Bowling Green. Such exclusive contracts, however, were unenforceable under Kentucky law; they were deemed monopohistic and contrary to public policy. ${ }^{286}$ Not to be deterred, the Brown \& Yellow Coinpany, with the support of the railroad, promptly reincorporated itself $\mathrm{m}$ Tennessee and invoked diversity jurisdiction to bring suit against the railroad and a competi-

285. 276 U.S. 518 (1928); see Erie R.R. Co., 304 U.S. at 73 ("Criticism of the doctrine became widespread after the decision of Black \& White Taxicab Co."). Within the Court, there had been a sharp exchange about federal common law the previous Term in the case of Empire Trust Co. v. Cahan, 274 U.S. 473 (1927). The case came up in diversity and concerned the standard of hability to which a bank could be held for honoring fraudulent checks. The Second Circuit had virtually imposed strict hability upon the bank, but the Supreme Court, in a unanimous opinion by Holmes, reversed, articulating a standard close to that created by New York law. In his opinion, Holmes reasoned:

It is very desirable that the decision of the Courts of the United States and that of the highest Court of the State where the business was done, should agree, as was recognized by the Circuit Court of Appeals. The result to which we come restores that agreement, at least when the checks are certified or accepted by the banks upon which they are drawn, as was the case here with all but two. Whiting v. Hutlson Trust Co., 234 N.Y. 394.... As the Court remarks in the case cited "The transactions of banking in a great financial center are not to be clogged, or their pace slackened, by over-burdensome restrictions." 234 N.Y. 406.

$I d$. at 480 . In its original draft, this paragraph had read:

It is very desirable, to say the least, that the decision of the Courts of the United States and that of the highest Court of the State where the busimess was done, should agrec, as was recognized by the Circuit Court of Appeals. The result to which we coine restores that agreement, at least when the checks are certified or accepted by the banks upon which they are drawn, as was the case here with all but two. Whiting v. Huldson Trust Co.... We should expect that when necessary the Coutt of Appeals would take the further step of applying the same principle to uncertified checks.... As the Court remarks in the case cited "The transactions of banking im a great financial center are not to be clogged, or their pace slackened, by over-burdensome restrictions."

Empire Trust Co. v. Cahan file, Holmes Papers, supra note 68 (quoting Whiting v. Hudson Trust Co., 138 N.E. 33, 37 (N.Y. 1922)) (emphasis added). Butler marked the paragraph and commented: "It seems to me better to omit the implication that the decision ought to be bound by the decisious of the State Court. The rule that this Court is not so bound is so well known and has been followed so long that we would better adhere to it. Moreover, no expression on the point is necessary in this case." Pierce Butler, Annotation to Circulated Draft Opinion in Empire Trust Co. v. Cahan, Holmes Papers, supra note 68. Taft marked the same paragraph and commented, "Swift v. Tyson is too deeply embedded in our reports however one night differ from it were the question an open one." Willian Howard Taft, id. Taft also asked, "Why slould we adopt this prophecy or hope about the view of another Court?" Id.

286. Black \& White Taxicab, 276 U.S. at 523, 526; see also Palmer Transfer Co. v. Anderson, 115 S.W. 182, 187 (Ky. 1909) (holding that a railroad may not grant exclusive use of a certain part of its grounds to a single common carrier); McConnell v. Pedigo, 18 S.W. 15, 15-16 (Ky. 1892) (holding that imder Kentucky law a railroad could not grant to one carrier the exclusive right to come on depot grounds to transport railroad passengers to their final destinations). 
tive taxicab company in federal district court in Kentucky. Because federal common law would enforce monopolistic contracts, the coinpany won a decree preventing any interference with its exclusive privileges.

The Supreme Court, in an opinion by Butler, upheld this disposition of the case. It took the occasion to proclaim a ringing endorsement of the federal common law:

For the discovery of common law principles applicable in any case, investigation is not limited to the decisions of the courts of the State in which the controversy arises. State and federal courts go to the same sources for evidence of the existing applicable rule. The effort of both is to ascertain that rule.... As respects the rule of decision to be followed by federal courts, distinction has always been made between statutes of a State and the decisions of its courts on questions of general law. The applicable rule sustained by many decisions of this Court is that in determining questions of general law, the federal courts, while mclining to follow the decisions of the courts of the State in which the controversy arises, are free to exercise their own independent judgment. ${ }^{257}$

It is noteworthy that Butler's defense of federal common law explicitly turns on the notion that the common law can be assigned to neither state nor federal spheres of sovereignty. The "sources" of the common law were understood to be deeper than such artificial structural distinctions.

Holmes wrote a brilliant dissent, ${ }^{258}$ contending that federal recourse to general law constituted "an unconstitutional assumption of

287. Black \& White Taxicab, 276 U.S. at 529-30. "Outraging opponents of diversity and embarrassing its supporters, the Taxicab case quickly became a symbol of corporate exploitation of federal jurisdiction." EDWARD A. PURCELI, JR., BRANDEIS AND THE PROGRESSIVE CONSTITUTION: ERIE, THE JUDICIAL POWER, AND THE POLITICS OF THE FEDERAL COURTS IN TWENTIETH-CENTURY AMERICA 78 (2000).

288. Holmes's dissent was joined by Brandeis and Stone. Brandeis wrote Holmes, "The gem of the Term. I'm a joiner." Louis D. Brandeis, Annotation to Circulated Draft Opinion in Black \& White Taxicab \& Transfer Co. v. Brown \& Yellow Taxicab \& Transfer Co., Holmes Papers, supra note 68. Frankfurter later called the opinion "the term's masterpiece." HoLMES AND FRANKFURTER: THEIR CORRESPONDENCE, supra note 70, at 233. Stone wrote Holmes, "It seems to me shocking that we should allow our jurisdiction to be used to have set aside a well settled local policy like this." Letter from Harlan Fiske Stone to Oliver Wendell Holmes (Apr. 2,1928 ), Stone Papers, supra note 68. The case was argued on January 13, 1928; according to Stoue's docket book, McReynolds had voted at conference on January 21 to dissent alongside of Holmes, Brandeis, and Stone. About a month after the case was argued, Holmes wrote Frederick Pollock:

[T] here have been two cases on which I have got excited .... It is a time-honored practice for the U.S. judges when a case between citizens of different states is tried 
powers by the courts of the United States which no lapse of time or respectable array of opinion should make us hesitate to correct."289 Holmes argued that there was no "transcendental body of law outside of any particular State but obligatory within it unless and until changed by statute." "290 Building upon his positivist jurisprudence, he explained that law "does not exist without some definite authority behind it," 291 and that "the common law so far as it is enforced in a State... is not the common law generally but the law of that State

\begin{abstract}
before them and the question is one that depends, according to the common phrase, on "the general law," to say that the parties are entitled to their independent opinion, and, if so minded, to decline to follow the Supreme Court of the State. I say that this is a pure usurpation founded on a subtle fallacy. They say the question is a question of the common law and that they must decide what the common law is. I hit at this once in a dissent by saying that the common law is not a brooding omnipresence in the sky. [S. Pac. Co. v. Jensen, 244 U.S. 205, 222 (1917).] The question of what is the law of Massachusetts or of Louisiana is a matter that Mass. or La. has a right to determine for itself, and that being so, the voice of the state should be obeyed as well when its speaks through its Supreme Court as it would if it spoke through its Legislature. It all comes from Story in Swift v. Tyson who declined to follow New York law upon a commercial question.... The decision was unjustifiable in theory but did no great harm when confined to what Story dealt with, but under the infiuence of Bradley, Harlan, et al. it now has assumed the form that upon questions of the general law the U.S. courts must decide for themselves-of course expressing a desire to follow the state courts if they can. I doubt if I can carry a majority, for the tradition is old, and soine ex-circuit judges will not have forgotten the arrogant assumption to which they have been accustomed.
\end{abstract}

HOLMES-POLLOCK LETTERS, supra note 81, at 214-15. Pollock replied that "[t]he Kentucky judgment is in English eyes, antediluvian, but that does not matter." Id. at 219. We have a letter from Stone to Herman Ohphant, stating, "I think Holmes' dissent in the Black \& White Taxi case is a very reinarkable document. Solnetime I should like to tell you some of the circumstances attending its production. It must seem very heretical to some of our Harvard friends." Letter from Harlan Fiske Stone to Herman Ohphant (Apr. 23, 1928), Stone Papers, supra note 68.

289. Black \& White Taxicab, 276 U.S. at 533 (Holmes, J., dissenting). In the Nation, Heywood Broun immediately recognized the states' rights imphications of Holnes's position:

[I] $t$ is largely througl the seizure of authority that the Supreme Court has done its bit to sweep away the noxious theory of States' rights. I suppose the justices have done as inuch as ever Uinon soldiers did to batter down the sovereignty of the particular units as opposed to the federal whole. By a curious quirk Justice Holines who himself bore arms in the conflict is now among the States'-riglts wing of the court upon certain occasions.

Heywood Broun, It Seems to Heywood Broun, NATion, Apr. 25, 1928, at 479, 479. For a defense of Swift that frankly rests on the theory that diversity jurisdiction carries with it the power of federal courts to inake substantive law, see Henry Schofield, Swift v. Tyson: Uniformity of Judge-Made State Law in State and Federal Courts, 4 ILL. L. REV. 533, 537- 41 (1910).

290. Black \& White Taxicab, 276 U.S. at 533 (Holnes, J., dissenting).

291. Id. As Holmes had written to Morris Cohen in 1919: "As long as law means force(and when it means anything else I don't care who makes it and will do as I damn choose)force means an army and this army will belong to the territorial club. Therefore the territorial club will have the last word ...." Letter from Oliver Wendell Holmes to Morris Cohen (Nov. 23, 1919), Holmes Papers, supra note 68, Reel 30. 
existing by the authority of that State without regard to what it may have been in England or anywhere else."292

[I] $t$ is a question of the authority by which certain particular acts, here the grant of exclusive privileges in a railroad station, are governed. In my opinion the authority and only authority is the State, and if that be so, the voice adopted by the State as its own should utter the last word. ${ }^{293}$

Holmes advocated that Swift be left "undisturbed," but that it should not be allowed to spread its "assumed dominion into new fields."

292 Black \& White Taxicab, 276 U.S. at 533-34 (Holmes, J., dissenting). Frankfurter wrote Holmes on April 14, 1928:

I have just read your dissent in the Black \& Whire Taxicab case and I'm all stirred with dehght. You have written, if I may say so, a landmark opinion. To think that it has taken a century to expose the fallacy of one of the most obstinate doctrines of your Court! And you have done it with such incluctable lucidity that only the pertinacity of error can explain persistence in it. ... I'm particularly aroused, because l've been delving a bit into Swift $v$. Tyson and its sequelae, and the more I study the applications of that doctrine the less respect I have for it. My betters tell me to revere Story, but I cannot escape a strong scepticism about his intellectual greatness, much as I admire his energy, and his powers of formulation, which gave substance to seattered materials.

HOLMES AND FRANKFURTER: THEIR CORRESPONDENCE, supra note 70, at 225. Holmes answered, "I hoped that you would share my views in the Taxicab case. It is the only one that has stirred ine much lately." Id. at 226.

293. Black \& White Taxicab Co., 276 U.S. at 535 (Holmes, J., dissenting).

294. Id. It should be noted that even during the Taft Court, Holmes had himself written a number of opinions explicating general federal common law. For example, he used the "dominion" assumed by that law to push his objectivist conception of torts in Unired Zine \& Chemical Co. v. Britt, 258 U.S. 268, 274-76 (1922), and Baltimore \& Ohio Railroad Co. v. Goodman, 275 U.S. 66, 69-70 (1927). In the latter case, issued only six months before Black \& White, Holmes had promulgated the strict rule that a driver of an automobile could not recover for being struck by a train at a crossing unless he had first exited from his car to inspect the tracks. Goodman, 275 U.S. at 70. This rule was so severe that the Court promptly modified it in Pokora v. Wabash Railway Co., 292 U.S. 98, 105-06 (1934). In fact, Goodman also prompted a congressional bill decreeing that

in all causes of action arising from accidents occurring at or on any grade crossing over a street, road, or highway ... no rule shall be adopted or laid down by the Federal court of the United States contrary to the law of the State, Territory, or place where such accident occurred....

H.R. 7901, 70th Cong. (1927). The bill was introduced by a member of Congress from Ohio, whose constituent wrote Senator George Norris asking for his support of the legislation:

This restrictive bill was introduced by Mr. Murphy by reason of a recent U.S. Supreme Court ruling... in the case of Goodinan .... This opinion was rendered by Justice Holmes a venerable gentlemen, [sic] whom I an told is in the neighborhood of eighty-three years of age. I further understand that he does not ride in an automobile bnt is driven around in a horse drawn conveyance. Since we are living in the twentieth century ... it seems to the writer that the U.S. Supreme Court has adopted a very harsh rule. In other words a Railroad Company may operate it's [sic] trains over a public crossing at a reckless and unlawful rate of speed and if one should be struck at 


\section{Black \& White sparked a fierce controversy, ${ }^{295}$ but what is per- haps most remarkable and yet infrequently noticed about the opinion}

such crossing one is barred of recovery unless one has complied with the silly rule of stop, look and listen, and even get out of the automobile and go upon the track and then return to the automobile and drive over and upon the railroad crossing.

Letter from G. Jay Clark to George W. Norris (Dec. 27, 1927), George W. Norris Papers, Library of Congress, Washington, D.C. [hereinafter Norris Papers]. Senator Norris wrote back to Clark that he was not familiar with the case, but "if I had my way about it, I would take away from the Federal courts, jurisdiction in all such cases.... In fact, I have gone so far as to advocate the abolition of all Federal courts except the Supreme Court ...." Letter from George W. Norris to G. Jay Clark (Jan. 2, 1928), Norris Papers, supra. For Taft's observations concerning Holmes's "one horse coupe," see Letter from Williain Howard Taft to Helen Taft (May 4, 1924), Taft Papers, supra note 104, Reel 28:

Every Saturday froin Conference for sometime past I have brought Holmes and Brandeis hoine im iny car. Holmes has a one horse coupe but apparently Mrs. Holmes uses the coupe Saturday afternoon for soine purpose or else the coachman is given freedom that afternoon, because they are dependent on him. I am glad to furnish thein transportation.

295. On April 21, 1928, about two weeks after the decision, Brandeis wrote to Frankfurter:

1 .... I think it would be an excellent idea to draft a bill to correct the alleged rule acted on as to general law in the Black \& White case. The draft bill should go to Sen. Tom Walsh. He sat through the reading of the opinions, seated in a front seat, \& seeined much interested.

2. Another bill should be drawn, correcting the court's error in construction of the Fed Statutes as to what is a fraud on its jurisdiction. Such action as was taken in the Black \& White Case, ought to be prohibited whether strictly a fraud or not. That bill sliould go to Judge Moore.

3. Another bill should be drafted to put an end to removals, where there is a several controversy. That provision is being construed as removing the whole cause-an obvious injustice to those defendants who want to remain in the State Court, \& to the $\mathrm{pl}[$ ainti]ff. That bill also should go to Judge Moore.

BRANDEIS-FRANKFURTER LETTERS, supra note 148, at 330. On May 3, Senator Walsh introduced S. 4333, 70th Cong. (1928), which provided "[t] hat the decisions of the highest court of a State shall govern the courts of the United States in the ascertainment of the common law or general jurisprudence of such State." Id,; see also S. 96, 71st Cong. (1929) (sanc); PURCELL, sIlpra note 287, at 224-25 (detailing the end of the federal common law with the Erie decision in 1938); Letter from Henry Taft to Williain Howard Taft (May 15, 1928), Taft Papers, supra note 104, Reel 302:

I suppose you have also heard of the bill introduced by Walsh which compels the fed. eral courts to adopt the coinmon law or general jurisprudence of a state as laid down by the highest court of such state. This is to ineet the situation created by the court in the Black and White Taxicab case, decided April 9, 1928.

The controversy came at a particularly awkward time, for a bill sponsored by Norris and supported by Walsh to deprive federal district courts of both diversity and fcderal question jurisdiction had just passed the Senate Judiciary Committec. See S. 3151, 70th Cong. (1928); Limiting the Jurisdiction of District Courts of the United States, S. REP. No. 625 (1928). Taft regarded the bill as "a great attack on the admimistration of justice in this country." Letter from Williain Howard Taft to George Wickersham (Mar. 29, 1928), Taft Papers, supra note 104, Reel 300.

I think the question ought to be brought to the attention of the publie through the newspapers. The western States don't realize the value to them of having Fcderal Courts to which eastern capital nray recur for the adjustment of the rights of its own- 


\title{
is the inanner in which the Court interpreted federal common law to reflect the same preoccupations as the Court's substantive due pro-
}

\begin{abstract}
ers. The necessary effect of such legislation in requiring cvery person in the East who lends any money in the West to subject himself to the delays and injustices against non-residents in litigation in the West will certainly increase the cost of borrowing money in the West and send up the rates of interest. For those people who are interested in helping the farmer to redeem his mortgages, this is the worst thing that could happen.... I think the American Bar Association might well act on the subject, though its influence is not so great, but I think you might well in a deft way bring the attention of the New York press to the radical nature of this Bill.... [T] is a most Bolshevik body, and the House is the only one that retains any conservatism at all.... I think if you conld you might stir up members of your Bar representing the great lending element of the country to an agitation on this subject, just to have it understood what the purpose and effect will be.
\end{abstract}

Id.; see also Editorial, An Unwise and Dangerous Measure, 14 A.B.A. J. 266 (1928); Report of the Standing Committee on Jurispntdence and Law Reform, in REPORT OF THE FIFTY-FIRST ANNUAL MEETING OF THE AMERICAN BAR ASSOCIATION 425 (1928) (deseribing the bill as "probably the boldest and most radical attack upon the federal courts that lias been made in recent years").

To Casper Yost, the editor of the influential St. Louis Daily Globe-Democrat, Taft wrote that, "It is to me a very great shock that such a proposition could receive the approval of the Judiciary Committee of the Senate." Letter from Williain Howard Taft to Casper Yost (Apr. 5, 1928), Taft Papers, supra note 104, Reel 301. Diversity jurisdiction, Taft said, has been

the source of the greatest usefulness in avoiding injustice duc to sectional prejudice in the administration of justice. Such litigation las made up a large part of the dockets of the existing trial Federal courts, and always has ... engendered financial confidence on the part of the States where capital comes from in the justice to be rendered in other States to which the capital goes. If this bill were to pass, I should think it would strike the worst blow against the farmers that could be imagined.... Thoughtless people have not appreciated low cheap money has been sceured for all the enterprises through the West because of the jurisdiction of the trial Federal courts in these diverse citizenship questions.... The bill was devised by Senator Norris of Nebraska. He was once a local Circuit Judge in that State, and he told me that he was very mncli opposed to removals from his Court to the Federal Courts by nonresidents, and that lie intended to remedy that. He is supported in this by Senator Thomas Walsh, a great deal of whose practice has been in damage cases which were removed to the Federal Court for diverse citizenship.

Id. For Yost's subsequent editorial, see Editorial, Federal Courts in Peril, ST. LOUIS DAILY GLOBE-DEMOCRAT, Apr. 10, 1928, at 18:

That this would strike a blow to prosperity cannot be doubted. The investment of capital throughout the country is based upon confidence and that confidence depends very largely upon the assurance of inpartial justice. The flow of capital beyond state lines would be impeded by the risks of litigation where local or sectional or oceupational interests or prejudices inight influences courts or juries; and, if capital were widely distributed, where it would be subject to the differing laws and differing interpretations of state courts. All business that goes across state boundaries would be impeded by the risks of credit where forced collections would depend upon local decisions.

On May 3, 1928, Senator Norris amended his bill to reinstate federal question jurisdiction, but he remained adamant that diversity jurisdietion should be eliminated. S. 3151, 70th Cong. (May 3, Calendar Day May 8, 1928). Senator Norris specifically pointed to the Black \& White Taxicab case in defending his bill. Letter from George W. Nomis to Lewis A. Gannett (Apr. 28, 1928), Taft Papers, supra note 104, Reel 301. 
cess jurisprudence. Thus Butler specifically justified the federal rule upholding monopolistic contracts on the ground that:

Care is to be observed lest the doctrine that a contract is void as against public policy be unreasonably extended. Detriment to the public interest is not be presumed in the absence of showing that something improper is done or contemplated.... And it is to be remembered, as stated by Sir George Jessel, M. R., in Printing Company v. Sampson, L. R. 19 Eq. 462, 465, that public policy requires that competent persons "shall have the utinost liberty of contracting, and that their contracts, when entered into fairly and voluntarily shall be held sacred, and shall be enforced by Courts of justice." The station grounds belong to the railroad company and it lawfully may put them into any use that does not interfere with its duties as a common carrier. ${ }^{296}$

This passage bears direct comparison to the Taft Court's signature substantive due process decision, Adkins v. Children's Hospital, ${ }^{297}$

296. Black \& White Taxicab \& Transfer Co. v. Brown \& Yellow Taxicab \& Transfer Co., 276 U.S. 518, 528 (1928).

297. 261 U.S. 525 (1923). Sutherland wrote the opinion for a majority of five Justices. Id. at 539. Holmes dissented, id. at 567 (Holmes, J., dissenting), as did Taft (joined by Sanford), idl. at 562 (Taft, C.J., dissenting). Brandeis recused himself from participating in the case. Id. There exists a note from Taft to Holmes on the latter's dissent:

I fehicitate you on your dissenting opinion in the minimum wage case. It is very strong. I thank you, too, for the array of authorities. I feel as if I ought to say something on the subject. It will not be long. You have relieved me of much, but there are two or three things I would like to say. I have been wondering if we were not going to receive a recirculated opinion from Sutherland after the more careful Van Devanter has gotten in his handiwork to modify some of the extreme statements of the opinion, notably the resuscitation of the Loclmer case and the somewhat garish reference to the effect of the nineteenth amendment in changing the nature of women.

Letter from William Howard Taft to Ohver Wendell Holmes (Apr. 4, 1923), Holmes Papers, supra note 68, Reel 71. Holmes wrote Laski that "[t]he C.J. and Sanford seemed to think I said soinething dangerous or too broad so they dissented separately.... I think that what I said was plain common sense. It was intended inter alia to dethrone Liberty of Contract from its ascendancy in the Liberty business." HOLMES-LASKI LETTERS, supra note 153, at 495. Taft later remarked that "In the minimum wage case, I think some of my brethren went too far .... I think there are expressions in Sutherland's opinion that will merely return to plague us." Letter from William Howard Taft to John Hessin Clarke (May 3, 1923), Taft Papers, stupra note 104, Reel 253. Van Devanter, however, took the opposite view. "In many ways I have been fairly pleased with the court's work, more so than with that of two or three years. However, the narrow vote by which a sane doctrine prevailed in the Women's Minimum Wage case aclmonishes onc that he should not be too optimistic." Letter from Willis Van Devanter to Jolm C. Pollock (Apr. 25, 1923), Van Devanter Papers, supra note 116 . Sutherland appeared bhthely unconcerned with public criticism of his opinion, attributing it to the question of whose "toes are trod on." George Sutherland, Address, in 20 STATE B. AsS'N UTAH PROCEEDINGS 55, 66 (1924). 


\section{which struck down a federal statute establishing a minimum wage for women: $:^{298}$}

That the right to contract about one's affairs is a part of the liberty of the individual protected by [the due process clause of the Fifth

298. For a general review of press reaction, see Woman's Right to Low Wages, LrreRARY D1G., Apr. 21, 1923, at 12. The decision was intensely controversial and mobilized opponents of judicial review, some of whom would authorize Congress to reenact federal statutes constitutionally invalidated by the Court, and some of whom would prolibit the Court from striking down congressional legislation without the concurrence of at least seven Justices. See Robert L. Hale, Judicial Power and Judicial Social Theories, 9 A.B.A. J. 810, 810-11 (1923) (providing a summary of contemporary criticism of the Supreme Court); Editorial, A One-Man Constitution, N.Y. WORLD, Apr. 12, 1923, at 10; Borah Wants Mininum Wage Left to States, N.Y. TRIB., Apr. 11, 1923, at 2; Samuel Gompers, Take Away Its Usurped Power, 30 AM. FEDERATIONIST 399, 401 (1923) (urging enactment of "a constitutional amendment, finally and forcver restoring the law making power to the people through their representatives and taking from the Supreme Court the power to write such ugly pages as this into the history of a great democratic civilization"); High Court Scored; Usurps Its Power, GARMENT WORKER, May 25, 1923, at 3 (detailing criticism of the Supreme Court's annulment of the minimum wage law by women's trade unions); Labor Leaders Hit Wage Law Decision: Gompers and Woll Suggest Supreme Court Usurps Other Departments' Functions, N.Y. TIMES, May 16, 1923, at 21 (noting that labor leaders criticized wage law decisions); The Legal Right to Starve, NEw REPUBLIC, May 2, 1923, at 254, 255 ("Senator Borah's resolution if incorporated into the Constitution and limited to the Fifth and Fourtecnth Amendments .... would have avoided those strains upon the authority of, and confidence in, the Court which have been inore serious than it ought to be called on to bear. We submit that the most practicable, and nost conservative, discussion will be along that line."); Wage Act Voiding Stirs Demand for Majority Decision; Borah Would Require Supreme Court Vote of 7 to 9 to Set Aside Established Laws; Other Senators Propose Changes in Practice; La Follette Would Give Congress Power to Pass Measures in Adverse Decisions, N.Y. WoRL.D, Apr. 11, 1923, at 2:

Senator Borah is right when he insists that " $a$ law which has the approval of both the other departments of the Government as being constitutional ought not to be held void upon a mere 5 to 4 decision, or ought not to turn upon a single view or the opinion of one Judge." On this point public sentiment is rapidly becoming unamimous.

The Minimum Wage-Future Steps, NATION, May 9, 1923, 535, 535-36:

The only road to a compulsory minimum wage lies through amendment of our Federal Constitution, and inuch as we regret the alteration of that instrument in order to validate particular laws we think the present situation justifies it and are glad to leam that Governor Hart of Washington is calling a conference of the chicf executives of other States to determine a procedure.... In order to invalidate a law of Congress Senator Fess proposes that a two-thirds vote of the Supreme Court be required. Senator Borah wants agreement among at least seven of the nine judges, while Representative Frear asks a unanimous decision. Senator La Follette would give Congress the power to overrule the Supreme Court by repassing a law after an adverse decision. None of these schemes gets to the root of the evil, but one or another of them may be the best we can get as a transitional step. Somehow we must restrict our courts to judicial functions.

The Supreme Court Supplants Congress, NATION, Apr. 25, 1923, at 484, 485 ("Until this power of judicial veto is limited or eliminated, the people of the United States will neither be wholly free nor will they have the opportunity to test the vital principles of government of, for, and by the people."). For a good summary of the inany efforts to limit judicial review, see WILLIAM G. ROSS, A MUTED FURY: POPULISTS, PROGRESSIVES, AND LABOR UNIONS CONFRONT THE COURT, 1890-1937 (1994). 
Amendment]... is no longer open to question.... There is, of course, no such thing as absolute freedom of contract.... But freedoin of contract is, nevertheless, the general rule and restraint the exception; and the exercise of legislative authority to abridge it can be justified only by the existence of exceptional circumstances. ${ }^{299}$

It is clear that Black \& White and Adkins announce parallel visions of essential property and contractual rights. This is not accidental. The Taft Court understood due process rights to be deeply rooted in the common law. ${ }^{300}$ The classic statement is Meyer v. Nebraska:

The problem for our determination is whether the statute as construed and applied unreasonably infringes the liberty guaranteed to the plaintiff in error by the Fourteenth Amendment. "No State shall... deprive any person of life, hberty, or property, without due process of law."

While this Court has not atteinpted to define with exactness the liberty thus guaranteed, the term has received much consideration and some of the included things have been definitely stated. Without doubt, it denotes not merely freedom from bodily restraint but also the right of the individual to contract, to engage in any of the common occupations of life, to acquire useful knowledge, to marry, establish a home and bring up children, to worship God according to the dictates of his own conscience, and generally to enjoy those privileges long recognized at common law as essential to the orderly pursuit of happiness by free men. ${ }^{301}$

The Court's interpretation of due process was said to follow the "common law rule ... by which each individual was given independence in his action, so long as that independence did not infringe the independence of another."

What is less obvious is that Adkins, like Black \& White, also advances a structural agenda, because in explicating the Due Process Clause the Court understood itself to be articulating "the fundamen-

299. Adkins, 261 U.S. at 545-46; see also Chas. Wolff Packing Co. v. Court of Indus. Relations, 262 U.S. 522, 534 (1923) ("Freedom is the general rule, and restraint the exception. The legislative authority to abridge can be justified only by exceptional circumstances.").

300. For a full discussion, see Post, supra note 10, at 1537-39.

301. 262 U.S. 390,399 (1923) (emphasis added).

302. William Howard Taft, The Social Importance of Proper Standards for Admission to the Bar, in REPORT OF THE THIRTY-SIXTH ANNUAL MEETING OF THE AMERICAN BAR Association 931 (1913). For Taft's explanation of how constitutional rights of due process evolved from the social norms protected by the common law, see supra note 226. 
tal principles of liberty and justice which he at the base of all our civil and political institutions" 303 and which "are applicable alike in all the States and do not depend upon or vary with local legislation." ${ }^{304}$ Thus a major criticisin of Adkins was that it would impress a deadly uniformity on the States, rendering "invalid... any State minimum wage law which might come before the Court.."305 The Taft Court's robust expansion of pre-war Lochnerism ${ }^{306}$ would eventually provoke Thomas Reed Powell to protest that "[f]or one interested in local self government the work of the Supreme Court of the United States in applying the Fourteenth Amendment to state legislation must raise the question whether judicial centralization is not pushed to an extreme under our federal system. $"$ "307

Federal common law and federal constitutional rights were equally policies of "judicial centralization.",

303. Herbert v. Louisiana, 272 U.S. 312, 316 (1926).

304. Id. at 317.

305. The Minimum Wage Law Unconstitutional, 133 OUrLoOK 694, 694 (1923); see also John A. Ryan, A Deplorable Court Decision, CATH. Charmes REv., May 1923, at 170, 172 ("It should be remembered that all of the twelve minimum wage statutes in that many states are certain to be annulled as soon as actions can be brought against them in the various federal district courts ...."); The Minimum Wage, LA FOLLETIE's MAG., May 1923, at 68 (arguing that the decision undercut hard-won reforms).

306. For a discussion of the Taft Court's revival of Lochnerism, see Post, supra note 10, at 1492-93. It was contemporaneously noted that the Supreme Court was "particularly active since the World War in striking down legislation, both state and federal." Felix Frankfurter, The Silpreme Court and the Public, 83 Forum 329, 333 (1930). "Symbolizing the decade's pro-business orientation, the Taft Court invalidated state and federal regulatory laws im greater numbers and more frequently than any previous Court. Consistently, it favored the interests of private business, appeared sharply hostile to the cause of organized labor, and reasserted the doctrine of hiberty of contract to void regulatory statutes." PURCELL, supra note 287, at 21-22.

307. Thomas Reed Powell, The Supreme Court and State Police Power, 1922-1930, 17 VA. L. REV. 529, 531 (1931).

308. The remarkable decisions of the European Court of Justice are a vivid contemporary illustration of how a jurisprudence of rights can have highly centralizing effects. See, e.g., Jochen Abr. Frowein et al., The Protection of Fundamental Human Rights as a Vehicle of Integration, in INTEGRATION THROUGH LAW: EUROPE AND THE AMIERICAN FEDERAL EXPERIENCE, vol. 1, bk. 3, at 231 (Mauro Cappelletti et al. eds., 1986). The Framers of the Fourteenth Amendinent were quite aware of its centralizing effects. Consider, for example, Senator Charies Sumner's paean to the "imperialism of Equal Rights":

The Nation will not enter the State, except for the safe-guard of rights national in character, and then only as the sunshine, with beneficent power, and, like the sunshine, for the equal good of all. As well assail the sun because it is central-because it is imperial. Here is a just centralism; here is a generous imperialism. Shunning with patriotic care that injurious centralism and that fatal imperialism, which have been the Nemesis of France, I hail that other centralism which supplies an cqual protection to every citizen, and that other imperialism which makes Equal Rights the supreme 
not only in content, but also in structural implications. ${ }^{309}$ Each constituted an effort uniformly to protect what the Court regarded as essential rights. Each thoroughly intertwined structure and a substantive account of necessary human freedoms. ${ }^{310}$ Despite the strenuous protests of Holmes and Brandeis, ${ }^{311}$ the Court's pursuit of these policies was largely unchecked by countervailing considerations of local selfgovernment.

The Court's failure to conceptualize judicial centralization as an issue of federahism is highly significant, because it suggests that the Court imagined itself as transcending the dichotomy between federal and state spheres of sovereignty. When articulating general common law, the Court claimed the authority to express the deepest experiences and ideals of the whole American people. The Court summoned an analogous authority when articulating constitutional law. In its structural jurisprudence, the Court could limit congressional power by evoking the "public morals"312 of the entire country; in its

law, to be maintained by the national arm in all parts of the land. Centralisml Imperialism! Give me the centralism of Liberty. Give me the imperialism of Equal Rights.

44 CONG. Globe, 42nd Cong., 1st Sess. 651 (1871).

309. "The expanding scope and shiftmg orientation of the federal common law roughly paralleled the rise of substantive due process in the $1890 \mathrm{~s}$, and both developments expanded the role and lawmaking power of the federal judiciary." PURCELL, stupra note 148, at 61-62.

310. The Court did not abandon its commitment to use general law to protect the property rights it regarded as necessary for the uational market until 1938 in Erie Railroad Co. v. Tomp. kins, 304 U.S. 64 (1938), when it simultaneously ended its efforts to employ the Due Process Clause to offer constitutional protection to property rights. That was also the period when the Court abandoned its efforts to restrict comprehensive congressional oversight of the national market in the name of dual sovereignty. In the end, therefore, power was not redistributed back to the states, but instead shifted from an appointed federal judiciary to a democratically accountable Congress. The great transformation of the New Deal was from this perspective less a transfer of power from states to the federal government, than it was a reallocation of power from one branch of the federal government to another.

311. On Brandeis's unhappiness with the doctrine of federal common law, see PURCELL, supra note $287,133-40$. On his unhappimess with the federalism implications of substantive due process, see New State Ice Co. v. Liebmann, 285 U.S. 262, 311 (1932) (Brandeis, J., dissenting):

It is one of the happy imcidents of the federal system that a single courageous State may, if its citizens choose, serve as a laboratory; and try novel social and economic experiments without risk to the rest of the country. This Court has the power to prevent an experiment.... We have power to do this, because the due process clause has been held by the Court applicable to matters of substantive law as well as to matters of procedure.

For an example of the intersection between Holmes's theoretical opposition to substantivo due process and his localisin, see New York, Philadelphia \& Norfolk Telegraph Co. v. Dolan, 265 U.S. 96, 98 (1924) (opining that when a state court characterizes a statute as a matter having many purely local elements, the Supreme Court should be slow to disagree, even though it is not technically bound by the decision below).

312. See supra notes 223-36 and accompanying text. 
jurisprudence of substantive due process, the Court could establish individual rights that were substantially equivalent to common law rights which were grounded in neither state nor federal law. ${ }^{313}$ In such inatters the Court was apparently beyond the logic of federalisin altogether, because its mandate was to conserve "the general welfare, material and inoral," of the "one people" who inhabited the United States of America. ${ }^{314}$

\section{FEDERALISM AND THE DORMANT COMMERCE ClAUSE}

The federalism jurisprudence of the Taft Court thus presents a coinplex picture of intense but cross-cutting commitments. The doctrine of intergovernmental tax immunity was designed to distinguish and separate spheres of federal and state sovereignty, yet the Court's dedication to a uniform national market, sustained by uniform property and commercial law, was relentlessly nationalizing. The Court's apprehension of congressional power veered jaggedly between the implacable nationalism of its railroad cases and the dual sovereignty of its child labor decisions. The Court never conceived its own interventions as an issue of federalisin, even though the judicial centralization that resulted froin the Court's creation of constitutional and common law rights was an important factor in the distribution of power between the federal government and the states. The result was inconsistency and aunbiguity.

No area of the Taft Court's constitutional doctrine more fully reflects this confusion than its jurisprudence of the dormant Commerce Clause. Addressed to the precise intersection of local pohice power and the national inarket, the Court's dormant Commerce Clause decisions were caught between a fierce allegiance to dual sovereignty and a passionate commitment to market nationahism. They were also influenced by the Court's belief in the economic liberties it deemed necessary for the welfare of the nation. The decisions formed a major strand of the Taft Court's federalism jurisprudence. ${ }^{315}$ Even by 1922 it was said that one of the "marked tendencies" of the new Taft Court

313. See supra note 226; supra notes 295-309 and accompanying text.

314. Hoke \& Economides v. United States, 227 U.S. 308, 322 (1913).

315. Between the 1921 and 1928 Terms, the Court delivered some ninety-three opinions considering challenges to state regulations under the dormant Commerce Clause. The regulations were upheld in forty-five decisions and struck down in forty-eight decisions. See BERNARD C. GAVTT, THE COMMERCE ClaUSE OF THE UNITED STATES CONSTITUTION 541-56 (1932) (compiling cases in which state regulations were challenged). 
was "the expansion of restriction on state legislation alleged to interfere with the due freedom of interstate commerce."

\section{A. The Dormant Commerce Clause and Dual Sovereignty}

The overarching goal of dormant Commerce Clause doctrine is to protect interstate commerce froin balkanizing local regulations that impair the free interstate flow of goods and capital. "By the Constitution," the Court announced,

the power to regulate interstate commerce is expressly committed to Congress and therefore impliedly forbidden to the States. The purpose in this is to protect commercial intercourse from invidious restraints, to prevent interference through conflicting or hostile state laws and to insure uniformity in regulation.... [I]n the matter of interstate commerce we are a single nation-one and the same people. $^{317}$

316. Powell, supra note 134, at 497.

317. Pennsylvania v. West Virginia, 262 U.S. 553, 596 (1923). Although Van Devanter's rhetoric in Pennsylvania $v$. West Virginia deliberately echoes Marshall's general pronounceinents in Cohens v. Virginia, 19 U.S. (6 Wheat) 264, 413 (1821), Van Devanter's stress on "uniformity in regulation" articulates an important post-Reconstruction theme within the Court's dormant Commerce Clause jurisprudence. See, e.g., United States v. E.C. Knight Co., 156 U.S. 1,32 (1895) (Harlan, J., dissenting) ("Commerce among the States, as this court has declared, is a unit, and in respect of that commerce this is one country, and we are one people."); Bowman v. Chi. \& Northwestern Ry. Co., 125 U.S. 465, 508 (1888) (commenting that one of the great objects of the Constitution was to secure uniformity of commercial regulations); W. Union Tel. Co. v. Pendleton, 122 U.S. 347, 358 (1887) (affirming the supreme authority of Congress over the subject of commerce by telegraph with foreign countries or among the states); Robbins v. Shelby County Taxing Dist., 120 U.S. 489, 494 (1887) ("[I]n the matter of interstate commerce the United States are but one country, and are and must be subject to one system of regulations and not to a multitude of systems."); Walling v. Michigan, 116 U.S. 446, $456-57$ (1886):

[Congressional] non-action [with regard to] the transportation, purchase, sale, and exchange of commodities [between states] is a declaration of its purpose that the commerce in that commodity... shall be free. There would otherwise be no security against conflicting regulations of different states, each discriminating in favor of its own products or citizens and against the products and citizens of other states.

Mobile v. Kimball, 102 U.S. 691,697 (1880) ("[I]t is a matter of public history that the ob. ject of vesting in Congress the power to regulate commerce with foreign nations and anrong the States was to insure uniformity of regulation against conflicting and discriminating State legislation."); Inman S.S. Co. v. Tinker, 94 U.S. 238, 245 (1876) (explaining that commerce clauses were intended to secure harmony and uniformity in regulation). Of course the Court's decisions after Reconstruction also evimced a contrapuntal theme that recognized the inevitability of state regulations of interstate commerce and that sought to distinguish between regulations directly and indirectly affecting that commerce. See infra notes $357-77$ and accompanying text. 


\section{The framework of dual sovereignty impelled the Court to distinguish a sphere of national uniformity, ${ }^{318}$ comprised of interstate commerce,}

318. Taft had articulated the constitutional justification for national uniformity in the regulation of interstate commerce when as president he vetoed the Webb-Kenyon Act, Pub. L No. 62-398, 37 Stat. 699 (1913), which prohibited the shipment of liquor into any state where it was intended to be used in a manner illegal under state law:

One of the main purposes of the union of the States under the Constitution was to relieve the commerce between the States of the burdens which local State jealousies and purposes had in the past imposed upon it; and the interstate-commerce clause in the Constitution was one of the chief reasons for its adoption. The power was there conferred upon Congress. Now, if to the discretion of Congress is committed the question whether in interstate commerce we shall return to the old methods prevailing before the Constitution or not, it would seein to be conferring upon Congress the power to amend the Constitution by ignoring or striking out one of its most important provisions. It was certainly intended by that clause to secure uniformity in the regulation of commerce between the States. To suspend that purpose and to permit the States to exercise their old authority before they became States, to interfere with commerce between them and their neighbors, is to defeat the constitutional purpose.

49 CONG. REC. 4292 (1913). It is worth noting that then-Senator George Sutherland also beheved that the Act was unconstitutional, arguing that

[s]ince the purpose of conferring authority to regulate interstate commerce upon Congress was to prevent a inultiplicity of diverse and conflicting rules made by the separate States, it would seem to follow that the regulation of any given article must be uniform in character, and that varying regulations could not be justified upon the varying desires or opimions of the several States.

Id. at 2910 (statement of Sen. Sutherland). Senator Sutherland observed that as a direct consequence of the Court's decisions holding that insurance was not commerce, see supra note 243 and accompanying text, "[m]any of the States have... passed laws in elfect discriminating against insurance companies of sister States and in favor of their own." Id. at 2905 (statement of Sen. Sutherland).

Despite Taft's veto, the Webb-Kenyon Act was made law, and, although the Court had previously held that state prohibitions on the importation of liquor violated the dormant Commerce Clause, Leisy v. Hardin, 135 U.S. 100, 124-25 (1890), it nevertheless uplield the WebbKenyon Act in Clark Distilling Co. v. Western Maryland Railway Co., 242 U.S. 311, 337-38 (1917). For good discussions of the interplay between state and federal regulation, see Henry Wolf Bikle, The Silence of Congress, 41 HARV. L. REV. 200, 205-209 (1927) (suggesting that Congress's affirmative indication that interstate commerce may be subject to state restrictions may allow such restrictions even in areas of national concem); Barry Cushman, Lochner, Liquor and Longshoremen: A Puzzle in Progressive Era Federalism, 32 J. MAR. L. \& CoM. 1, 21-35 (2001). Cushman accurately observes that the Taft Court in its admiralty jurisprudence adopted poticies that were inconsistent with Clark Distilling. Id. The lierce nationalism of the Taft Court is evident in the vigorous commitunent to national imiformity displayed in admiralty decisions like Washington v. W.C. Dawson \& Co., 264 U.S. 219 (1924), which struck down federal legislation authorizing state workmen's compensation laws to apply to injured scamen. Over a masterful dissent by Brandeis, id. at 227 (Brandeis, J., dissenting), the Court held, per McReynolds, that:

Without doubt Congress has power to alter, amend or revise the maritime law by statutes of general application embodying its will and judgment. This power, we think, would permit enactunent of a general employers' hability law or general provisions for compensating injured employees; but it may not be delegated to the several States. The grant of admiralty and maritime jurisdiction looks to uniformity; otherwise wide discretion is left to Congress.... Exercising another power-to regulate 
from a discrete and separate realm of intrastate commerce, which was deemed the proper arena for local self-government.

Taft Court decisions often imagined imterstate commerce as a distinct and objective entity, so that economic transactions could be assigned to either interstate or intrastate commerce on the basis of actual physical characteristics of the world. In Heisler v. Thomas Collier Co. ${ }^{319}$ for example, the Court was faced with a dormant Counmerce Clause challenge to a Pennsylvania tax on anthracite coal. ${ }^{320}$ Because Pennsylvania had a virtual monopoly on anthracite and shipped eighty percent of its production out-of-state, ${ }^{321}$ the tax would almost certainly be paid by out-of-state consumers. The Court, however, was neither noved by this fact, nor by the fact that the tax was imposed upon anthracite that was imtended for interstate shipment and that may even have already been purchased by out-of-state customers.

commerce-Congress has prescribed the liability of interstate carriers by railroad for damages to employees ... and thereby abrogated conflicting local rules. ... .

This cause presents a situation where there was no attempt to prescribe general rules. On the contrary, the manifest purpose was to permit any State to alter the maritime law and thereby imtroduce conflicting requirements. To prevent this result the Constitution adopted the law of the sea as the measure of maritime rights and obligations. The confusion and difficulty, if vessels were compelled to comply with the local statutes at every port, are not difficult to see. Of course, some within the States may prefer local rules; but the Umion was formed with the very definite design of freeing maritime commerce from imtolerable restrictions incident to such control. The subject is national. Local imterest must yield to the common welfare. The Constitution is supreme.

Id. at 227-28. Dawson carried forward the jurisprudence of such controversial decisions as Southern Pacific Co. v. Jensen, 244 U.S. 205, 215 (1917), and Knickerbocker Ice Co. v. Stewart, 253 U.S. 149, 163-64 (1920).

319. 260 U.S. 245 (1922).

320. The tax was for $1.5 \%$ of the market value of the anthracite, assessed "at the time when the coal lias been subjected to ... preparation "and is ready for shipment or inarket." Itl. at 253.

321. As the Court stated:

Anthracite coal... is asserted to be found in only nine counties in [Pennsylvania], and practically nowhere else in the United States. The fact, it is further said, gives the State a nonopoly of it, and that a tax upon it is levymg a tribute upon the consumption of other States, and nine of thein have appeared by their attorneys general to assail it as illegal and denounce it as an attempt to regulate interstate commerce. In emphasis of the contention, the Governor of the State is quoted as urging the tax because of that effect. The fact, tribute upon the consumers of the coal in other States, is pronounced mevitable, as, it is the assertion, $80 \%$ of the total production is shipped to other States, and that this constitutes its "major 'niarket." And the dependency upon Pennsylvamia is represented as impossible of evasion or relicf. Anthracite coal, is the assertion, has become a prime necessity of those States, "particularly for domestic purposes" and even "municipal laws and ordinances have been passed forbidding the use of other coal for leating purposes."

Id. at 258. 
Instead, the Court held that the Pennsylvania tax was constitutionally legitimate because it was assessed before the coal had actually entered interstate commerce, when it was still "part of the general mass of property of the State, and subject to its jurisdiction. ${ }^{\text {, }}$ It was therefore within the state's sphere of power. Any other rule, the Court said, would have unacceptable consequences:

If the possibility, or, indeed, certainty of exportation of a product or article from a State determines it to be in interstate commerce before the commenceinent of its moveinent from the State, it would seem to follow that it is in such commerce from the instant of its growth or production, and in the case of coals, as they lie in the ground. The result would be curious. It would nationalize all industries, it would nationalize and withdraw from state jurisdiction and dehiver to federal commercial control the fruits of California and the South, the wheat of the West and its meats, the cotton of the South, the shoes of Massachusetts and the woolen industries of other States, at the very inception of their production or growth, that is, the fruits unpicked, the cotton and wheat ungathered, hides and flesh of cattle yet "on the hoof," wool yet unshorn, and coal yet unmined, because they are in varying percentages destined for and surely to be exported to States other than those of their production. 323

The Court held that dormant Commerce Clause questions were to be decided strictly on the basis of whether state regulations apphied to interstate or to intrastate commerce. The effect of state regulation on interstate commerce was not constitutionally relevant. A contrary conclusion, the Court reasoned, would "nationalize all industries" and hence deprive states of the capacity for the local self-government required by dual sovereignty. ${ }^{324}$

322 Id. at 261; see also Lacoste v. Dep't of Conservation, 263 U.S. 545, 550-51 (1924) (upholding Louisiana's right to regulate the taking of its wild animals and their subsequent use).

323. Heisler, 260 U.S. at 259-60.

324. See Hammer v. Dagenhart, 247 U.S. 251, 272-73 (1918):

[T] he production of articles, intended for interstate commerce, is a matter of local regulation. When the commerce begins is determined, not by the character of the commodity, nor by the intention of the owner to transfer it to another state for sale, nor by his preparation of it for transportation, but by its actual delivery to a common carrier for transportation, or the actual commencement of its transfer to another state.... If it were otherwise, all manufacture intended for interstate shipment would be brought under federal control to the practical exclusion of the authority of States.... 
Heisler sought to protect state prerogatives by imagining the boundary between mtrastate and interstate commerce as a precise frontier, which was the point at which goods began their interstate journey. "[T] ${ }^{325}$ "Tere inust be a point of time," the Court noted, when goods

cease to be governed exclusively by the domestic law and begin to be governed and protected by the national law of commercial regulation, and that moment seems to us to be a legitimate one for this purpose, im which they commence their final movement for transportation from the State of their origin to that of their destination. ${ }^{326}$

The function of dormant Commerce Clause jurisprudence was neither to weigh competing state and national interests, nor to assess the effects of state regulations on interstate commerce, but instead to chart the location of this real and physical boundary. ${ }^{327}$ State regulations that reached beyond this boundary were flatly unconstitutional.

325. See, e.g., Carson Petroleum Co. v. Vial, 279 U.S. 95, 101 (1929) (stating that the "crucial question ... in determining whether personal property is subject to local taxation is that of its continuity of transit"); Hughes Bros. Timber Co. v. Minnesota, 272 U.S. 469, 475 (1926) ("Mere intention ... does not put [goods] in interstate commerce, nor does preparatory gathering, for that purpose, at a depot. It inust appear that the moveinent for another State has actually begun and is going on."); Champlain Realty Co. v. Brattleboro, 260 U.S. 366, 376 (1922):

The interstate commerce clause... does not give immunity to movable property from local taxation which is not discriminative unless it is in actual continuous transit in interstate commerce. When it is shipped by a common carrier from one state to another, in the course of such an uninterrupted journey, it is clearly immunc. The doubt arises when there are interruptions in the joumey, and when the property, in its transportation, is under the complete control of the owner during the passage. If the interruptions are only to promote the safe or convenient transit, then the continuity of the interstate trip is not broken.

See supra note 323 and accoinpanying text.

326. Heisler, 260 U.S. at $260-61$.

327. The Taft Court was frequently called upon to decide exactly when goods had begun their interstate journey "froin the place of their production or preparation," Heisler, 260 U.S. at 259 , and this task could sometimes take on surprisingly netaphysical dimensions. In Oliver Iron Mining Co. v. Lord, 262 U.S. 172 (1923), for exaniple, the Court upheld a Minnesota tax on mining as applied to an open pit where the ore was loaded "directly into" railroad cars that promptly began their "interstate journey." Id. at 178. The Court refused to acknowledge any ambiguity in the boundary between interstate and intrastate commerce.

Mining is not interstate commerce, but, like manufacturing, is a local business subject to local regulation and taxation. Its character in this regard is intrinsic, is not affected by the intended use or disposal of the product, is not controlled by contractual engagenients, and persists even though the business be conducted in close connection with interstate commerce. The ore does not enter interstate commerce until after the mining is done, and the tax is imposed only in respect of the mining.... The tax may mdirectly and incidentally affect such commerce, just as any taxation of railroad and telegraph lines does, but this is not a forbidden burden or interference.

Id. at 178-79 (citations omitted). 
"The action of the State as a regulation of interstate coinmerce does not depend upon the degree of interference; it is illegal in any degree." ${ }^{328}$

Heisler presents a relatively simple picture of donnant Commerce Clause doctrine, for it turns questions of constitutional structure entirely on whether state regulations are imposed on interstate or on imtrastate commerce. This framing of the question, however, puts considerable stress on differentiating between interstate and intrastate commerce, a task that could often prove highly problematic. Consider, for example, Missouri ex rel. Barrett v. Kansas Natural Gas Co., ${ }^{329}$ which imvolved the efforts of state public utilities commissions to regulate the prices charged by an interstate supplier of natural gas to local distributors. The gas flowed in a continuous stream from the site of its production to its ultimate consumers, traversing in its journey the pipelines of various intermediary companies. The Court concluded that the boundary between interstate and intrastate commerce ought to be placed at the point at which title to the gas passed from the interstate supphier to local distributors:

With the delivery of the gas to the distributing companies... the interstate movement ends. Its subsequent sale and delivery by these companies to their customers at retail is intrastate business and subject to state regulation. In such case the effect on interstate commerce, if there be any, is imdirect and incidental. But the sale and delivery here is an inseparable part of a transaction in interstate commerce-not local but essentially national in character,-and enforcement of a selling price in such a transaction places a direct burden upon such commerce inconsistent with that freedom of interstate trade which it was the purpose of the commerce clause to secure and preserve. It is as though the Commission stood at the state line and imposed its regulation upon the final step in the process at the moment the interstate commodity entered the State and before it had become part of the general mass of property therein. ${ }^{30}$

328. Heisler, 260 U.S. at 259. The Court also held that "whether any statute or action of a State impinges upon interstate commerce depends upon the statute or action, not upon ... the motive which impelled it." Id.

329. 265 U.S. 298 (1924).

330. Id. at 308 (citation omitted). In Sonneborn Bros. v. Cureton, 262 U.S. 506 (1923), by contrast, the Court found that goods shipped into a state could be taxed only after their "interstate transportation was at an end," by which it meant that the goods had "come to a state of rest" and were indistinguishable from other goods within the state. Id. at 508 . 
As in Heisler, the Court essentially assumed that the constitutionality of state regulation depended upon whether it applied to interstate or to intrastate commerce. The Court was therefore forced to define a sharp distinction between the two, which it accomplished by imagining the transfer of the gas to local distributors as a virtual boundary that fundamentally altered the constitutional character of the gas. State regulation was permitted on one side of the boundary, but not on the other, even if Congress had not in fact "seen fit to regulate. "331 In such circumstances, Congress's

silence, where it has the sole power to speak, is equivalent to a declaration that that particular commerce shall be free from regulation.... [H]ere the sale of gas is in wholesale quantities, not to consumers, but to distributing companies for resale to consumers in numerous cities and communities in different States. The transportation, sale and delivery constitute an unbroken chain, fundamentally interstate from beginning to end, and of such continuity as to anount to an established course of business. The paramount interest is not local but national, admitting of and requiring uniformity of regulation. Such uniformity, even though it be the uniformity of governinental nonaction, may be highly necessary to preserve equality of opportunity and treatınent ainong the various communities and States concerned. ${ }^{332}$

As in Heisler, the Court's opinion reflected the intellectual influence of dual sovereiguty. It postulated a sharp boundary between intrastate and interstate commerce that absolutely partitioned state froin federal power. The challenge of the case was to ascertain the location of this boundary. For Heisler the dividing line was marked by the physical movement of goods. But the Court in Kansas Natural Gas Co. could not use this criterion, for natural gas was in continuous motion. How, then, might the distinction between interstate and intrastate commerce be determined? The Court sought to solve the problem by shiding toward an imagery of "interests," which Heisler

331. Kansas Natural Gas Co., 265 U.S. at 308.

332. Id. at 308-10. The Court also concluded that

[t]he business of supplying, on demand, local consumers is a local business, even though the gas be brought from another State and drawn for distribution directly from interstate inains; and this is so whether the local distribution be made by the trausporting company or by independent distributing coinpamies. Iu such case the local imterest is paramount, and the interference with interstate commerce, if any, indirect and of minor inportance.

Id. at 309. 
had not employed. The Court explained that the transfer of the gas to local distributors was the constitutionally decisive moment because it marked the point where the "paramount interest" shifted froin the "national" to the "local." 333

The difficulty, however, is that the language of "interests" does not fit easily with the perspective of dual sovereignty. It is not plausible to expect that either federal or state "interests" simply disappear at some sharp boundary. Governments have reasons for regulating goods that do not suddenly vanish merely because goods have begun, or ceased, an interstate journey. Governmental interests are in fact persistent and continuous, with extension and weight, and they are therefore awkward material for justifying the abrupt and discontinuous transitions required by an effort to construct separate and exclusive spheres of state and federal sovereignty.

This misunatch explains why the Court in Kansas Natural Gas Co. made no effort to explicate why the paramount interests of federal and state governments reversed at precisely the point at which gas was transferred to local distributors. Indeed, it is at first blush highly implausible to conclude that a theoretical "uniformity of governmental nonaction" ${ }^{\text {334 }}$ represents a greater governmental interest than concrete and palpable state interests in the local price of natural gas. The Court was manifestly uninterested in carefully examining this question. It was instead content to allow its evaluation of government interests to remain formal and abstract. As a consequence, the language of "interests," which was originally adduced to explain and justify the location of the boundary between state and federal power, in the end served only as a conclusory proxy for the necessity of locating some precise constitutional distinction between state and federal sovereignty.

\section{B. Dual Sovereignty and the Boundary Between Interstate and Intrastate Commerce}

Kansas Natural Gas Co. is in this sense a transitional and confused decision; it attempts to use the modern language of "interests" to rationalize the traditional perspective of dual sovereiguty. This represents a significant (if understandable) failure of judicial craft. The fundamental difficulty, however, was deeper than the absence of

333. Id.

334. Id at 310 . 
an adequate conceptual apparatus to locate the boundary between interstate and intrastate commerce. The essential problem was that the very idea of separate and exclusive domains of federal and state sovereignty was fast becommg untenable. The Court's own decisions expanding the reach of congressional commerce power explicitly recognized the interpenetration of interstate and intrastate commerce.

In decisions like Stafford and Olsen, the Court stressed that the legal definition of interstate commerce must reflect "practical" " concerns. The very image of a "stream" of commerce was meant to indicate that local and national economic transactions could be so intermingled as to fuse into a single "unit" that frustrated all efforts to pry them apart. That is why Olsen could simultaneously hold that the grain traded at the Chicago Board could properly be subject to "local taxing ... while in Chicago," and yet that this did "not take it out of interstate commerce in such a way as to deprive Congress of the power to regulate it." ${ }^{336}$ Olsen thus flatly denied the existence of metaphysically distinct and exclusive spheres of interstate and intrastate commerce.

The Court was, however, frequently willing to formulate its dormant Commerce Clause doctrine as though such spheres actually existed. In Public Utilities Commission v. Attleboro Steam \& Electric Co. ${ }^{337}$ for example, the Court confronted a case in which a local Rhode Island power utility, the Narragansett Company, was charging such low rates to a Massachusetts corporation, the Attleboro Company, that it was endangering its own fimancial health. The Rhode Island Public Utilities Commission sought to raise the rates, arguing that it could not

effectively exercise its power to regulate the rates for electricity furnished by the Narragansett Company to local consumers, without also regulating the rates for the other service which it furnishes; that

335. See FTC v. Pac. States Paper Trade Ass'n., 273 U.S. 52, 63-64 (1927) ("Commerce among the States is not a technical legal conception, but a practical one, drawn from the course of business."); Stafford v. Wallace, 258 U.S. 495, 518-19 (1922) (same); stupra note 183. The Court would repeat this point even in the context of the dormant Commerce Clause. See, e.g., Foster-Fountain Packing Co. v. Haydel, 278 U.S. 1, 10 (1928) ("In determining what is interstate commerce, courts look to practical considerations and the established course of business."); Eureka Pipe Line Co. v. Hallanan, 257 U.S. 265, 272 (1921) ("As has been repeated many times, interstate commerce is a practical conception ....").

336. 262 U.S. at 33; see also Bimderup v. Pathe Exch., Inc., 263 U.S. 291, 311 (1923) ("It docs not follow that because a thing is subject to state taxation it is also immune from federal regulntion under the Commerce Clause.").

337. 273 U.S. 83 (1927). 
if the Narragansett Company continues to furnish electricity to Attleboro Company at a loss this will tend to increase the burden on the local consumers and impair the ability of the Narragansett Company to give them good service at reasonable prices; and that, therefore, the order of the Commission prescribing a reasonable rate for the interstate service to the Attleboro Company should be sustained as being essentially a local regulation, necessary to the protection of matters of local interest, and affecting interstate commerce only indirectly and incidentally. ${ }^{338}$

This argument is exactly analogous to that advanced to support the Transportation Act of 1920 . Federal regulation of intrastate railroad rates was authorized on the theory that the national governinent had a legitimate interest in ensuring that railroads received sufficiently high revenues froin intrastate rates as to inaintain the health of the interstate rail system. The Rhode Island Public Utilities Coinmission similarly contended that it should be authorized to regulate interstate sales to ensure that unduly low interstate rates did not endanger the provision of adequate intrastate service. The Court, however, refused to accept the analogy. ${ }^{339}$ "The test of the validity of a state regulation," it said, "is not the character of the general business of the company, but whether the particular business which is regulated is essentially local or national in character."

Plainly, however, the paramount interest in the interstate business carried on between the two companies is not local to either State, but is essentially national in character. The rate is therefore not subject to regulation by either of the two States in the guise of protection to their respective local interests; but, if such regulation is required it can only be attanied by the exercise of the power vested in Congress. ${ }^{340}$

As in Kansas Natural Gas Co., the Court in Attleboro Steam \& Electric Co. sought to marry the language of "interests" to the perspective of dual sovereignty. In both cases, however, the language of "interests" failed to provide any analytic force. At root Attleboro Steam \& Electric Co. expressed the premise of dual sovereignty that state and federal spheres of authority should be kept rigorously sepa-

338. Id. at 87.

339. Brandeis authored a solo dissent, which Holmes refused to join, commenting, "I don't see it." Oliver Wendell Holmes, Annotation to Circulated Draft Opinion in Public Utilities Commission v. Attleboro Steam \& Electric Co., Brandeis Papers, supra note 116.

340. Attleboro Steam \& Elec Co., 273 U.S. at 90. 
rated. The reasoning of Attleboro Steam \& Electric Co. would thus have stopped the Transportation Act of 1920 dead in its tracks. The assumption that government "interests" fall neatly along the boundary between interstate and intrastate commerce would necessarily have implied tlat states retained a "paramount interest" over intrastate railroad rates and that the ICC was therefore disabled from setting sucl rates.

If Attleboro Steam \& Electric Co. is coinpared to the Taft Court's decisions enforcing the Transportation Act of 1920, it seems clear that there were circumstances in which the Taft Court was willing to conclude that the interdependence of interstate and intrastate commerce could justify national power over intrastate commerce, but not state autliority over interstate commerce. The highly nationalist tilt of the Taft Court is evident in this asymmetry. ${ }^{341}$ As the Court becane increasingly sensitive to the reach and scope of interstate commerce, its dormant commerce clause doctrine became correspondingly more hostile to state regulation, creating in the process an ever-expanding "uniformity of governmental nonaction." 342 There is no small irony in the fact that this powerfully nationalizing jurisprudence was underwritten by the intellectual framework of dual sovereignty, which, as Bailey and Heisler indicate, had traditionally been associated with the cause of states' rights.

I slould stress that the Court could have decided in Attleboro Steam \& Electric Co. on a rationale that was compatible with its treatment of congressional authority. If Rhode Island were empowered to raise Narragansett's rates, Massachusetts imight equally be authorized to lower them; the imterstate transmission of power might thus have become subject to mcompatible state regulations. ${ }^{343}$ Uni-

341. Peter Fish has observed that "Taft, Willis Van Devanter, Pierce Butler, George Sutherland, and Edward T. Sanford constituted a majority bloc decidedly antagonistie to exereises of state authority." Peter G. Fisl, William Howard Taft and Charles Evans Hughes: Conservative Politicians as Chief Judicial Reformers, 1975 SuP. CT. REv. 123, 135. Writing in 1933, Felix Frankfurter and Henry M. Hart, Jr. thought they detected a trend toward decreasing interference with state court judgments, a weakening in the impulse to invoke federal law to invalidate state legislative and administrative action. Just as this impulse was rampant, both in bar and bench, in the prosperous years of the middle twenties, so it may be, in these times of economic dislocation, relativcly quiescent.

Felix Frankfurter \& Henry M. Hart, Jr., The Business of the Stupreme Court at October Term, 1932, 47 HARV. L. REV. 245, 274 (1933) (citations omitted).

342. See supra note 332 and accompanying text.

343. See, e.g., Attleboro Steam \& Elec. Co., 273 U.S. at 90; 
form congressional authority to regulate intrastate commerce did not create a similar potential for internal inconsistency. It is significant, therefore, that the Court in Attleboro Steam \& Electric Co. did not rest its conclusion on the possibility of such incompatible regulation. Instead it flatly asserted the "essentially national" character of interstate commerce, and it held that this character rendered interstate commerce immune from regulation "in the guise of protection to... local interests. ${ }^{2344}$

This sharp focus on the exclusive national character of interstate commerce led the Court to strike down numerous state laws that did not carry the potential for inconsistent state regulations. In DahnkeWalker Milling Co. v. Bondurant, ${ }^{3+5}$ for example, the Court considered the apphication of a Kentucky statute "prescribing the conditions on which corporations of other States might do business" to the purchase of wheat in Kentucky to be dehvered "on board the cars of a common carrier" for shipinent to Tennessee. ${ }^{346}$ The Court ruled that the application of the statute was constitutionally invalid, although there was no possibility of inconsistent state regulations. The Court held simply that a "corporation of one state may go into another, without obtaining the leave or license of the latter, for all the legitimate purposes of [interstate] commerce; and any statute of the latter state which obstructs or lays a burden on the exercise of this privilege is void under the commerce clause. $\$ 347$

Furthermore, if Rhode Island could place a direct burden upon the interstate business of the Narragansett Company because this would result in indirect benefit to the customers of the Narragansett Company in Rhode Island, Massachusetts could, by parity of reasoning, reduce the rates on such interstate business in order to benefit the customers of the Attleboro Company in that State, who would have, in the aggregate, an interest in the interstate rate correlative to that of the customers of the Narragansett Company in Rhode Island.

344. Id.

345. 257 U.S. 282 (1921).

346. Id. at 286.

347. Id at 291. The Court held that "[w]here goods are purchased in one state for transportation to another the commerce includes the purchase quite as inuch as it does the transportation." Id. at 290. This account of interstate commerce is in tension with the view of interstate commerce taken in Heisler, for in that case the coal had already been purchased for interstate delivery. Edward Corwin thus characterized the holding of Bondurant as

[a] new extension to the "commerce" clause as a restriction on state power ... [ [ ] is an important development of the law, as the later application of it, in Lemke v. Farmers' Grain Co. [258 U.S. 50 (1922)], to set aside a vital part of North Dakota's plan for controlling the marketing of grain in the interest of the growers, strikingly demonstrates.

Corwin, supra note 135, at 630-31. Conwin concluded that "this new extension of the "commerce' clause probably takes away from the states much more valuable 'sovereignty' than the 
Similarly, in Real Silk Hosiery Mills v. Portland ${ }^{348}$ the Court unanimously struck down as applied to a foreign corporation a nondiscriminatory ordinance requiring any salesinan who takes "orders for goods for future delivery and receives payment ... in advance" to "secure a license and file a bond." nance materially burdens interstate coinmerce and conflicts with the Conimerce Clause.... Nor can we accept the theory that an expressed purpose to prevent possible frauds is enough to justify legislation which really imterferes with the free flow of legitimate interstate conımerce.",350

In Texas Transport \& Terminal Co. v. New Orleans $^{351}$ the Court struck down the application of a nondiscriminatory license tax as applied to a steamship agent who exclusively represented steamship compamies engaged in interstate or foreign commerce. The Court relied upon

the general and well established rule, which is that a state or state municipality is powerless to impose a tax upon persons for selling or seeking to sell the goods of a nonresident within the state prior to their introduction therein ... or to impose a tax upon persons for securing or seeking to secure the transportation of freight or passengers in interstate or foreign commerce.

\section{Direct and Indirect Burdens on Interstate Commerce}

The Court's holding in Texas Transport \& Terminal Co. was too much for Brandeis, who, along with Holmes, dissented. ${ }^{353}$ Observing that it was black-letter law that the property of interstate railroads could be taxed, ${ }^{354}$ Brandeis noted that imterstate and intrastate com-

Child Labor decision saves to them; and this is done by judicial interpretation alone." $I d$. at 631 n.85. Brandeis dissented in Bondurant on jurisdictional grounds. 257 U.S. at 293 (Brandeis, J., dissenting).

348. 268 U.S. 325 (1925).

349. Id. at 335 .

350. Id. at 335-36.

351. 264 U.S. 150 (1924).

352. Id. at $152-53$.

353. Id. at 155 (Brandeis, J., dissenting). Butler's docket book indicates that at conference Sanford had voted with Brandeis and Holmes.

354. Id. at 156 (Brandeis, J., dissenting); see also St. Louis \& Southwestern Ry. Co. v. Nattin, 277 U.S. 157, 159 (1928) ("Without doubt a local legislative body .. . may lay general ad valorein taxes upon all property within its jurisdiction, including that of common carriers engaged in interstate commerce, without violating the Federal Constitution. That such taxation does not amount to regulation of interstate commerce is settled doctrine."); Citizens Nat'l Bank v. Durr, 
merce were far too intermingled for any such simple and blunt rule as the Court proposed. ${ }^{355}$ It was simply a fantasy to imagine that economic transactions could be neatly and cleanly classified into interstate commerce, in which national interests predominated, and intrastate commerce, in which local imterests held sway. ${ }^{3.6}$ Brandeis argued, therefore, that the proper question was not whether a state regulated interstate cominerce, but whether it improperly burdened that commerce. "The validity of a state tax under the commerce clause," he wrote, "does not depend upon its character or classification. It is not void merely because it affects or burdens interstate commerce. The tax is void only if it directly burdens such cominerce, or (where the burden is indirect) if the tax discriminates against or obstructs inter-

257 U.S. 99, 110 (1921) ("Ordinary property taxation imposed upon property employed in interstate commerce does not amount to an unconstitutional burden on the commerec itself.").

355. Brandeis argued:

It is settled law that interstate commerce is not directly burdened by a tax imposed upon property used exclusively in interstate commerce, Transportation Co. $v$. Wheeling, 99 U.S. 273, 284; Old Dominion S.S. Co. v. Virginia, 198 U.S. 299, 306; or by a tax upon net income derived exclusively froun interstate commerce, United States Glue Co. v. Oak Creek, 247 U.S. 321; Shaffer v. Carter, 252 U.S. 37, 57; compare Peck \& Co. v. Lowe, 247 U.S. 165; or by an occupation tax, fixed in amount, although the business consists exclusively of selling goods brought from another State. Wagner $v$. City of Covington, 251 U.S. 95. On the other hand, the burden is deemed direct, where the tax is upon property moving in interstate commerec, Champlain Realyy Co. v. Brattleboro, 260 U.S. 366; or where it lays, like a gross-receipts tax, a burden upon every transaction in such commerce "by withholding, for the use of the State, a part of every dollar received in such transactions," Crew Levick Co. v. Pennsylvania, 245 U.S. 292, 297; or where an occupation tax is laid upon one who, like a drummer or delivery agent, is engaged exclusively in inaugurating or completing his own or his employer's transaction in interstate commerce. Robbins v. Shelby County Taxing District, 120 U.S. 489; Davis v. Virginia, 236 U.S. 697.

The New Orleans tax is obviously not laid upon property moving in interstate commerce. Nor does it, like a gross-receipts tax, lay a burden upon every transaction. It is simply a tax upon one of the instrumentalities of interstate commerce. It is no more a direct burden, than is the tax on the other indispensable instrumentalities; upon the ship; upon the pilot boat, which slie must employ; upon the wharf at which she must load and unload; upon the office which the owner would have to hire for his employees, if, instead of engaging the services of an independent contractor, he laad preferred to perform those duties himself.

Tex. Transp. \& Terminal Co., 264 U.S. at 156-57 (Brandeis, J., dissenting).

356. In a letter to Frankfurter, Brandeis suggested that Frankfurter "start the Webb Kenyon idea as to Foreign Corp[oration]s," which would essentially involve congressional legislation authorizing local regulations of interstate commerce. BRANDEIS-FRANKFURTER LETTERS, sILpra note 148, at 202. Mentioning the Texas Transport \& Terminal Co. case by name, as well as other Taft Court decisions, Brandeis observed that "many more communities dismayed at amendment of their license fee taxation, would surely be glad to join \& with the Back to the State Movement on the rise, Congress imight do some work on these lines." Id. For Taft and Sutherland's views of "the Webb Kenyon idea," see supra note 318. 
state commerce." 357 Although this distinction between "direct" and "indirect" burdens sounds "strangely formal" deis, it was in fact a common trope in the doctrine of the dormant Commerce Clause. ${ }^{359}$ The metaphor sigmified that the imagined, immaculate separation between interstate and intrastate commerce, a separation toward which the dual sovereignty logic of cases like Heisler or Bondurant teleologically aspired, simply did not exist.

The doctrinal basis of Brandeis's analysis can be seen in the emerging Taft Court jurisprudence of automobiles. By the 1920s everyone understood that highways and vehicles were arteries of interstate commerce. But everyone also understood that states were primarily responsible for the regulation of highways and vehicles, so that it would be disastrous if the Court were to attempt to impose the "uniformity of governmental nonaction" $" 360$ that it willingly embraced in other contexts. For this reason, the Court very quickly came to the conclusion that "in the absence of federal legislation covering the subject, [a] State may impose, even upon vehicles using the highways exclusively in interstate commerce, non-discriminatory regulations for the purpose of insuring the public safety and convenience,, 361 and that "a state may impose, even on motor vehicles engaged exclusively in interstate commerce, a reasonable charge as their fair contribution to

357. Texas Transp. \& Terminal Co., 264 U.S. at 155 (Brandeis, J., dissenting).

358. BICKEL, supra note 103, at 118. Bickel notes that Brandeis nevertheless adhered "unfalteringly to the concept of direct and indirect burdens." Id.

359. The trope had a venerable history. See Austin v. Tennessee, 179 U.S. 343, 349 (1900) (upholding a Tennessee law prohibiting the importation and sale of cigarettes):

We have had repeated occasion to hold, where state legislation has been attacked as violative ... of the power of Congress over interstate commerce,... that, if the action of the state legislature were a bona fide exercise of its police power, and dictated by a genuine regard for the preservation of the public health or safety, such legislation would be respected, though it might interfere indirectly with interstate commerce.

Cushman, Formalism, supra note 205, at 1111-14.

360. See supra note 332 and accoinpanying text.

361. Sprout v. City of South Bend, 277 U.S. 163, 169 (1928). The Court observed that

[a] State may ... require payment of an occupation tax from one engaged in both intrastate and interstate commerce... . But in order that the fee or tax shall be valid, it must appear that it is inposed solely on account of the intrastate business; that the anount exacted is not increased because of the interstate business done; that one engaged exclusively in interstate commerce would not be subject to the iniposition; and that the person taxed could discontinue the intrastate business without withdrawing also from the interstate business.... The privilege of engaging in [interstate] commerce is one which a State cannot deny.... A State is equally inhibited from conditioning its exercise on the payment of an occupation tax.

Id. at 170-71 (citations omitted). 
the cost of constructing and maintaining the public highways." ${ }^{362}$ States could require motor vehicles "engaged exclusively in interstate commerce" to obtain liability imsurance, so long as the required insurance was "limited to damages suffered within the State by persons other than the passenger."363 They could impose maximum weight limits on trucks, even if these limits prevented interstate trucking firms from realizing a profit. ${ }^{364}$ States could not, however, extend or withdraw permission to engage in interstate commerce based upon judgments abont whether an interstate route "is already being adequately served" by other common carriers.

362 Id. at 170. In Clark v. Poor, 274 U.S. 554 (1927), an interstate trucking company challenged the application to it of an Ohio law that required motor transportation companies operating within the state to obtain a certificate and to pay a fee "graduated according to the number and capacity of the vehicles used." Id. at 555-56.

The plaintiffs claim that, as applied to them, the Act violates the commerce clause of the Federal Constitution. They insist that, as they are engaged cxelusively in interstate commerce, they are not subject to regulation by the State; that it is without power to require that before using its highways they apply for and obtain a certificate; and that it is also without power to impose, in addition to the annual license fec demanded of all persons using autonnobiles on the highways, a tax upon them ... for the maintenance and repair of the highways and for the administration and enforcement of the laws governing the use of the saine. The contrary is settled. The highways are public property. Users of them, although engaged exclusively in interstate counmerce, are subject to regulation by the State to ensure safety and convenience and the conservation of the higliways.

Id. at 556-57.

363. Sprout, 277 U.S. at 172.

364. Morris v. Duby, 274 U.S. 135, 144 (1927).

In the absence of national legislation especially covering the subject of interstate commerce, the State may rightly prescribe uniform regulations adapted to promote safety upon its highways and the conservation of their use, applicable alike to vehicles moving in interstate commerce and those of its own citizens. Of course the State may not discriminate against interstate commerce.

Id. at 143 (citations omitted).

365. Buck v. Kuykendall, 267 U.S. 307,313 (1925). In the context of the automobile cases, therefore, the Court flatly contradicted the assertion of Heisler that "[w]hether any statute or action of a State impinges upon iuterstate commerce depends upon the statute or action, not upon ... the motive which impelled it" Heisler, 260 U.S. at 259. McReynolds dissented in Buck, authoring an opinion that revealed his full commitnent to the logic of dual sovereignty and to its concomitant distinction between economic transactions that were essentially local and those that were essentially national:

The problems arising out of the sudden increase of motor vehicles present cxtraordinary difficulties. As yet nobody definitely knows what should be done. Manifestly, the exigency cannot be met through uniform rules laid down by Congress.

Interstate commerce has been greatly aided-amazingly facilitated, indeedthrough legislation and expenditures by the States. The challenged statutes do not discriminate against such commerce, do not seriously inpede it, and indicate an honest purpose to promote the best interests of all by preventing unnecessary destruction and keeping the ways flt for maximum service. 
The Taft Court's law of automobiles ultimately derived from a venerable line of cases, conventionally understood to originate with Cooley v. Board of Wardens, ${ }^{366}$ which held that certain matters intertwined with interstate commerce were so intrinsically local that states could regulate thein in the absence of preemptive congressional legislation. ${ }^{367}$ Cooley concerned a Pennsylvamia statute, explicitly approved by federal law, that regulated pilots in local harbors. Although concedimg that the statute reached interstate commerce, Cooley nevertheless squarely held that "the power to regulate commerce[] embraces a vast field, containing not only many, but exceedingly various subjects... some imperatively demanding a single uniforin rule... and some, hike the subject now in question, as imperatively demanding that diversity, which alone can meet the local necessities of navigation." ${ }^{368}$ In the absence of contrary federal legislation, state laws governing matters that were "local and not national," matters that did not "admit only of one uniform system," were constitutional, even though apphied to interstate commerce. ${ }^{369}$

The determination of which subjects of interstate commerce could be subject to local control, and which would "admit only of one uniform system," necessarily mvolved implicit conclusions of policy.

The Federal Government has not and cannot undertake precise regulations. Control by the States must continue, otherwise chaotic conditions will quickly develop. The problems are essentially local, and should be left with the local authorities unless and until something is done which really tends to obstruct the free flow of commercial intercourse.

The situation is similar to the one growing out of the necessity for harbor regulations. State statutes concerning pilotage, for example, have been upheld although they amounted to regulation of interstate and foreign commerce. "They fall within that class of powers which may be exercised by the States until Congress has secn fit to act upon the subject."

George M. Bush \& Sons Co. v. Maloy, 267 U.S. at 325-26 (McReynolds, J., dissenting) (quoting Olsen v. Smith, 195 U.S. 332, 341 (1904)); see also United States v. Hubbard, 266 U.S. 474, 480, 481 (1925) (McReynolds, J., dissenting) (concluding that states may control until Congress indicates its intent to regulate).

The Taft Court's automobile cases are analogous to its decisions dealing with intcrstate ferries. The Court was willing to grant states authority to "fix reasonable rates applicable to ferriage from [their] river front[s] or... prescribe reasonable regulations calculated to sccure safety and convemience in the conduct of the business," but it was not willing to grant states power to "make [their] consent and license a condition precedent to a right to engage" in interstate ferriage. Mayor of Vidaha v. McNeely, 274 U.S. 676, 683 (1927). The Court thus distinguished, as with highways, "power to hicense and therefore to exclude from the business" from "power to regulate it." Id. at 680.

366. 53 U.S. (12 How.) 299 (1851).

367. The cases are discussed in Cushman, Formalism, supra note 205, at 1114-16.

368. 53 U.S. (12 How.) at 319.

369. Id. 
The automobile cases reveal that in reaching these conclusions the Court evaluated many factors, including the balance between national and state interests in the context of particular transactions, the purposes and effects of specific state regulations, and so forth. ${ }^{300}$ The Court frequently used the distinction between direct and indirect effects on interstate commerce to express its conclusions about these issues. ${ }^{371}$ State actions that constituted "a real and direct invasion" of interstate commerce were said to be unconstitutional, whereas those whose effects on interstate commerce were "something incidental or remote" ${ }^{372}$ would withstand constitutional scrutiny. "The line of division between cases where, in the absence of congressional action, the State is authorized to act, and those where state action is precluded by mere force of the commerce clause of the Constitution," observed the Court, "is not always clearly marked."

In the absence of congressional legislation, a State may constitutionally impose taxes, enact inspection laws, quarantine laws and, generally, laws of internal police, although they may have an incidental effect upon interstate commerce.... But the commerce clause of the Constitution, of its own force, restrains the States from imposing direct burdens upon interstate commerce. ${ }^{374}$

370. For an explicit example outside the automobile context, see St. Lonis-S.F. Ry. Co. v. Pub. Serv. Comm'n, 261 U.S. 369 (1923), in which the Court was required to decide whether an order of the Missouri Public Service Commission requiring an interstate train 10 stop at a certain city violated the dormant Commerce Clause. The Court held that "the primary principle is that, although interstate commerce is outside of regulation by a State, there may be instances in which a State, in the exercise of a necessary power may affect that commerce. There is, however, no inevitable test of the instances; the facts in each must be considered." Id. at 371. The Court accordingly balanced the state's interests in ordering the stops against the resulting impact on interstate commerce. Id. at 372-73; cf. Lake Shore \& Mich. S. Ry. Co. v. Ohio ex rel. Lawrence, 173 U.S. 285, 308 (1899) (acknowledging the Court's adoption of a case-by-case inquiry and declining an "attempt to lay down any rule that would govern every conceivable case").

371. F.D.G. RIBBLE, STATE AND NATIONAL POWER OVER CONIMERCE 221 (1937).

372. United Leather Workers Int'l Union v. Herkert \& Meisel Trunk Co., 265 U.S. 457, 466 (1924).

373. Foster-Fountain Packing Co. v. Haydel, 278 U.S. 1, 10 (1928); Pub. Utils. Comm'n v. Attleboro Steam \& Elec. Co., 273 U.S. 83, 87-88 (1927); Interstate Busses Corp. v. Holyoke St. Ry. Co., 273 U.S. 45, 52 (1927); Shafer v. Fanners Grain Co., 268 U.S. 189, 199 (1925); Indus. Ass'n v. United States, 268 U.S. 64, 81-82 (1925); Buck v. Kuykendall, 267 U.S. 307,315 (1925); Hygrade Provision Co. v. Shernnan, 266 U.S. 497, 503 (1925); Sonneborn Bros. v. Cureton, 262 U.S. 506, 515 (1923); Lemke v. Farmers Grain Co., 258 U.S. 50, 59 (1922).

374. Missouri ex rel. Barrett v. Kan. Natural Gas Co., 265 U.S. 298, 307 (1924); see also Or.Wash. R.R. \& Navigation Co. v. Washington, 270 U.S. 87, 101 (1926):

In the relation of the States to the regulation of interstate commerce by Congress there are two fields. There is one in which the state can not interfere at all, even in the silence of Congress. In the other, (and this is the one in which the legitimate exercise 
The trope of "direct" burdens was thus a doctrinal response to the complexities of American social structure, which resisted any clean separation imto distinct and exclusive spheres of interstate and intrastate commerce. ${ }^{375}$ Deploying the trope required "considerations of policy"376 to determine whether particular regulations of interstate commerce were best left at the local level, or whether they ought instead to be governed by national standards. ${ }^{377}$ At issue was not only the weight of federal interests in uniformity, but also the force of state interests in proinoting local welfare. ${ }^{378}$ As Holmes reinarked for the

of the State's police power brings it into contact with interstate coinmerce so as to affect that commerce), the State may exercise its police power until Congress las by affirmative legislation occupied the field....

375. As the New Republic pointed out, the assumption that there was "an incompatibility between state and federal regulation," and the aspiration to carve out "mutually exclusive spheres of action for eacl,", will

not work in a highly organized society sucl as the United States of today. The two functions are really supplementary. The success of a federal systein depends upon an assignment of powers and responsibilities to the central and local governments which varies at different times in response to clianging conditions, but which always assumes coöperation rather tlian antagonism.

Anti-Federalism, supra note 31, at 212.

376. Thomas Reed Powell, Current Conflicts Between the Commerce Clatse and State Police Power, 1922-1927, 12 MINN. L. REv. 321, 323 (1928) (Part I of a three-part article).

377. See Cushman, Formalism, supra note 205, at 1101-26. Sonuetimes, the Court simply addressed these policy questions directly, without using the trope. In Ozark Pipe Line Corp. $v$. Monier, 266 U.S. 555 (1925), for example, the Court did not distinguish between direct and indirect burdens on interstate commerce, yet Sutherland explained for the Court that the question of whether Missouri could assess a frauchise tax aganist an interstate oil pipeline, in virtue of the various intrastate activities required to nuaintain and service the pipeline company, depended upon whether

the tax as a practical matter constitutes a burden upon interstate commerce... . If the business taxed is in fact separate local busimess, not so connected with interstate commerce as to render the tax a burden upon sucl commerce, the tax is good.... The protection against imposition of burdens upon interstate commerce is practical and substantial and extends to whatever is necessary to the complete enjoyment of the right protected.

Id. at $562-63,565$.

378. Thus, in a case in which natural gas was "transmitted directly from the source of supply in Pennsylvania to the consumers in the cities and towns of New York," without the intervention of any local distributors, the Court nevertheless decided that New York could regulate the local price of the gas, even though it was regulating interstate commerce, because

[i]n dealing with interstate commerce it is not in some instauces regarded as an infringement upon the authority delegated to Congress, to permit the States to pass laws indirectly affecting such commerce, when needed to protect or regulate matters of local interest. Such laws are operative until Congress acts under its superior authority by regulating the subject-matter for itself.

Pa. Gas Co. v. Pub. Serv. Comm'n, 252 U.S. 23, 28-29 (1920). The inconsistency betwcen the logic of Pennsylvania Gas Co., and that of Missouri v. Kansas Natural Gas Co, 265 U.S. 298 
Court in Gillespie, "It is well understood that a certain amount of reaction upon and interference with [interstate] commerce cannot be avoided if the States are to exist and inake laws." "379

The inetaphor of "direct" burdens was, however, a poor vehicle to convey the nature and weight of these competing considerations. The distinction between "direct" and "indirect" burdens was both opaque and conclusory. The actual policy conclusions driving particular decisions were rarely made explicit. The metaphor did not work well as doctrine because it failed to provide much useful guidance to state and lower federal courts or to government officials. The greatest potential for confusion, readily apparent in a case like Texas Transport \& Terminal Co., lay in the fierce tension between the metaphor and the urgent thrust of dual sovereignty radically to distinguish interstate froin intrastate commerce by forbidding all state regulation of interstate commerce. Decisions like Heisler were structured according to a logic and rhetoric that were simply inconsistent with the notion that states could regulate interstate commerce so long as they imposed only indirect burdens.

Taft Court decisions frequently sought to ameliorate this tension by interpreting the image of "direct" burdens in ways that were heavily influenced by the perspectives of dual sovereignty. Kansas Natural Gas Co. is a good example of this tendency. The adjective "direct" is deployed, but it appears to mean only that the state had attempted to regulate interstate commerce itself..$^{300}$ Another good example is $\mathrm{Hel}$ son $v$. Kentucky, ${ }^{381}$ in which the Court considered the application of Kentucky's general sales and use tax on gasoline to a ferryboat that was engaged in "an exclusively interstate business.",382 Although the tax was imposed only for the gasoline "actually consumed within the limits of Kentucky,"383 and although Kentucky could have taxed the value of the property of the ferryboat as "measured by its use or use value in interstate commerce," 356 the Court concluded that Kentucky was actually taxing the use of the ferryboat in interstate commerce. ${ }^{3 x}$

(1924), is a measure of the Taft Court's escalating commitunent to the priority of perceived national interests. See supra notes 329-34 and accompanying text.

379. Gillespie v. Oklahoma, 257 U.S. 501, 505 (1922).

380. See supra note 330 and accompanying text.

381. 279 U.S. 245 (1929).

382 Id. at 248.

383. Id.

384. Id. at 253 (Stone, J., concurring).

385. "While a state has power to tax property having a situs within its limits, whether employed in interstate commerce or not, it cannot interfere with interstate commerce through the 
"Is not the fuel consumed in propelling the boat an instrumentality of commerce no less than the boat itself? A tax, which falls directly upon the use of one of the means by which commerce is carried on, directly burdens that commerce." 386 Such a tax, Sutherland concluded for the Court, was unconstitutional because it trenched on the sphere "of interstate and foreign commerce" that was "committed exclusively to the control of Congress." ${ }^{387}$

Helson employs the inetaphor of a "direct" burden on interstate commerce as a transparent means to accomplish the same urgent ambition this Article identified in Panhandle, radically to disentangle national from state domains of authority. No doubt that is why Stone wrote separately in Helson to "acquiesce in the result," but to dissent from the Court's reasoning. ${ }^{388}$ He argued that he could not

find any practical justification for ... an interpretation of the commerce clause which would relieve those engaged in interstate commerce from their fair share of the expense of government of the states in which they operate by exempting them from the payment of a tax of general application, which is neither aimed at nor discriminates against interstate commerce. ${ }^{389}$

His critique was essentially the same as the one he had developed in Metcalf: Just as the federal governinent could not be insulated from the effects of general state taxation, so interstate commerce could not be insulated from the effects of general state regulations of intrastate commerce. Interstate and intrastate commerce were intermingled and interdependent, as were national and state interests, and no doctrine could be adequate that failed to acknowledge this fact.

Stone's most sustained critique of this aspect of the Court's dormant Commerce Clause jurisprudence was his famous dissent in $D i$ Santo v. Pennsylvania ${ }^{390}$ in which the Court struck down a law requiring non-steamship companies that sold steamship tickets to ob-

imposition of a tax which is, in effect, a tax for the privilege of transacting such commerce." Id. at 249.

386. Id. at 252.

387. Id. at 248.

388. Id. at 252 (Stone, J., concurring). Stone was joined by Holmes and Brandeis. Brandeis had written Stone, "I think the reasoning in Sutherland's opinion is, in view of the Court's decisions, worse than the result. Perhaps concurring in the result-with a few well chosen words would be the most effective blow for a right rule." Letter from Louis D. Brandeis to Harlan Fiske Stone (Apr. 4, 1929), Stone Papers, supra note 68. McReynolds dissented scparately without opimion.

389. Helson, 279 U.S. at 253 (Stone, J., concurring).

390. 273 U.S. 34 (1927). 
tain a license. The object of the law was to prevent fraud. The Court's opinion was blunt and abrupt, ${ }^{391}$ holding that the "soliciting of passengers and the sale of steamship tickets... constitute[s] a wellrecognized part of foreign commerce," and that a "state statute which by its necessary operation directly interferes with or burdens foreign commerce is a prohibited regulation and invalid, regardless of the purpose with which it was passed."392 Stone's dissent is celebrated for its frontal attack on the distinction between direct and indirect burdens on commerce:

In this case the traditional test of the limit of state action by inquiring whether the interference with commerce is direct or indirect seeins to me too mechanical, too uncertain in its application, and too remote from actualities, to be of value. In thus making use of the expressions, "direct" and "indirect interference" with commerce, we are doing little more than using labels to describe a result rather than any trustworthy formula by which it is reaclied. ${ }^{303}$

Althougl Stone's analysis of judicial craft is well taken, ${ }^{34}$ and although it sparked sustained and justified criticism of the Court's "formalistic jurisprudence,"395 it did not reflect Stone's deepest critique of the Court's dormant Commerce Clause doctrine.

391. With characteristic acerbity, Thomas Reed Powell noted that "[ $]$ ]or a reasoned consideration of the problem before the court we must go to the minority opinions." Thomas Reed Powell, Current Conflicts Between the Commerce Clause and State Police Power, 1922-1927, 12 MINN. L. REV. 470, 479 (1928) (Part II of a three-part article). Brandeis, joined by Holmes, dissented, arguing that the licensing requirement did not "directly burden interstate or foreign commerce" because it was "in essence an inspection law." Di Santo, 273 U.S. at 39, 41-42 (Brandeis, J., dissenting). Brandeis's opinion is notable for its famous plea: "[T]he logic of words should yield to the logic of realities." Id. at 43. Stone's separate dissent was joined by both Holmes and Brandeis.

392. Di Santo, 273 U.S. at 36-37. "The Congress has complete and paramount authority to regulate foreign commerce and, by appropriate measures, to protect the public against the frauds of those who sell these tickets and orders." Id. at 37.

393. Id. at 44 (Stone, J., dissenting).

394. Noel T. Dowling, Interstate Commerce and State Power, 27 VA. L. REV. 1, 27-28 (1940); see, e.g., Powell, supra uote 391, at 491:

The notable dissent of Mr. Justice Stone in the Di Santo Case should be pinned on the wall of the study of every Justice of the Supreme Court to serve as a guide in the writing of opinions even in cases where no one has any doubt that the interests of unimpeded commerce outweigh the local need for regulation. Unless the competing considerations which must have been voiced in the conference room are madc explicit in the opinions, counsel may not be forewamed of the factors that induce judgment and so may continue to write briefs and make arguments that exalt excessive gencralizations at the expense of concrete analysis.

395. Mechanical Jurisprudence and Constitutional Law, NATION, Mar. 9, 1927, at 253-54: 
The worst aspect of that doctrine was its tendency, exemplified in cases like Heisler or Bondurant, to decide cases based upon the primitive question of whether state regulation had trespassed onto the inviolable domain of interstate commerce. In the right hands, the distinction between direct and indirect burdens on interstate commerce could actually amehorate the harsh and arbitrary effects of this tendency. It provided a doctrinal category by which some state regulations of interstate commerce could be accommodated, which is no doubt why Brandeis refused to abandon the distinction. ${ }^{396}$ The Court was content to allow the distinction to remain opaque, ${ }^{397}$ however, because it was unable to decide exactly what relationship between state pohice power and interstate commerce it wished constitutionally to impose. It was unwilling exphicitly to endorse an alternative model to the traditional perspective of dual sovereignty, which would sharply distinguish federal from state spheres of power.

The deeper challenge of Stone's dissent, therefore, was addressed to the fundamental framework of dormant Commerce Clause doctrine. Just as in Metcalf Stone had sought to reorient intergovernmental tax immurity doctrine to the question of the actual effects of government taxation on governmental functioning, so in Di Santo he sought to reorient dormant Commerce Clause doctrine to "a consid-

\begin{abstract}
[Justice Stone deals] with his problem realistically, in the light of modern ideas of logic and of human reasoning, and abandons the formalistic jurisprudence witl which the majority apparently deceive theinselves. Whatever one may think of the presentday reluctance to concentrate additional power in the federal government, it seems clear that the inatter with which the State statutes deal can best be left for regulation by State officials rather than by remote government officials in Washington. Obvious also is it that in the present state of the public mind Congress will be unhikely to undertake federal regulation of the problem involved, and the sole practical effect of the decision will probably be to allow the defrauding of ignorant immigrants to go on unchecked. It is to be regretted that, perhaps because of a failure of some of its members to appreciate that they are in the last analysis dealing not with questions of pure logic but of policy, the majority of our highest judicial tribunal have once more shown an inability to grapple with the social reahities which he behind all legal rules.
\end{abstract}

396. See supra note 358 and accompanying text.

397. So, for example, in Buck v. Kuykendall, 267 U.S. 307 (1925), the Court held that a state could constitutionally regulate interstate traffic on its highways so long as it did so for a proper purpose. Id. at 314. Yet im other contexts the Court was prepared to aunounce that "a state statute which by its necessary operation directly imterferes with or burdens [interstate] commerce is a prohibited regulation and invalid, regardless of the purpose with which it was enacted." Shafer v. Farmers Gram Co., 268 U.S. 189, 199 (1925). But if the purpose of a state's regulation is part of the calculus of whether the burden it imposes on interstate commerce is "direct," it is exceedingly puzzling why the Court would also assert that a statute imposing a direct burden is unconstitutional "regardless of the purpose with which it was passed." Di Santo, 273 U.S. at 37. Clearly, then, the distimction between direct and indirect burdens on interstate commerce is doing different work im cases like Shafer and Di Santo than in cases like Buck. 
eration of all the facts and circumstances, such as the nature of the regulation, its function, the character of the business involved and the actual effect on the flow of commerce," claiming that only such comprehensive analysis could determine whether a "regulation concerns interests peculiarly local and does not infringe the national interest in maintaining the freedom of commerce across state lines."

Stone's observations reflect a thoroughly inodern appreciation of the consequences of abandoning the framework of dual sovereignty and of seriously pursuing the implications of a language of interests. Concluding that the mere partition of economic transactions into intrastate and interstate commerce was insufficient to decide cases, Stone imagined state and federal splieres of authority as constituted by interests that were overlapping and intermingled. This perspective virtually ruled out teleological approaclies, like dual sovereignty, that sought to implement a fully articulated model of the respective domains of state and federal power. Radically sidestepping the need for such a model, Stone instead proposed an approach that focused on judicial method; he enjoined courts candidly to consider all relevant circumstances and governmental interests, trusting that a sufficiently shared sense of relevant purposes and values would someliow produce correct, or at least satisfactory, decisions. We now call this approach "balancing," and Stone was the only member of the Taft Court squarely to face and accept its enormous implications.

398. 273 U.S. at 44 (Stone, J., dissenting). Fourteen years later, Stone would have the pleasure of authoring the opinion overruling Di Santo on exactly these grounds. California v. Thompson, 313 U.S. 109, 116 (1941).

399. In Stone's early years on the Court, however, his grasp of this new perspective was far from certain. In Kansas City Structural Steel Co. v. Arkansas, 269 U.S. 148 (1925), for example, Stone dissented (without opinion) from the holding of the Court that Arkansas could fine a corporate out-of-state construction firm for conducting business without a license because it had shipped to Arkansas material to be used in the construction of a bridge it had contracted to build within the state. Id. at 152. Exemplifying the perspective of dual sovcreignty, Stone srote Thomas Reed Powell that his dissent was based upon the view "that the test of whether or not the acts of the corporation went beyond [interstate] commerce should be purely objective." Letter from Harlan Fiske Stone to Thoinas Reed Powell (Mar. 3, 1926), Stone Papers, supra note 68. The problem, Stone explained in a letter to the opinion's author, Pierce Butler, was that the only "acts" done by the construction firm within Arkansas "before complying with the State law were the shipping of the merchandise into the state to its own order and its delivery there to the subcontractor. These acts, it wonld seem to me, do not constitute intrastate commerce...." Letter froin Harlan Fiske Stone to Pierce Butler (Nov. 5, 1925), id. Stone believed that the Court mistakenly colored these acts with the contractor's "purpose... when he made the bid to do the construction work on the bridge, which would have been intrastate commerce whenever im the future he did it." Id. Stone's conclusion, therefore, was that the contractor, having engaged only in interstate commerce, was categorically immune from state sanction. 
Perhaps because Stone's perspective on judicial technique has become our own, ${ }^{400}$ we are tempted to perceive his proposed reorientation of dormant Commerce Clause doctrine as a form of realism. That may be because the alternative goal of categorically distinguishing domams of federal and state interests seems to us manifestly absurd. But the lesson of the intergovernmental tax immumity cases is that this objective was by no means quixotic to the Taft Court, which was fully prepared to go to elaborate lengths to attempt to achieve it. In domg so, the Taft Court was neither being formalist nor blindly adhering to rules. It was instead stubbornly seeking to preserve inherited ideals of dual sovereignty in the teeth of plainly altered circumstances.

\section{The Dormant Commerce Clause and Economic Rights}

Because the trope of "direct" burdens on interstate commerce was opaque and conclusory, it not infrequently also became a vehicle for the expression of substantive economic views that had hittle to do with the abstract architecture of dual sovereignty. The Taft Court was a very conservative institution, with an ingrained aversion to government regulation. As late as 1922, Taft was publicly complaining about the "disease of excessive legislation" that has "produced tons of statutory laws under which public money is wasted."

400. For an account of the creation of contemporary dormant Commerce Clause doctrine (in the guise of recuperating the "original" primciples of Cooley), see Robert L. Stern, The Problems of Yesteryear-Commerce and Due Process, 4 VAND. L. REV. 446, 451-60 (1951). For a discussion of the general triumph of Stone's version of judicial balancing, see T. Alexander Aleinikoff, Constitutional Law in the Age of Balancing, 96 YALE L.J. 943, 954 (1987). It is clear, however, that in particular contexts the principles of dual sovereignty retain a kind of vcstigial hold on contemporary conceptions of federalism. See, e.g., Roderick M. Hills, Jr., The Political Economy of Cooperative Federalism: Why State Autonomy Makes Sense and "Dutal Sovereignty" Doesn't, 96 MICH. L. REV. 813, 854 (1998):

The problem with the modern doctrine of state autonony is that, while the premises of such nationalistic dual federalism generally have been rejected by the Court in other doctrinal areas and completely rejected by national political practice, the doctrine of state autonomy has never really weaned itself from these origins.

Larry D. Kramer, Putting the Politics Back into the Political Safeguards of Federalism, 100 COLUM. L. REV. 215, 292 (2000) ("[M]any theories of federalism make the mistake of assuming an underlying ideal, permanent division of authority between the national government and the states: a substantive allocation that stands apart from and independent of the process by which this division is to be implemented."); Post \& Siegel, supra note 237, at 483-86 (noting the persistence of dual sovereignty themes in the Court's contemporary federalism decisions).

401. WILLIAM HOWARD TAFT, LIBERTY UNDER LAW: AN INTERFRETATION OF THE PRINCIPLES OF OUR CONSTITUTIONAL GOVERNMENT 41 (1922); see also WILLIAM HOWARD TAFT, REPRESENTATIVE GOVERNMENT IN THE UNITED STATES 10-13 (1921) lhereinaftcr TAFT, REPRESENTATIVE GOVERNMENT]. 
publicly cautioned that "there are certain fundamental social and economic laws which are beyond the power ... of official control, and any attempt to interfere with their operations inevitably ends in confusion, if not disaster." that people expect too much of the government." clude that Van Devanter, McReynolds, and Butler shared these sentiments. These views surely informed the Court's judgments about whether particular state requirements were too onerous to be tolerated by the national market and should accordingly be struck down as "direct" burdens. A Court generally suspicious of state interference witl private economic transactions might actually welcome a national "uniformity of governmental nonaction." "was

At times this hostility to government regulation assumed overtly constitutional dimensions. There are decisions, like Michigan Public Utilities Commission v. Duke, ${ }^{405}$ in which the Court's substantive due process jurisprudence plainly influenced its conclusions under the dormant Commerce Clause. In Duke, the Court struck down as apphied to an interstate trucker a Michigan statute that in essence required any person "transporting persons or property by notor vehicle for hire upon the public highways of the State" to become a common carrier. ${ }^{406}$ The Court's discussion is worth quoting at length:

This Court has held that, in the absence of national legislation covering the subject, a State may rightfully prescribe uniform regulations necessary for public safety and order in respect to the operation upon its highways of all motor vehicles-those moving in interstate commerce as well as others; that a reasonable, graduated hicense fee imposed by a State on motor vehicles used in interstate commerce does not constitute a direct burden on interstate coinmerce, and that a State, which, at its own expense, furnishes special facilities for the use of those engaged in intrastate and interstate commerce unay exact compensation therefor, and if the charges are reasonable and uniform, they constitute no burden on interstate

402. George Sutherland, Principle or Expedient?, in NEW YORK STATE BAR ASSOCIATION, PROCEEDINGS OF THE FORTY-FOURTH ANNUAL MEETING 262, 265 (1921).

403. Id. at 266.

404. See supra note 332 and accompanying text. The influence of political ideology on federalism jurisprudence is a staple of contemporary political science. See, e.g., Frank B. Cross \& Emerson H. Tiller, The Three Faces of Federalism: An Entpirical Assessment of Supreme Court Federalism Jurisprudence, 73 S. CAL L. REV. 741, 745-46 (2000) (arguing that political ideology, among other factors, contributes to the way individual Justices decide federalism cases).

405. 266 U.S. 570 (1925).

406. Id. at 574 . 
commerce. Such regulations are deemed to be reasonable and to affect interstate commerce only incidentally and indirectly. But it is well settled that a State has no power to fetter the right to carry on imterstate commerce within its borders by the imposition of conditions or regulations which are unnecessary and pass beyond the bounds of what is reasonable and suitable for the proper exercise of its powers in the field that belongs to it. One bound to furnish transportation to the public as a common carrier must serve all, up to the capacity of his facilities, without discrimination and for reasonable pay. The act would put on plaintiff the duty to use his trucks and other equipment as a common carrier in Michigan, and would prevent him from using them exclusively to perform his contracts. This is to take from him use of instrumentalities by means of which he carries on the interstate commerce im which he is engaged as a private carrier and so directly to burden and interfere with it. And it is a burden upon interstate commerce to impose on plaintiff the onerous duties and strict hability of common carrier, and the obligation of furnishing such indemnity bond to cover the automobile bodies hauled under his contracts as conditions precedent to his right to continue to carry them in interstate commerce. Clearly, these requirements have no relation to public safety or order in the use of motor vehicles upon the highways, or to the collection of compensation for the use of the highways. The police power does not extend so far. It must be held that, if applied to plaintiff and his business, the act would violate the commerce clause of the Constitution. ${ }^{40}$

To convert the interstate trucker into a common carrier would be to transform the ordinary property of his business into a form of property affected by the public interest. The Court was concerned to safeguard the trucker's liberty of contract, ${ }^{408}$ and this concern inanifestly propelled its conclusion that the Michigan statute constituted a direct burden on interstate commerce. The Court's substantive views about proper economic regulation were thus thoroughly intertwined with its

407. Id. at 576-77 (citations omitted).

408. Just so no one would miss the point, the Court devoted its penultimate paragraph to a brief statement of the conclusion that:

Moreover, it is beyond the power of the State by legislative fiat to convert property used exclusively in the business of a private carrier into a public utility, or to make the owner a public carrier, for that would be taking private property for public usc with. out just compensation, which no State can do consistently with the due process of law clause of the Fourteenth Amendinent.

Id. at 577-78. The Court devoted greater attention to the substantive due process point the following year in Frost \& Frost Trucking Co. v. Railroad Commission, 271 U.S. 583, 592 (1926) (holding that a private carrier cannot be transformed into a public entity by legislative cominand). 
structural judgment about the allocation of national and state
power.

409. A similar influence is also apparent in the Court's continuing hostility to North Dakota's efforts to regulate its grain market. In Lemke v. Farmers Grain Co., 258 U.S. 50 (1922), and then again in Shafer v. Farmers Grain Co., 268 U.S. 189 (1925), the Court struck down North Dakota statutes imposing uniform grading standards for grain, on the grounds that the grain was destined for shipment to other states and hence beyond the regulatory power of the state. For a discussion of these decisions, see BICKEL, supra note 103, at 164-201; Powell, supra note 391, at 472-75. Lemke and Shafer both rehed heavily on Bondurant, and were accordingly in deep tension in their account of interstate commerce with opinions like Heisler. See supra note 347 and accompanying text. Thus Thomas Reed Powell commented on the Lemke decision that "[i]t is not unlikely" that it, like Bondurant, "was influenced by a disrelish of the particular state requirement involved." Powell, supra note 134, at 499.

It should be noted that North Dakota legislation had long been the bete noir of conservatives. See, e.g., WILlIAM Howard TAFT, North Dakota Politics, in COLLECTEd EdTORIALS, supra note 18, at 509-12 ("There is much general interest in the politios of North Dakota, akin to that which there is in Russian affairs. North Dakota has been a laboratory for the trying out of novel political, social and economic experiments, and the people are paying the price."); Letter from Horace D. Taft to William Howard Taft (Feb. 19, 1921), Taft Papers, supra note 104, at Reel 224:

The North Dakota situation is very diverting. The North Dakota people will be like the boy who was kicked by the mule. You know his father told him he would never be so handsome again, but he would know a great deal more. All the votes in the world can't make bankers lend the money even at nine per cent.

James F. Vivian, "Not A Patriotic Party": William Howard Taft's Campaign Against the Nonpartisan League, 1920-1921, N.D. HisT., vol. 50, no. 4, at 4-10 (1983). Taft was in fact charged with defamatory falsehood for his hostile comments on the North Dakota Nonpartisan Leaguc, and he was forced to issue a public retraction. Mr. Taft Apologizes to Macdonald; Former President of the United States Withdraws Attack on Former State Official Elected by League, NONPARTISAN LEADER, Mar. 7, 1921, at 18; Mr. Taft Finds League Enemies Deceived Him, NONPARTISAN LEADER, Mar. 7, 1921, at 1 ("We want to thank Mr. Taft for the manly spirit he has shown in admitting his mistake."). Taft, lowever, persisted in his views, charging in his Janes Stokes Lectureship at New York University on April 30, 1921, that the Nonpartisan League

is not a patriotic American party. It has been made possible by the insistence of a number of unsuccessful and im many instances foreign born farmers in North Dakota, who were aroused by a real grievance, as to grain classification and rates, and who conceived the idea that through a political combination they could exclude every other class and every other interest and run the state for the farmers alone.

TAFT, REPRESENTATIVE GOVERNMENT, supra note 401, at 27-28; see also Democracy Losing Prestige, Says Taft, N.Y. TIMES, May 1, 1921, at 19; Taft Denounces Radical Paries, WASH. POST, May 1, 1921, at 7. Two days later, only a month before his nomination to be Chief Justice, Taft was attacked on the floor of the Senate for his hostihty to the League. 61 CoNG. REC. 91722 (1921) (statement of Sen. Ladd):

Ex-President Taft has during the past year gone out of his way repeatedly to cast reflections upon the farmers' aspirations as represented by the Nonpartisan League ..... It is clearly evident Mr. Taft knows very hittle of the real problems of the practical farmer who tills his own land, but has depended upon information largely furnished by that group who have for ages and in North Dakota for the past 40 years farmed the farmers, and from which group the tillers of the soil are determined to break away in their own orderly fashion and as loyal American citizens, not, as Mr. Taft would have you believe, as loodlums and anarchists. 
The Court's claim to supervise state police power under the dormant Commerce Clause is in this respect analogous to its claim to establislı a general federal common law in cases arising under its diversity jurisdiction. In botli areas the content of the Court's vision was intertwined witli its Due Process jurisprudence. ${ }^{410}$ And although the Court's pronouncements about the dormant Commerce Clause were subject to revision by congressional legislation, just as its conclusions about federal common law were subject to revision by state statutes, in each imstance the Court was able to fashion a highly consequential, conservative, and nationalizing jurisprudence that flourished in the interstices of legislative enactment.

\section{CONCLUDING THOUGHTS}

I began this Article by noting that the contemporary Court seems bent on resurrecting past notions of federalism. The image of resurrection is typically employed to signify a renewed commitment to state, as distimguished from national, power. Our survey of the federalism jurisprudence of the Taft Court, lowever, suggests that in the 1920s the Supreme Court was, on the whole, a highly nationalist institution. ${ }^{411}$ Like all sophisticated Americans, members of the Court fully appreciated the implications of World War I. They understood the importance of the national market and of having adequate national power to regulate and sustam that market. That is why the Court sanctioned appreciable expansions of congressional authority, and wliy it aggressively employed its own judicial power to weave a wide net of federal constitutional and common law rights designed to facilitate national economic integration.

The effects of the first World War, however, also included a vigorous backlasir against federal centralization. Throughout the 1920s, the nation mourned what it already regarded as the inevitable loss of the values of local self-government. When in the throes of this back-

The Nation even opposed Taft's appointment to the Court in part on the ground that "it must be perfectly plain that Mr. Taft will not be able to divest himself of an acquired prejudice in any case coming before him because of the activities" of the Nonpartisan League. The Chief Justice-A Mistaken Appointment, NATION, July 13, 1921, at 32.

410. E.g., BICKEL, supra note 103, at 165 . Bickel believed that the Court's use of the fcderahism values of the Commerce Clause to express "the same social and economic theories as in its Due Process decisions" ultimately "brought into disrepute the fair and hopeful idea of federalism," which was the Court's "gravest transgression.... By comparison the evil of the Court's due-process holdings may secm ephemeral." Id.

411. See, e.g., Larry D. Kramer, But When Exactly Was Judicially-Enforced Federalism “Born” In the First Place, 22 HARV. J.L. \& PUB. POL'Y. 123, 132 (1998). 
lash, the Taft Court would express its commitment to state authority through the ideological filter of dual sovereignty. The Court sought to preserve the possibility of decentralized power by defining and maintaining distinct spheres of state and federal authority. The purest example of this impulse may be found in the Court's jurisprudence of intergovernmental tax immunity, in which the Court strenuously sought to immunize both state and federal governments from the effects of the others' taxation. The doctrine ultimately collapsed, however, because the national economy had become so imtegrated that no such immunity was practically achievable. As the Taft Court redoubled its efforts to attain the impossible, it created a conceptual legal catastrophe.

An analogous pattern is visible in the Taft Court's efforts to develop dormant Commerce Clause doctrine. The ideology of dual sovereignty drove the Taft Court to separate what it regarded as the distinctly national sphere of interstate commerce from what it viewed as the distinctly local sphere of intrastate commerce. The idea, as Heisler suggests, was to protect the local authority of the states. But the very national economic integration that fueled the Taft Court's innovative jurisprudence of congressional commerce power also undermined the Court's ability to define and enforce a conceptually defensible distinction between interstate and intrastate commerce. The result was massive doctrinal incoherence. Additionally, and iromically, the Court's commitinent to national economic integration effectively functioned sharply to circumscribe the permissible reach of state power, thereby eviscerating the very local authority that dual sovereignty was designed to protect.

In the end, therefore, the principles of dual sovereignty, when applied to intergovernmental tax immunity or to the dormant Commerce Clause, both produced intellectual mcoherence and failed to protect state autonomy. It is no wonder that the ideology of dual sovereignty effectively disappeared from these doctrinal domains during the turmoil of the New Deal. In the decade of the 1920 s only one Justice foresaw this transformation and glimpsed how modern doctrine would develop. In both Metcalf and Di Santo, Stone proposed that the ideology of dual sovereignty be abandoned, and that state and federal power instead be conceived as essentially overlapping interests whose competing claims were to be balanced and assessed in hight of all relevant circumstances.

The inodern technique of balancing, however, explicitly abandons the comforting teleological reasoning of dual sovereignty. The 
Taft Court believed that there was an ideal paradigm of distributed federal and state power toward which constitutional adjudication could push governmental regulation. The lure of this paradigm pervaded the Taft Court's understanding of the value of federalism. But because the methodology of balancing explicitly repudiates any such teleological paradigm, the federahsm jurisprudence of the modern Court has been cut adrift, uncertain about how exactly it is supposed to weigh competing state and federal imterests. Techniques of balancing have thus remained mysterious, uninformed by any generally accepted theory of federalism capable of justifying an educated assessment of the relative force of federal and state concerns. Contemporary judges and scholars are even now searching for such a theory, which presently seems as elusive as in the 1920s.

Perhaps the most fascinating puzzle of the Taft Court's federalism lies in the question of why its evaluation of congressional power would occasionally trigger an apphcation of the primciples of dual sovereignty. Sometimes, as for example in its enforcement of federal antitrust law, the Taft Court was scrupulous to maintain a proper boundary between federal and state authority. But in other contexts, as for example im its support for federal railroad regulation, the Court was content to have national power almost entirely preempt the prerogatives of local control.

It is clear that the Taft Court's allegiance to dual sovereignty could in some circumstances be provoked by considerations of form. The Court was unwilling to cede to Congress broad power that would escape all judicial supervision. Thus the Court flatly refused to sanction federal taxing authority that was unlimited by considerations of congressional purpose, because any such authority would create essentially unrestricted federal police power. Conversely, the Court was more generous im its construction of federal authority when interpreting the scope of relatively narrow and discrete grants of power, such as the Spending Clause or the Eighteenth Amendment.

It is also clear, however, that the Taft Court's coinmitment to dual sovereignty could in other circuunstances be prompted by considerations of substance. The Court was willing to sanction highly intrusive congressional legislation exercised on behalf of a public inorahty that the Court conceived as expressing the common commitments of state and national constituencies. But the case was different when congressional Commerce Clause legislation was advanced in the naine of distinctively national interests. The national government was regarded in both popular and legal culture as especially inclined to 
slide into the position of an alien, managerial, and repressive bureaucracy, whereas states were seen as sites of local self-government. The Court thus grew downriglit suspicious when federal legislation threatened to restrict important constitutional rights, including the very rights wliose exercise the Court imagined as necessary for the success of local self-government.

The Court frequently conceived sucl rights in the distinctively economic terms characteristic of pre-New Deal substantive due process. Even if legislation regulating these rights might be constitutional if enacted by a state, the Court deployed structural considerations of federalisin to circumscribe their control by the national government, because the Court regarded federal restrictions as potentially more dangerous than otherwise identical state restrictions. That is why the Court's concern for principles of dual sovereignty was more likely to be triggered by federal regulations of ordimary contractual relationships, like tlose involved in antitrust law, than by federal regulations of property affected witl a public imterest, like those imphicated in railroad rate regulation.

If this analysis is correct, the Taft Court's jurisprudence of congressional power was underwritten by complex congeries of very specific historical perspectives, all of whicl were to be radically modified during the New Deal era. By the end of the 1930s, for example, the Court had virtually abandoned constitutional protections for economic riglts, thereby removing a cloud of suspicion from large stretclies of congressional regulation. The grave nationwide crisis of the Great Depression had effectively legitimated the federal government as the authentic voice of a genuine national deinocratic will, ${ }^{412}$ fulfilling the promise that progressives had long ago envisioned. ${ }^{413}$ Fears of a distant and imperial federal bureaucracy were thus pushed to the margins of popular and legal culture, diminishing the asymmetry between national and state legislation. Certainly by the conclusion of World War II there was less reason constitutionally to distrust national, as distinct from state, regulation.

Most fundamentally, the constitutional battles of the New Deal undercut the Court's understanding of itself as the authoritative voice of a deep public morality that transcended mere transient deinocratic

412. On the fascinating rhetorical construction of the depression as a serious national disaster, see Michele L. Landis, Fate, Responsibility, and "Natural" Disaster Relief: Narrating the American Welfare State, 33 LAw \& SoC’Y REV. 257, 280, 286-98 (1999).

413. See supra note 203 and accompanying text. 
will-an understanding that was ultimately rooted in the practice of common law adjudication. When enforcing federal common or constitutional law, the Court during the 1920s never imagined itself as implicated within the logic of dual sovereignty. Instead the Court envisioned itself as occupying an imaginative space that was somehow exempt from the coinpetitive tension between state and national authority.

The ferocious controversies of the New Deal foreclosed this strange, innocent, and transcendent space. The significance of the Court's embrace of Holmesian positivisin in Erie Railroad Co. v. Tompkins $^{414}$ lay precisely in the Court's renunciation of generalized moral authority in favor of the role of enforcing specifically federal law. This profound transformation carried significant implications even for the Court's ability to pronounce federal constitutional law. It would be no easy matter for a post-Erie Court sharply to distinguish between "public inorals" and a national democratic will. The Court's loss of traditional common law authority to speak for "the people" ineant that its constitutional jurisprudence would thereafter be pervasively dogged by challenges to its authority, inost commonly articulated in the form of the counterinajoritarian difficulty.

Taken together, these considerations strongly suggest that a modern Court cannot actually "revive" the federahism jurisprudence of the Taft Court. Pre-New Deal federalisin was inseparably tied to ideological formations that have long since dissipated. This can most plainly be seen in the context of the dormant Commerce Clause, where the Taft's Court's doctrine was, paradoxically, far more nationahstic than anything a contemporary Court would likely find acceptable. This nationalisin flowed directly froin the very framework of dual sovereignty that structured the entire subject of federalism. We cannot resurrect pre-New Deal federahisin without also resurrecting dual sovereignty. Yet the framework of dual sovereignty has utterly lost credibility in the specific contexts of both the dormant Commerce Clause and the doctrine of intergovernmental tax immuinity. In sucli circumstances, dual sovereignty is simply beyond redemption.

Even within the narrow context of congressional power, where the Rehnquist Court has displayed a vestigial attraction to principles

414. 304 U.S. 64 (1938). 
of dual sovereignty, ${ }^{415}$ the revival of pre-New Deal federalism is hardly a credible project. The Taft Court's suspicion of federal legislation was grounded simultaneously im a commitment to economic rights deemed essential to "the orderly pursuit of liappiness by free men" and in a brooding mistrust of Congress's capacity authentically to register a national democratic will, especially when compared to the Court's own legitimate role as a common law conservator of pubhic values. Neither concern can now be exphicitly embraced as a reliable guide to the limits of congressional power. It follows that if the Rehnquist Court is to resurrect limitations on congressional power that echo the dual sovereignty of an earlier era, it will have to propose and defend its very own theory of the "distimction between what is truly national and what is truly local." cifically contemporary account of the salient values of federalism.

415. For a discussion of the influence of this ideology on the federalism jurisprudence of the modern Court, see Post \& Siegel, supra note 237, at 483-86.

416. United States v. Morrison, 529 U.S. 598, 617-18 (2000). 
$* * *$

HeinOnline -- 51 Duke L.J. 1640 2001-2002 